\title{
1 Layered Double Hydroxides and LDH-derived materials in chosen environmental applications: a review
}

Keywords: Hydrotalcite, layered double hydroxides, materials, synthesis, applications, industrial, environmental.

\author{
Dylan Chaillot ${ }^{1,2}$, Simona Bennici, ${ }^{1,2,}$, Jocelyne Brendle $e^{1,2}$
}

${ }^{1}$ Université de Haute-Alsace, CNRS, IS2M UMR 7361, F-68100 Mulhouse, France

${ }^{2}$ Université de Strasbourg, France

*Corresponding author: simona.bennici@uha.fr 


\section{Introduction}

Layered double hydroxides, also called LDHs or anionic clays, are particular lamellar materials made of octahedral sheets composed of metallic cations in the center of the octahedra. These materials can be found in nature, and present the brucite $\left(\mathrm{Mg}(\mathrm{OH})_{2}\right)$ structure with divalent cations $\mathrm{M}^{\mathrm{II}}\left(\mathrm{Mg}^{2+}\right.$ or $\mathrm{Cu}^{2+}$ for example) partly substituted by trivalent cations $\mathrm{M}^{\mathrm{III}}$ (such as $\mathrm{Al}^{3+}$ or $\mathrm{Fe}^{3+}$. This partial substitution induces a positive charge deficit that is compensated by anions, such as carbonates, located in the interlayer space along with water molecules. The easily accessible interlayer is one of the sources of the anion exchange capacity of the compounds, and of its ability to capture and exchange anions. This characteristic is almost unique for inorganic materials, indeed clay minerals exhibit cation exchange capacity. Thanks to these characteristics, they are appreciated for their versatility, simplicity of tailoring and low cost. The general formula of LDHs can be described as follows:

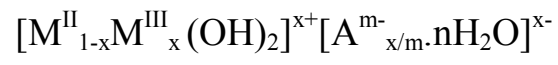

where $\mathrm{M}^{\mathrm{II}}$ and $\mathrm{M}^{\mathrm{III}}$ respectively represent the metallic divalent $\left(\mathrm{Mg}^{2+}, \mathrm{Cu}^{2+}, \mathrm{Zn}^{2+}\right)$ and trivalent $\left(\mathrm{Al}^{3+}, \mathrm{Fe}^{3+}\right)$ cations, $\mathrm{A}$ the compensating anion, and $\mathrm{x}$ and $\mathrm{m}$ depend on the substitution rate between $\mathrm{M}^{\mathrm{II}}$ and $\mathrm{M}^{\mathrm{III}}$ cations.

Hydrotalcites are particular LDHs (characterized by a Mg:Al molar ratio of 3:1) in which magnesium is partly substituted by aluminum . Specific properties such as porosity and surface area can be tailored by varying the synthesis method and conditions, leading to a wide range of materials adapted to targeted applications. The structure can also be modified by changing the combination of the cations and the interlayer anions, in order to confer specific properties, (Homsi et al. 2017; El Rouby et al. 2018; Sheng et al. 2019; Wu et al. 2019a).

LDHs can be synthesized by various techniques depending on the final requirements such as high crystallinity, low time and/or energy consuming reaction, and phase purity. The most common methods used to synthesize these materials are hydrolysis reaction, co-precipitation, 
hydrothermal synthesis, steam activation, microwave irradiation, and sol-gel. These fast and environmental-friendly synthesis processes, combined to high sorption capacities, allow the use of hydrotalcites and derived materials in various applications, such as adsorption of various molecules (organic and inorganic pollutants or dyes for example) or catalytic processes (also thanks to the presence of strong basic sites). In particular, these materials have been intensively studied as catalysts and catalyst supports based on their specific physicochemical features.

Mixed oxides, obtained from the calcination of the parent material, are most generally used in catalytic and environmental applications, due to the high temperatures required. The composition of the obtained oxides depend on the initial combination of $\mathrm{M}^{\mathrm{II}}$ and $\mathrm{M}^{\mathrm{III}}$ cations (El Rouby et al. 2018; Rahmanian et al. 2018; Sheng et al. 2019; Wu et al. 2019a), but also on the heating temperature and the targeted reaction (dehydration, dehydroxylation, removal of the interlayer anion, and oxide reformation). Considering the rising interest in using synthesized LDHs for various applications, this paper reviews the most common synthesis methods for their preparation and some chosen environmental applications (Fig1). Due to the wide panel of applications involving layered double hydroxides and LDH-derived materials, the list of applications here reported is not exhaustive. Moreover, certain applications have been already extensively reported in the literature and they could represent alone the subject of dedicated review articles (for example in the case of biodiesel production (Helwani et al. 2009; Atadashi et al. 2013)).

Abstract

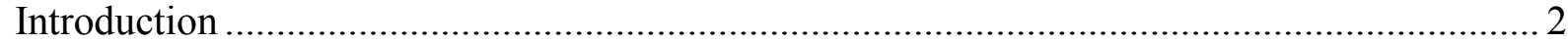

1. Synthesis techniques for hydrotalcite-like compounds................................................. 4

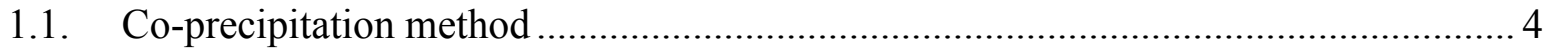

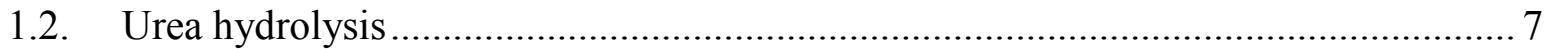

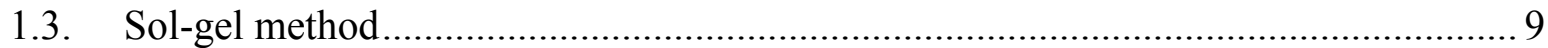

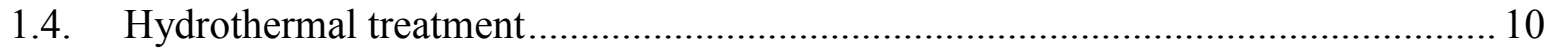


2. Use of hydrotalcites and derived materials in environmental applications

2.1. Adsorption of atmospheric pollutants

2.1.1. $\mathrm{CO}_{2}$ adsorption - Capture and storage

2.1.2. NOx and SOx adsorption

2.1.3. VOCs total decomposition 27

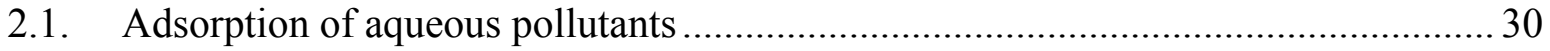

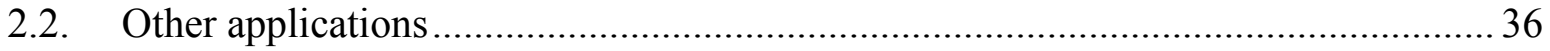

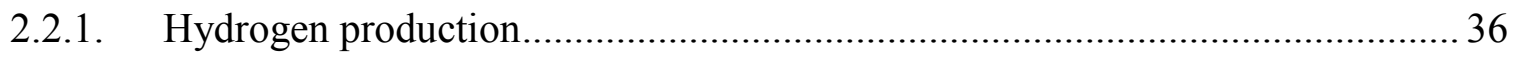

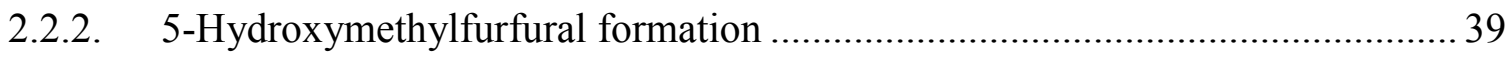

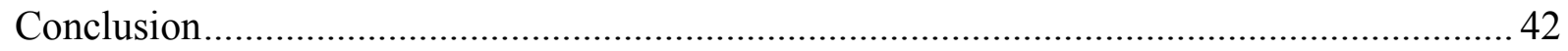

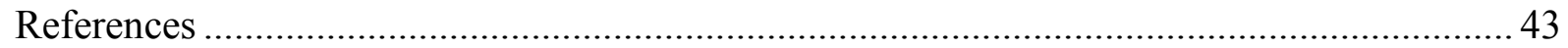

\section{Synthesis techniques for hydrotalcite-like compounds}

As previously explained, hydrotalcite (and more generally LDHs) can be of natural origin (alteration minerals) or synthetic. The advantages in synthesizing LDHs are the ability to finely tune the mineral properties in the view of a specific application, by finding the appropriate combination of reactants and the adapted $\mathrm{M}^{\mathrm{II}} / \mathrm{M}^{\mathrm{III}}$ molar ratio. The most important factors to be considered are the nature of the metallic cations, the $\mathrm{pH}$, the temperature, the ageing time, and the preparation method. Several synthesis methods have been developed during the last decades, but this review summarizes only those most commonly used and described in the literature.

\subsection{Co-precipitation method}

Co-precipitation is the most common method to synthesize LDHs. It consists in dissolving the inorganic salts in alkaline media, at constant or increasing $\mathrm{pH}$. This reaction allows to control the morphology and particle size, depending on the supersaturation of the solution. Feitknecht reported for the first time in 1942 on the LDH synthesis by co-precipitation. [Mg$\left.\mathrm{Al}-\mathrm{CO}_{3}\right] \mathrm{LDH}$ was synthesized starting from diluted solutions of the reactants. The coprecipitation synthesis process has been then studied years later by Gastuche et al. (1967) and 
Miyata $(1975,1980)$ by modifying parameters such as the concentrations of the reactants and the washing conditions. They also introduced the control of the $\mathrm{pH}$ as a key parameter for the formation of LDHs. Several studies have been performed later, focusing on the substitution of the type of metallic cations in the structure of the LDHs, as shown by Sato et al. (1988), in order to obtain several LDH with different structural formulas $\left(\mathrm{M}^{\mathrm{II}}=\mathrm{Mg}^{2+}, \mathrm{Ni}^{2+}\right.$ or $\mathrm{Co}^{2+}$ and $\mathrm{M}^{\mathrm{III}}=\mathrm{Al}^{3+}$ or $\left.\mathrm{Fe}^{3+}\right)$. Co-precipitation allows to finely tune the structure of the synthesized materials by controlling the $\mathrm{M}^{\mathrm{II}} / \mathrm{M}^{\mathrm{III}}$ molar ratios, the type of interlayer anion, the synthesis duration, the temperature, and the $\mathrm{pH}$ of the solution (Thevenot et al. 1989; Ulibarri 2001; Zhao et al. 2003; Kloprogge et al. 2004; Sharma et al. 2007; Klemkaite et al. 2011).

Co-precipitation can be performed at low or high supersaturation conditions depending on the desired crystallization state, as long as the initial concentration of the reactants is above the saturation state of the solution (supersaturation conditions). In any case, the $\mathrm{pH}$ of the solution must be controlled: a $\mathrm{pH}$ value too low does not allow the complete precipitation of all metallic ions, while a too high value leads to the leaching of one or more metallic ions. Basic media are preferred in most cases, but the optimal $\mathrm{pH}$ depends mainly on the metal cations used. Fig2. presents the steps involved in the co-precipitation synthesis process. The co-precipitation method performed at low supersaturation conditions has been firstly documented in the '90s by Kannan et al. (1995). This technique is performed by the slow addition of solutions containing the divalent and trivalent cations in the appropriate molar ratio, before adding an aqueous solution of the chosen interlayer anion (Kannan et al. 2004; Climent 2004; Kloprogge et al. 2004; Kovanda et al. 2005a; Perez-Lopez et al. 2006; Sharma et al. 2007; Wang et al. 2011; Klemkaite et al. 2011; Balsamo et al. 2012). An alkaline solution is then added in order to fix the $\mathrm{pH}$ during the reaction and to promote the coprecipitation of the two metal salts. This synthesis process has been well described by a schematic flow chart edited by El Rouby et al. (2018). The advantage of this method is the 
possibility to control the charge density by keeping the $\mathrm{pH}$ constant under low supersaturation conditions by the addition of a mixture of $\mathrm{NaOH}$ and $\mathrm{NaHCO}_{3}$ or $\mathrm{Na}_{2} \mathrm{CO}_{3}$ (Sharma et al. 2007; Wang et al. 2011; Klemkaite et al. 2011; Balsamo et al. 2012; Sheng et al. 2019; Li et al. 2019a). Materials obtained by co-precipitation at low supersaturation present a higher crystallinity than those obtained at high supersaturation conditions thanks to the continuous regulation of the $\mathrm{pH}$ of the synthesis solution. In the high supersaturation condition, the concentration of the solutions is continuously increased or the solution containing the dissolved salts is added to a solution containing a small excess of alkali bicarbonates. This process leads to the formation of less crystalline materials than low supersaturation method, but gives rise to a high number of small aggregates due to the interlayer confinement effect of the carbonate ions (Zhang et al. 2008; Abelló et al. 2010; Solovov et al. 2018).

Co-precipitation synthesis can be considered as an efficient method to obtain crystalline materials, particularly thanks to the long synthesis duration time (several days), the controlled synthesis $\mathrm{pH}$, and the addition of post treatments such as hydrothermal treatment for example (Kannan et al. 1995; Kloprogge et al. 2004). However, due to the large dimension of the obtained particles the specific surface area values (between $50-100 \mathrm{~m}^{2} \cdot \mathrm{g}^{-1}$ ) are lower than those obtained by sol-gel synthesis $\left(150-200 \mathrm{~m}^{2} \cdot \mathrm{g}^{-1}\right)$, and discussed later in this review (Aramendía 2002; Park et al. 2018). The substitution with other metallic cations, such as Fe, $\mathrm{Zn}, \mathrm{Cu}$, and $\mathrm{Ni}$, as demonstrated by Gevers et al. (2019), add the possibility to modify the crystallite dimensions and influence the thermal stability of LDHs. Thermal treatments, such as hydrothermal treatment or microwave irradiation, can be performed to improve crystallinity and/or to reduce the synthesis time. Similar structures are then obtain even with shorter synthesis time (Climent 2004). This progress was reported by Tichit et al. (2002) by comparing microwave and hydrothermal treatments in co-precipitated hydrotalcites. The authors did not find any significant differences in the structural properties of the final 
material, despite the shorter synthesis time that represent a clear advantage. The thermal treatment presents a significant impact on the structural properties of the materials: Othman et al. (2006) compared the effect of the hydrothermal treatment on hydrotalcites prepared by coprecipitation and sol-gel methods. They showed that the specific surface area and pore sizes significantly increased in both cases, with a stronger impact on the samples synthesized by sol-gel.

\subsection{Urea hydrolysis}

Urea is a weak Brönsted base highly soluble in water. It can be used as a precipitating agent instead of sodium hydroxide to increase the $\mathrm{pH}$ through its thermal decomposition. The slow decomposition, starting around $90^{\circ} \mathrm{C}$, leads to an increase of the $\mathrm{pH}$ up to 10 (Costantino et al. 1998; Yang et al. 2004). Since urea decomposes slowly, it leads to a lower degree of supersaturation. Moreover, prolonged hydrolysis results in the formation of $\mathrm{CO}_{3}{ }^{2-}$ anions in basic medium that act as interlayer anions. Therefore, urea enables an efficient $\mathrm{pH}$ control and the formation of mono-dispersed LDH materials with high crystallinity through a low-cost method (Adachi-Pagano et al. 2003; Yang et al. 2004; Zeng et al. 2009a; Xu et al. 2016; Park et al. 2018). The purity and crystallinity of hydrotalcite phases can also be optimized by tuning the $\mathrm{M}^{\mathrm{II}}: \mathrm{M}^{\mathrm{III}}$ molar ratio, the urea concentration, and the ageing time (Costantino et al. 1998; Zeng et al. 2009a; Berber et al. 2013; Montañez et al. 2014; Zhang et al. 2014; Bian et al. 2016; Xu et al. 2016; Park et al. 2018). As an exemple, Berber et al. (2013) identified the optimal synthesis conditions to obtain uniform and highly crystalline hydrotalcite particles by using a urea/metallic cation molar ratio of 2 , and $12 \mathrm{~h}$ of ageing time at $120^{\circ} \mathrm{C}$. Secondary phases have been observed with molar ratios lower or greater than 2, leading to lower crystallinity and specific surface areas of the materials. The main steps involved in hydrotalcite synthesis via urea hydrolysis are summarized in Fig3. 
Most of the time, this technique is combined to others (in which urea is used only as a precipitating agent), such as co-precipitation or hydrothermal synthesis. The combination of urea hydrolysis and hydrothermal treatment has been well-documented by Berber et al. (2013) and Benito et al. (2006) in order to obtain uniform particles, but also by Rao et al. (2005) to find optimal Mg:Al molar ratios of 1:1 and 2:1 with uniform and small particles' size. In the first article, microwave irradiation was used as heating source in the synthesis process, strongly shortening the synthesis time and the formation of pure and well-crystallized hydrotalcite phases presenting high specific surface areas. Further studies were performed by Montañez et al. (2014) by comparing the properties of mixed oxides obtained by calcination of a series of Ni-Al-Mg hydrotalcites synthesized, either by co-precipitation or by urea hydrolysis. Enhanced redox properties, larger pore sizes and smaller particles (interesting features in catalytic applications) were obtained on calcined samples prepared with urea hydrolysis. In general, the use of microwave irradiation allows to reduce the preparation time without to impact on the structural and physical properties. This methodology is of a great interest for the industrial scaling-up (Yang et al. 2007; Benito et al. 2008). Hibino and Ohya. (2009) combined urea hydrolysis with hydrothermal treatment in order to remove certain byproducts (i.e. hydrated magnesium carbonate hydroxide phases). Further studies have been performed by Kloprogge et al. (2006) to show the evolution of the intercalated species depending on the hydrothermal treatment: $\left(\mathrm{NH}_{2}\right) \mathrm{COO}^{-}$tends to directly form after precipitation, but slowly transforms into carbonated species during the hydrothermal treatment.

As a partial conclusion, urea hydrolysis is a slow reaction that leads to a low degree of supersaturation during the precipitation. It presents the advantage to provide large and thin platelets with a narrow particle size distribution in a shorter ageing time than co-precipitation (Naseem et al. 2019). However, the decomposition of urea leads to the formation of $\mathrm{CO}_{2}$ that 
reacts with water to form carbonates and acting as compensating anions (Thomas 2012). In this case, a further anion exchange may be required depending on the targeted application (Bish 1980; Iyi et al. 2004; Inayat et al. 2011).

\subsection{Sol-gel method}

The sol-gel method is appreciated for its low cost, low energy and limited time consuming, for the possibility to obtain high purity materials, and for the possibility to tune their composition (Lopez et al. 1996; Paredes et al. 2006; Sharma et al. 2007; Ramos-Ramírez et al. 2009; Lee et al. 2016). This process allows to control the structural properties of the final materials by simply varying the chemical nature of the reactants, the ageing time, and by removing/adding reactant species. This technique consists in dissolving the desired metal sources (inorganic salts or metal organic compounds) in water, at room temperature (Fig4.).

The concentration of the metal cations can be varied to tune the substitution ratio of $\mathrm{M}^{\mathrm{II}}$ and $\mathrm{M}^{\mathrm{III}}$ cations and to obtain a wide range of materials (Corma et al. 1994; Valente et al. 2007, 2009; Sharma et al. 2007). The appropriate amount of acid or base is then added to the reactants' solution during hydrolysis to favor the condensation reaction. The solution is finally aged during several hours or days, at room temperature or lightly heated up to $100^{\circ} \mathrm{C}$. Prince et al. (2009) proposed a general sol-gel method for the preparation of LDHs that can be adapted to obtain materials containing specific metallic cations and possessing a defined morphology in the view of a specific application. Ramos-Ramirez et al. (2009) also evidenced the formation of small amounts of brucite phase, in addition to hydrotalcite, with a $\mathrm{Mg} / \mathrm{Al}$ molar ratio of 2 and explained this behavior by the similar structure of the two materials. Synthetic hydrotalcites can also be calcined and rehydrated without losing their lamellar structure. During regeneration, they show a "memory effect", as evidenced by Climent et al. (2004) by using rehydrated sol-gel hydrotalcites for pharmaceutical applications. 
Several parameters can be varied to improve the crystallinity (Kovanda et al. 2005b;

Valente et al. 2009) of the particles, to modify their morphology (Valente et al. 2007, 2009, 2010), and to enhance the surface area (Corma et al. 1994; Lopez et al. 1996, 1997a; Climent et al. 2004; Paredes et al. 2006; Valente et al. 2007; Prince et al. 2009). Parameters, as the composition of the aqueous media, the $\mathrm{pH}$, and the ageing time, were considered (Corma et al. 1994; Kovanda et al. 2005b). Lopez et al. (1997b) studied the impact of different alkoxides, such as magnesium $\left(\mathrm{Mg}(\mathrm{OEt})_{2}\right)$ and aluminum $\left(\mathrm{Al}\left(\mathrm{NO}_{3}\right)_{3}\right)$, used as reactants, on the thermal stability of a series of hydrotalcites. Most of the time, the comparison between the synthesis techniques and the parameters evidences the interest of using one or the other specific method, generally sol-gel or co-precipitation (Jitianu et al. 2000; Prinetto et al. 2000; Bolognini et al. 2003; Othman et al. 2006; Valente et al. 2007, 2010; Smalenskaite et al. 2017). Smalenskaite et al. (2017) compared sol-gel and co-precipitation for the preparation of cerium-substituted Mg-Al LDHs; Othman et al.(2006) studied the impact of the thermal treatment on the structure of similar materials. In many cases, the sol-gel approach is preferred for its simplicity and the high quality of the materials obtained (Ramos et al. 1997; Othman et al. 2006; Valente et al. 2010; Lee et al. 2016; Smalenskaite et al. 2017).

The sol-gel synthesis method is appreciated for its high reproducibility, the high homogeneity and purity of the obtained compounds, the small size of the particles (nanoscale) and their high specific surface area (Prince et al. 2009; Smalenskaite et al. 2017; Valeikiene et al. 2019). However, lower crystallinity is generally observed through this synthesis route (Smalenskaite et al. 2017). Often and depending on the final application of the materials, additional steps such as sonication, microwave irradiation (Benito et al. 2006) or hydrothermal treatment are required.

\subsection{Hydrothermal treatment}


As previously reported, the synthesis of LDHs by co-precipitation, sol-gel method or urea

hydrolysis can be optimized by hydrothermal treatment in order to improve the crystallinity and the size of the crystallites (Kloprogge et al. 2004; Sharma et al. 2007). The treatment generally occurs under mild hydrothermal conditions, up to $200^{\circ} \mathrm{C}$, autogenous pressure, with durations between hours to several days. Fig5. displays the hydrothermal synthesis process.

Besides the improvement of the crystallinity, hydrothermal synthesis can be directly used as a synthesis method, in order to form LDH phases with increased particle sizes. It consists in dissolving the metallic salts into a solvent (generally water) before putting the solution into a stainless-steel reactor and heating under hydrothermal conditions, generally under medium temperatures $\left(30-300^{\circ} \mathrm{C}\right)$ and steam pressure, with different synthesis times (few hours to several days) (Xu and Lu 2005; Liao et al. 2012; Bontchev et al. 2003; Bankauskaite and Baltakys 2011; Lin et al. 2019; Budhysutanto et al. 2010; Roelofs et al. 2001; Jang et al. 2014). Several reactants such as inorganic salts and minerals can be used as metal sources. Most commonly, metal oxides and hydroxides (Xu and Lu 2005; Budhysutanto et al. 2010; Jang et al. 2014; Labuschagné et al. 2018) or nitrate salts (Roelofs et al. 2001; Bontchev et al. 2003; Lin et al. 2019) are used as reactants, but other sources can be used: Ogawa et Asai (2000) used for example natural minerals (brucite and gibbsite) as starting materials to intercalate organic guests. Liao et al. (2012) also used natural brucite and $\mathrm{Al}(\mathrm{OH})_{3}$ as synthesis reactants to study the morphology and structural properties of hydrotalcites obtained under different synthesis conditions.

Like for the other synthesis techniques, the $\mathrm{Mg}$ :Al molar ratio and the interlayer anions can be modified in order to obtain a wide range of hydrotalcites and LDHs with different structural properties. Bontchev et al. (2003) studied the impact of several interlayer anions $\left(\mathrm{Cl}^{-}, \mathrm{Br}^{-}, \mathrm{I}^{-}, \mathrm{NO}_{3}{ }^{-}\right)$on the physico-chemical characteristics of hydrotalcites. Moreover, this study showed the possibility to mix two different types of compensating anions to finely tune 
the properties of these compounds. The hydrothermal synthesis of hydrotalcites with different soluble and insoluble magnesium and aluminum reactants in water has been studied by Bankauskaite and Baltakys (2011), with a fixed Mg:Al molar ratio of 3:1. The non-formation of hydrotalcite phases was observed in the presence of certain reactants. It was demonstrated that alumina and magnesium aluminum hydroxide were preferentially formed when using $4 \mathrm{MgCO}_{3} \cdot \mathrm{Mg}(\mathrm{OH})_{2} \cdot 5 \mathrm{H}_{2} \mathrm{O}$, even after $24 \mathrm{~h}$ of hydrothermal treatment at $200^{\circ} \mathrm{C}$. The choice of the appropriate metal salts is the most important parameter to be considered. More recently, the impact of the synthesis temperature (from 35 to $140^{\circ} \mathrm{C}$ ) has been tested by Lin et al. (2019) to synthesize CuZnAl hydrotalcite-like catalysts for arsine abatement. The authors concluded on a significant influence of the synthesis conditions on the arsine removal efficiency without clear explanation. The problem comes from the multiplicity of the parameters varied during the synthesis of the catalysts (temperature, calcination, time, molar ratios), making the results difficult to interpret. The most recent studies focus on the green synthesis of hydrotalcites and derived materials for environmental concerns, as demonstrated by Labuschagné et al. (2018) by using untreated magnesium oxide and aluminum hydroxide for hydrothermal dissolution/precipitation in water.

The advantages of using this synthesis process as additional treatment are the higher LDH crystallinity, crystallites dimension, and purity of the samples (Kovanda et al. 2005b; Sharma et al. 2007). In general, a higher content of hydrotalcite is observed by increasing the preparation temperature and the time of the hydrothermal treatment (Kovanda et al. 2005b). Unfortunately, the energy required to heat-up the solution and the long synthesis time (from hours to days) represent drawbacks for the industrial implementation of the hydrothermal treatment. 
The recent advancements and progresses on the synthesis methodologies have been reviewed in this section. Moreover, each synthesis method has been detailed in order to enlighten the advantages and drawbacks in terms of structural and textural properties. The modulation of these features is crucial to drive the performances towards specific environmental and industrial applications. Table 1 lists the positive and negative impacts of the various synthesis routes on the structural and textural properties of LDHs.

\section{Use of hydrotalcites and derived materials in environmental applications}

The depletion of fossil fuels and their environmental impacts (global warming, pollution, health concerns...) are currently boosting the studies on alternative solutions and clean synthetic routes for the production of non-fossil carbon sources. Recent international conventions agreed to the Kyoto Protocol and intended to reduce by 2050 the global emissions up to $50-60 \%$ (of those measured in 2006). The necessity in finding alternative environmental applications based on easy-to-use materials becomes more than urgent. Several reactions can be performed on layered materials, but their low thermal stability makes their implementation difficult. Clay minerals are generally stable up to $200^{\circ} \mathrm{C}$ due to the loss of the interlayer water and the consequent irreversible degradation of the structure at temperatures higher than $200^{\circ} \mathrm{C}$. The presence of specific metal elements in the structure of the LDHs can enhance their catalytic properties, depending on the applications, as mentioned by $\mathrm{Xu}$ et al. (2011). Moreover, due to their composition (mainly metallic cations), LDHs can be calcined to form mixed oxides presenting enhanced catalytic properties. Even if much more environmental related processes can be carried out in presence of lamellar materials, only few of them are discussed in this review. Some specific environmental application covering various technological fields have been chosen to be reported in the present review article such as the adsorption/decomposition of gaseous pollutants $\left(\mathrm{CO}_{2}, \mathrm{NOx}\right.$, and SOx adsorption, and 
elimination of VOCs), the adsorption of pollutants in aqueous media (as the adsorption of heavy metals and dyes), and the production of green energy vectors and/or chemical building blocks (hydrogen production and formation of 5-hydroxymethylfurfural).

\subsection{Adsorption of atmospheric pollutants}

\subsection{1. $\mathrm{CO}_{2}$ adsorption - Capture and storage}

Among the possible uses of hydrotalcite-like compounds and their derived mixed-oxides, $\mathrm{CO}_{2}$ adsorption gains interest. Methods for safely control and dispose of carbon dioxide emissions are widely studied in the last few years, mainly due to the increase of consciousness in climate changes (Wang et al. 2017). Among all the emitted greenhouse gases, the contribution of carbon dioxide to global warming has been estimated to more than $60 \%$. For example, steam reforming of hydrocarbons (Marquevich et al. 2001; Ashok et al. 2008; Li et al. 2011), that is the most suitable process for hydrogen production, releases high amounts of carbon dioxide. Considering the large field of materials tested for $\mathrm{CO}_{2}$ capture and storage, zeolites, hydrotalcite and LDH-derived mixed oxides are widely studied thanks to their high surface area, pore structure, and charge density (Mao and Tamaura 1993; Tsuji et al. 1993; Yong et al. 2002; Wang et al. 2010; Dantas et al. 2015; Yang et al. 2019). Several reviews on $\mathrm{CO}_{2}$ adsorption explain that an appropriate adsorbent should satisfy several criteria such as (1) low-cost materials, (2) fast kinetics, (3) high adsorption capacity and selectivity, and (4) thermal and chemical stability towards several cycles (Yong et al. 2002; León et al. 2010; Wang et al. 2017; Yang et al. 2019). The adsorption of $\mathrm{CO}_{2}$ requires materials with large specific surface area, but also a high number of accessible basic sites. Regarding the synthesis method adapted to this application, a high number of active sites and large particles are required for better adsorption efficiency. Thus, the co-precipitation method represents the best solution to reach these requirements, especially when the LDHs structure is modified by the 
addition of metal cations. The higher the energy of active sites, the stronger $\mathrm{CO}_{2}$ interacts with the sites and remains trapped. Recently, zeolites are reported as efficient $\mathrm{CO}_{2}$ adsorbents thanks to their size, charge density, and tunable chemical composition (Jiang et al. 2018; Yu et al. 2018). Hydrotalcite-based materials are thereby interesting alternative materials to zeolites, as their chemical composition can also be finely tuned. $\mathrm{CO}_{2}$ adsorption performed on these materials is a natural phenomenon, as hydrotalcite can adsorb carbon dioxide thanks to the reaction of atmospheric $\mathrm{CO}_{2}$ with the compensating ions present in the interlayer space. This has been evidenced by Ishihara et al. (2013) by intercalating ${ }^{13} \mathrm{C}$ carbonate anions in the hydrotalcite structure. They were exchanged with carbonate anions derived from atmospheric $\mathrm{CO}_{2}$ within 1 day, showing the dynamism of the carbon cycle in nature. Moreover, these materials can be regenerated several times, without losing their adsorption capacity and selectivity towards $\mathrm{CO}_{2}$, are hydrothermally stable, and lead to fast sorption kinetics. A huge amount of studies has been performed on these materials in order to find the most efficient preparation route for $\mathrm{CO}_{2}$ capture, such as impregnation of commercial hydrotalcites (Bhatta et al. 2015), synthesis of tunable Mg/Al hydrotalcites (Tsuji et al. 1993; Moreira et al. 2006; Dantas et al. 2015), and mixed oxides derived from hydrotalcites (León et al. 2010; Gao et al. 2013; Radha and Navrotsky 2014; Colonna et al. 2018). Table 2 summarizes the synthesis conditions, the specific surface area, and the $\mathrm{CO}_{2}$ adsorption capacity of the LDHs and related mixed oxides. It shows that the surface area is strongly linked to the $\mathrm{CO}_{2}$ adsorption capacity: a higher surface area is related to an increase in the sorption capacity.

The preliminary studies of $\mathrm{CO}_{2}$ adsorption by hydrotalcite, layered double hydroxides and related materials have been performed by Mao and Tamaura (1993) by varying the $\mathrm{M}(\mathrm{II}) / \mathrm{M}(\mathrm{III})$ molar ratio and consequently the layer charge of the synthesized hydrotalcites. The composition tuning resulted in a wide range of materials capable of chemically adsorb $\mathrm{CO}_{2}$ with different adsorption capacities (from 0.4 to $1.5 \mathrm{mmol} . \mathrm{g}^{-1}$ ). The same year, Tsuji et 
al. (1993) synthesized various LDHs by changing the M(II) cation nature. The selectivity

381 towards carbon dioxide adsorption depended on the cation in the following order: $\mathrm{Cu}-\mathrm{Al} \sim$ $\mathrm{Zn}-\mathrm{Al}<\mathrm{Co}-\mathrm{Al}<\mathrm{Mg}-\mathrm{Al}<\mathrm{Ni}-\mathrm{Al}$, and was related to the thermal behavior of the various compounds. Moreover, the sorption capacities of these materials have been drastically increased by removing the carbonate counterions in the $\mathrm{Mg}-\mathrm{Al}$ and $\mathrm{Co}-\mathrm{Al} \mathrm{LDHs}$. Several years later Wang et al. (2010) studied substitution of divalent metal cations M(II) by trivalent metal cations $\mathrm{M}(\mathrm{III})\left(\mathrm{Al}^{3+}, \mathrm{Ga}^{3+}, \mathrm{Fe}^{3+}\right.$ and $\left.\mathrm{Mn}^{3+}\right)$ in $\mathrm{CO}_{2}$ adsorption at high temperature, performed on calcined samples.

Few years after Tsuji et al. (1993), the studies about $\mathrm{CO}_{2}$ adsorption were mainly focused on industrial applications and enlightened the influence of structural parameters derived from the thermal treatment of LDHs, leading to the formation of related mixed oxides. Ram Reddy et al. (2006) showed that, depending on the applied treatment temperature, the samples exhibited different sorption capacities and reversibility. The highest sorption capacities were observed on samples pretreated at $400^{\circ} \mathrm{C}$ and a sorption temperature of $200^{\circ} \mathrm{C}$, leading to $\mathrm{CO}_{2}$ adsorption of $0.486 \mathrm{mmol} . \mathrm{g}^{-1}$. The pretreatment conditions showed also an impact on the regeneration behavior (cycling studies). Two years later, the same team (Ram Reddy et al. 2008) studied high-temperature $\mathrm{CO}_{2}$ adsorption in industrial conditions. An increase of the sorption efficiency was observed, from 0.61 to $0.71 \mathrm{mmol} . \mathrm{g}^{-1}$, in presence of dry and wet $\mathrm{CO}_{2}$ respectively, with more than $90 \%$ of the original capacity recovered by regeneration. Dadwahl et al. (2008) reported on the influence of the particle size on $\mathrm{CO}_{2}$ adsorption, and analyzed the formation of large particles by co-precipitation. Mixed oxides generally exhibit higher sorption capacities due to the higher specific surface area than the fresh samples, but the analysis conditions (sorption temperature, mixture of gas, etc...) affect the $\mathrm{CO}_{2}$ adsorption capacities in the same way than on non-calcined samples, as demonstrated by León et al. (2010). The obtained capacities, in the $0.58-1.15 \mathrm{mmol} \cdot \mathrm{g}^{-1}$ range at $50^{\circ} \mathrm{C}$, and $0.40-0.84$ 
mmol.g ${ }^{-1}$ range at $100^{\circ} \mathrm{C}$, depend on the pretreatment temperature, 450 or $700^{\circ} \mathrm{C}$ respectively. Regarding the reversibility of these materials, the co-precipitation method at high supersaturation conditions is more adapted than that at low supersaturation, due to the formation of weaker basic sites for the latter. As previously explained, Wang et al. (2010) studied the influence of $\mathrm{M}(\mathrm{III})$ cation type towards high-temperature $\mathrm{CO}_{2}$ adsorption on calcined samples at different temperatures, from 250 to $400^{\circ} \mathrm{C}$. Different phases have been observed depending on the calcination temperature: $\mathrm{MgFe}_{2} \mathrm{O}_{4}$ and $\mathrm{MgMnO}_{4}$ with coexistence of $\mathrm{MgO}$ with the appropriate $\mathrm{M}(\mathrm{III})$ cations, whereas only $\mathrm{MgO}$ phases have been observed in MgAl and MgGa LDHs. Moreover, the M(III) cation nature did not affect the sorption capacity (around $0.4 \mathrm{mmol} . \mathrm{g}^{-1}$ ), except for the calcined MgGa LDH that gave lower values of $\mathrm{CO}_{2}$ sorption capacity due to its lower thermal stability. Gao et al. (2013) discovered the optimal parameters to obtain hydrotalcites with improved $\mathrm{CO}_{2}$ adsorption capacity: synthesis by co-precipitation method, at high supersaturation conditions, with a $\mathrm{Mg} / \mathrm{Al}$ molar ratio between 3 and 3.5 , and a pre-calcination temperature of $400^{\circ} \mathrm{C}$ (The $\mathrm{CO}_{2}$ adsorption measurements were performed during 5 hours at $200^{\circ} \mathrm{C}$ ). The operating conditions (temperature and pressure) impact the adsorption capacity of $\mathrm{CO}_{2}$ too: Ramirez-Moreno et al. (2014) stated that high pressures (up to $4350 \mathrm{kPa}$ ) and temperatures $\left(30-350^{\circ} \mathrm{C}\right.$ ) are related to higher $\mathrm{CO}_{2}$ adsorption levels, with a maximum value of $5.76 \mathrm{mmol} . \mathrm{g}^{-1}$ measured at $300^{\circ} \mathrm{C}$ and $3450 \mathrm{kPa}$. Higher values can be reached at higher temperatures and pressures, and related to structural changes in the LDHs framework (formation of magnesium oxides and periclase for example).

The most recent researches focus on modifications of the structure of LDHs synthesized by co-precipitation in order to increase their $\mathrm{CO}_{2}$ adsorption capacity. Similar to simple ionexchange reaction, the potassium impregnation consists in putting the synthesized materials into a solution with a defined concentration of potassium salt during few hours, followed by 
the washing of the salt excess. $\mathrm{K}_{2} \mathrm{CO}_{3}$ impregnation seems to increase the number of surface

431 active sites despite a decrease in the specific surface area. This impregnation leads to high 432 adsorption capacities, as demonstrated by Bhatta et al. (2015): values up to $1.10 \mathrm{mmol} \cdot \mathrm{g}^{-1}$ at

433

$300^{\circ} \mathrm{C}$ for the initial sorption cycle, and of $0.42 \mathrm{mmol.g}{ }^{-1}$ for the following 9 cycles of adsorption/desorption were measured. Polymers addition can modify the textural properties of layered materials and contribute to the enhancement of the $\mathrm{CO}_{2}$ sorption capacity, as showed by Dantas et al. (2015) by the addition of a co-polymer that increased the $\mathrm{CO}_{2}$ uptake from 0.72 to 1.36 mmol.g ${ }^{-1}$. Tang et al. (2018) increased the basal spacing of LDHs by exchanging anions with dodecylsulfonate ions in order to chemically graft (3-aminopropyl)triethoxysilane (APS) and enhance the $\mathrm{CO}_{2}$ sorption capacity (up to $2.09 \mathrm{mmol} \cdot \mathrm{g}^{-1}$ at $50^{\circ} \mathrm{C}$ ). The presence of amino groups in the interlamellar space strongly contributed to the capture of carbon dioxide through the zwitterion mechanism and weak bonding. By optimizing the synthesis parameters, Thouchprasitchaia et al. (2018) obtained a series of calcined teraethylenepentamine (TEPA)supported hydrotalcites. At first, increasing the TEPA loading led to higher adsorption capacities, explained by the availability of more basic sites with a higher affinity for $\mathrm{CO}_{2}$. A too high TEPA content resulted in the decrease of the sorption capacity due to the steric hindrance of TEPA that blocks the access of $\mathrm{CO}_{2}$ to the sorption sites.

Among the large panel of industrial applications, sorption enhanced reactions processes (SERP) gained huge interest in the last decade, especially thanks to novel modifications introduced into LDHs structure. SERPs have been developed for the efficient conversion of methane to hydrogen. The main drawback of this process is the formation and release of large amounts of $\mathrm{CO}_{2}$, then materials with high carbon dioxide sorption capacity are crucial for this application. The first amine modifications of $\mathrm{LDHs}$ for $\mathrm{CO}_{2}$ adsorption performance towards SERP applications have been performed by Wang et al. (2012b, a) via two different routes: anionic surfactant-mediated synthesis and exfoliation. In the first case, low $\mathrm{CO}_{2}$ adsorption 
capacities (up to $0.6 \mathrm{mmol} . \mathrm{g}^{-1}$ ) have been recorded, mainly due to the presence of Sodium Dodecyl Sulfate (SDS) in the interlayer space. SDS can be then removed using monoethylamine extraction (ion exchange reaction), leading to higher sorption values (between 1.15 and 1.4 mmol.g ${ }^{-1}$ ) (Fig6.). On the opposite, the exfoliation route in the presence of toluene allows to graft amine groups on the surface of LDHs giving high sorption capacities towards $\mathrm{CO}_{2}$ (around $1.7 \mathrm{mmol} \cdot \mathrm{g}^{-1}$ at $80^{\circ} \mathrm{C}$ ). The two studies underline the importance of the interlayer space in LDHs: sodium dodecyl sulfate and aminosilanes molecules present in this area cover the main part of the basic sites involved in the $\mathrm{CO}_{2}$ adsorption, consequently lowering the sorption capacity. It is important to consider the steric hindrance when considering lamellar materials. Most of the time, K-promoted hydrotalcites are interesting adsorbents in SERP, as the potassium presence leads to sorption capacities higher than $1 \mathrm{mmol} \cdot \mathrm{g}^{-1}$, as demonstrated by $\mathrm{Wu}$ et al. (2013). Moreover, the adsorption capacity and kinetics were not affected even after 10 cycles, which is interesting for SERP applications. Coenen et al. (2017b, a) also published about K-promoted hydrotalcites in a series of publications for sorption-enhanced water-gas shift. This article points out the importance of chemisorbed $\mathrm{CO}_{2}$ and $\mathrm{H}_{2} \mathrm{O}$, strongly linked to the specific adsorption sites. The presence of four different adsorption site types was identified: two site types with high affinity for $\mathrm{CO}_{2}$, one for $\mathrm{H}_{2} \mathrm{O}$ and one on which $\mathrm{CO}_{2}$ and $\mathrm{H}_{2} \mathrm{O}$ can competitively adsorb. The $\mathrm{CO}_{2}$ adsorption sites can be easily regenerated in presence of $\mathrm{N}_{2}$, and the cycling is favored at high temperatures. In the most recent study of the same group (2018), the adsorption processes were studied by infrared spectroscopy, showing once again the presence of the four types of adsorption sites. The presence of water molecules enables the decomposition of the strong bonds with carbonate sites, ameliorating the cycling behavior. The comparison between LDHs and zeolites has been recently performed by Megías-Sayago et al. (2019) and the importance of the surface area was evidenced. While zeolites exhibited surface areas 
around $360 \mathrm{~m}^{2} \cdot \mathrm{g}^{-1}$ and adsorb $\mathrm{CO}_{2}$ up to $1.142 \mathrm{mmol} \cdot \mathrm{g}^{-1}, \mathrm{MgAl}$ and $\mathrm{CaAl}$ LDHs presented lower specific surface areas $\left(50\right.$ and $\left.21 \mathrm{~m}^{2} \cdot \mathrm{g}^{-1}\right)$ and adsorb carbon dioxide up to 0.68 and 0.10 mmol.g ${ }^{-1}$, respectively.

Table 3 and Fig7. display the $\mathrm{CO}_{2}$ adsorption capacities of various LDHs reported in the literature. Non-modified materials exhibit values between 0.5 and $1 \mathrm{mmol} . \mathrm{g}^{-1}$, while modified LDHs present much higher values, up to $6.1 \mathrm{mmol} . \mathrm{g}^{-1}$.

As demonstrated by various studies, LDHs are interesting alternatives to zeolites and activated carbons for $\mathrm{CO}_{2}$ adsorption and storage. Adsorption capacities between 0.5 and 6 mmol.g ${ }^{-1}$ could be measured depending on the structural modifications, the pre-treatments performed prior the adsorption, and the configuration of the adsorption experiments (operating temperature and pressure, gas composition, time of adsorption). Older papers stated on the optimal synthesis conditions and co-precipitation performed at highsupersaturation seems to be the most adapted method. More recent researches focus on sorption-enhanced reaction processes, due to the needs of minimize the release of $\mathrm{CO}_{2}$ while producing hydrogen from methane. Regarding the synthesis process, co-precipitation allows to obtain large and crystalline particles, increasing the amount of basic sites that are required to reach large amounts of $\mathrm{CO}_{2}$ adsorbed. The calcination of such materials leads to the formation of mixed oxides with higher surface areas, and consequently an increased number of basic sites. One of the most important parameter to take into account in this application is the specific surface area that is strongly related to the $\mathrm{CO}_{2}$ adsorption capacity. Moreover, Table 2 evidences slightly higher adsorption capacities for the materials synthesized by coprecipitation at high supersaturation conditions than for those prepared at low supersaturation conditions, except in the samples modified with TEPA (up to $6 \mathrm{mmol.g}{ }^{-1}$ ), as shown by 
Thouchprasitchaia et al. (2018). However, the commercial hydrotalcite tested by Wu et al. (2013) exhibits similar adsorption capacities than the modified LDHs.

\subsubsection{NOx and SOx adsorption}

Among the wide family of atmospheric pollutants, nitrogen and sulfur-based molecules are emitted from power plants, petroleum refinery, and vehicle engines (Yang et al. 2014). Nitrogen oxides (NOx) and Sulfur oxides ( $\mathrm{SOx}$, a mixture of $\mathrm{SO}_{2}$ and $\mathrm{SO}_{3}$ ) are released into the atmosphere with exhausted gases, causing environmental and climatic concerns such as acid rains, photochemical smog and human diseases (asthma for example) (Corma et al. 1997; Yu et al. 2006; Yang et al. 2014; Wang et al. 2018). The control of these emissions is becoming mandatory due to the increased awareness towards the climate change. Moreover, several laws and strict regulations have been put into place in the last decade, and encourage researches on more efficient ways to reduce them. Several depollution processes have been developed with good results, such as the direct decomposition (Yokomichi et al. 1996; Imanaka and Masui 2012; Gunugunuri et al. 2018; Gunugunuri and Roberts 2019), adsorption (Mahzoul et al. 1999; Sedlmair et al. 2003; Atribak et al. 2009), Selective Catalytic Reduction (SCR) (Lukyanov et al. 1995; Forzatti et al. 2010; Gao et al. 2018; Gramigni et al. 2019; Wu et al. 2019b; Li et al. 2019b), and NOx Storage and Reduction (NSR) (Castoldi et al. 2006; Breen et al. 2008; Sakano and Kawamura 2018; Umeno et al. 2019). LDHs are interesting due to their efficiency in a wide range of application, as catalysts and adsorbents. In recent years, hydrotalcite-like compounds have exhibited good NOx and SOx adsorption capacities. This chapter is dedicated to the adsorption and removal of these atmospheric pollutants by LDHs and related mixed oxides; the synthesis conditions of each LDH are reported in the Table 4 with the associated structural modifications. 
The most important part of the emitted NOx comes from the Fluid Catalytic Cracking (FCC) method employed by refinery processes to convert heavy distillates into lighter ones, such as gasoline and diesel. In this process, the catalyst gets progressively covered with coke and needs to be reactivated by burning and oxidizing the coke in a regenerator unit, NOx is here produced (Chaparala et al. 2015). The catalysts are reactivated by reduction at $750^{\circ} \mathrm{C}$, so most of the studies are focused on experiments under these conditions. The storage and catalytic reduction of NOx compounds on the surface of LDH catalysts occurs firstly on the catalytic sites to form nitrites and nitrates, as shown in Fig8, and according to the following reactions (Guo et al. 2018):

$$
\begin{aligned}
& \mathrm{NO}+\mathrm{Co}^{3+}-\mathrm{O}^{2-} \rightarrow \mathrm{Co}^{2+}-\left(\mathrm{ONO}^{-}\right) \text {formation of nitrite } \\
& \mathrm{NO}_{2}+\mathrm{Co}^{3+}-\mathrm{O}^{2-} \rightarrow \mathrm{Co}^{2+}-\left(\mathrm{ONO}_{2}^{-}\right) \text {formation of nitrate }
\end{aligned}
$$

Nitrites are unstable on the active sites and are then oxidized to nitrate in the presence of $\mathrm{O}_{2}$ or decomposed via the following reactions:

$$
\begin{aligned}
& 2 \mathrm{NO}_{2}^{-}+\mathrm{O}_{2} \rightarrow 2 \mathrm{NO}_{3}^{-} \text {by direct oxidation } \\
& \mathrm{Co}^{2+}-\left(\mathrm{ONO}^{-}\right) \rightarrow \mathrm{Co}^{3+}-\mathrm{O}^{2-}+\mathrm{NO} \text { by decomposition } \\
& 2 \mathrm{Co}^{2+}-\left(\mathrm{ONO}^{-}\right) \rightarrow 2 \mathrm{Co}^{3+}-\mathrm{O}^{2-}+\mathrm{N}_{2}+\mathrm{O}_{2} \text { by decomposition }
\end{aligned}
$$

The stored NOx is finally converted to $\mathrm{N}_{2}$ and $\mathrm{H}_{2} \mathrm{O}$ by reacting with $\mathrm{H}_{2}$ at $350^{\circ} \mathrm{C}$ :

$$
\begin{aligned}
& 2 \mathrm{NO}^{3-}+5 \mathrm{H}_{2} \rightarrow \mathrm{N}_{2}+\mathrm{O}^{2-}+5 \mathrm{H}_{2} \mathrm{O} \\
& 2 \mathrm{NO}^{2-}+3 \mathrm{H}_{2} \rightarrow \mathrm{N}_{2}+\mathrm{O}^{2-}+3 \mathrm{H}_{2} \mathrm{O}
\end{aligned}
$$

The first catalytic removal of NOx using copper-containing LDHs-derived mixed oxides has been reported in the late 90s by Corma et al. (1994). The possibility to incorporate the catalyst in the FCC units was explored, because NOx can be decomposed by the catalyst reduced under a reductive atmosphere at $550^{\circ} \mathrm{C}$, conditions close to those present in the regenerator unit of a FCC plant. The simultaneous removal of NOx and SOx in conditions close to those of the regenerator unit was investigated: Cu-mixed oxides derived from 
hydrotalcite showed to be able to remove both $\mathrm{SO}_{2}$ (via an oxidation or reduction reaction) and NO (via reduction and/or decomposition) at the same time in the presence of small amounts of $\mathrm{O}_{2}$ (between 0 and 1.5\%). Doping the catalysts with transition metals, such as cobalt, is of great interest on the storage capacity of NOx in hydrotalcites; Palomares et al. (1999) studied the catalytic activity of CoMgAl mixed oxides derived from hydrotalcites. Besides increasing the surface area by addition of cobalt, the authors concluded that in presence of $\mathrm{O}_{2}$ (up to $1 \%$ ) the catalyst is able to efficiently remove the atmospheric pollutants. In presence of oxygen in the feed and at $750^{\circ} \mathrm{C}$, cobalt-containing materials showed to be more selective towards NO reduction than Cu-based compounds. Almost $100 \%$ of NO conversion was reached in less than 50s and remained stable during time. Yu et al. (2006) prepared a range of $\mathrm{Co}_{x} \mathrm{Mg}_{3-x} / \mathrm{Al}$ hydrotalcite-like compounds, where $x$ varied from 0 (pure $\mathrm{MgAl}$ hydrotalcite) to 3 (pure CoAl hydrotalcite). Despite the decrease of the specific surface area while increasing the cobalt content, the results showed that higher storage capacities of NOx were reached at low temperatures with mixed oxides of intermediate Co concentrations $\left(0.22 \mathrm{mmol} . \mathrm{g}^{-1}\right.$ at $100^{\circ} \mathrm{C}$ for $\left.x=0.5\right)$. The pure phases exhibited the lowest storage capacities, around $0.14 \mathrm{mmol} . \mathrm{g}^{-1}$ for $\mathrm{MgAl}$ and $\mathrm{CoAl}$ hydrotalcites. These results are explained by the increase in the pore size, from $11.6 \mathrm{~nm}$ in the pure MgAl mixed oxides to $24.8 \mathrm{~nm}$ for the samples with the highest cobalt concentration. Similar experiments were performed the next year by the same team ( $\mathrm{Yu}$ et al. 2007) with two catalysts: $\mathrm{Ca}_{2} \mathrm{CoAl}$-oxide and $\mathrm{Ca}_{2} \mathrm{CoLa}_{0.1} \mathrm{Al}_{0.9}$-oxide, derived from their $\mathrm{LDH}$ precursors. NOx storage capacities up to 0.65 mmol.g ${ }^{-1}$ at $250^{\circ} \mathrm{C}$ were measured. Noble metals such as platinum, palladium and ruthenium have also been intensively studied towards the storage of NOx due to their high catalytic redox properties. Cheng et al. (2004) worked on Pt/MgAl oxides: MgAl oxides supports with different molar ratios were obtained by calcination of hydrotalcites, while platinum cations were incorporated by incipient wetness impregnation. The authors concluded that by 
579

580

581

582

583

increasing the $\mathrm{Mg} / \mathrm{Al}$ molar ratio in the initial hydrotalcites, the stored amount of NOx at $350^{\circ} \mathrm{C}$ was enhanced. Moreover, the addition of platinum as active phase greatly improved the NOx storage capacity (from 0.06 to $0.50 \mathrm{mmol} . \mathrm{g}^{-1}$ ). NOx are stored as nitrates that are more stable over $\mathrm{Pt} / \mathrm{Mg}$ oxides than over $\mathrm{Pt} / \mathrm{MgAl}$ oxides. A similar approach has been performed by Silletti et al. (2006) with $\mathrm{Pd} / \mathrm{MgAl}$ oxides. Additional adsorption sites were created, bringing to an increase of $70 \%$ in the adsorption capacity, when compared to the $\mathrm{MgAl}$ oxides (according to the reaction $\mathrm{PdO}_{(\mathrm{s})}+\mathrm{NO}_{2} \rightarrow \mathrm{Pd}\left(\mathrm{NO}_{3}\right)_{(\mathrm{s})}$ ). Finally, $\mathrm{RuMgAl}$ oxides have been reported by Li et al. (2007) and exhibited good performances, with a maximum storage capacity of $0.22 \mathrm{mmol} . \mathrm{g}^{-1}$ at $350^{\circ} \mathrm{C}$.

The most recent researches focus on low temperature storage and release of NOx between 150 and $300^{\circ} \mathrm{C}$, as reported by Cui et al. (2019) with manganese-doped mixed oxides derived from hydrotalcite precursors. The incorporation of manganese provokes changes in the crystal phases with formation of $\mathrm{Mn}_{3} \mathrm{O}_{4}$ and $\mathrm{MgMn}_{2} \mathrm{O}_{4}$ spinel besides brucite. These changes result in the increase of the surface area (from 108 to $139 \mathrm{~m}^{2} \cdot \mathrm{g}^{-1}$ ) and of the pore size (from 14 to 23 $\mathrm{nm}$ ), while the presence of manganese favors the oxidation of NO during adsorption. The largest adsorption capacity of $0.426 \mathrm{mmol} . \mathrm{g}^{-1}$ at $300^{\circ} \mathrm{C}$ was obtained in the presence of 15 $\mathrm{wt} \%$ of Mn, as reported in Fig9. The efficiency of LDHs containing various metallic elements towards the adsorption of NOx pollutants has also been reported by Li et al. (2019b) on a novel NiMnTi mixed oxide, showing high surface area and strong reducibility, resulting in strong surface acidity. Moreover, manganese, nickel and titanium give interesting redox properties to LDHs and gained interest in the last years (Wang et al. 2018; Wu et al. 2019b; Li et al. 2019b). The recent study performed by Kameda et al. (2019) presents another approach on the adsorption of NOx. The employed catalysts were fresh MgAl hydrotalcites that could be simply recycled by anion desorption in a solution of $\mathrm{Na}_{2} \mathrm{CO}_{3}$. Low $\mathrm{NO}$ removal rate was 
603

604

605

606

607

608

609

610

611

612

613

614

615

616

617

618

619

620

621

622

623

624

625

626

627

observed, but the removal of $\mathrm{NO}_{2}$ was possible, and stable at around $50 \%$ removal degree, during 3 cycles.

Concerning SOx removal for industrial applications, several patents are related to the use of hydrotalcites in FCC units (Pinnavaia et al. 1991, 1992; Vierheilig 2003). These compounds are emitted during the oxidative regeneration process of the catalysts at $700-800^{\circ} \mathrm{C}$. The general FCC process applied to the SOx removal is schematized in Fig10. Regarding the process conditions, several requirements are needed to trap SOx (Mathieu et al. 2013): (1) a high thermal stability of the adsorbent under FCC conditions, (2) the ability to oxidize $\mathrm{SO}_{2}$ to $\mathrm{SO}_{3}$, (3) the possibility to regenerate the adsorbent under a reductive flow of $\mathrm{H}_{2}$ to release sulfur as $\mathrm{H}_{2} \mathrm{~S}$, (4) the possibility to strongly chemisorb SOx in the regenerator unit, and (5) the absence of negative impact of the adsorbent on the conversion and selectivity of FCC products. LDHs and hydrotalcites can answer to these requirements: they have the ability to form mixed oxides of the desired elements, stable at high temperatures, and are able to be regenerated in water. The catalytic activity of such compounds strongly depends on the surface area (related to the number of active sites) and on the type of metallic cation employed (for their ability to react with SOx compounds) (Cantú et al. 2005; Valente and Quintana-Solorzano 2011; Mathieu et al. 2013). The first experiments, focused on $\mathrm{MgO}$, $\mathrm{Al}_{2} \mathrm{O}_{3}$ and $\mathrm{MgAl}$ spinels derived from pure $\mathrm{MgAl}$ hydrotalcites, showed very low performances; $\mathrm{MgO}$ forms stable $\mathrm{MgSO}_{4}$ compounds and $\mathrm{Al}_{2} \mathrm{O}_{3}$ forms $\mathrm{Al}_{2}\left(\mathrm{SO}_{4}\right)_{3}$ that is very unstable at these temperatures, leading to the release of sulfate species in the regenerator (Yoo et al. 1992). Three basic reactions are involved in the removal of SOx in the FCC regenerators (Yoo et al. 1992):

(1) $\mathrm{SO}_{2}+\mathrm{O}_{2} \rightarrow \mathrm{SO}_{3}$

(2) $\mathrm{SO}_{3}+\mathrm{MgO} \rightarrow \mathrm{MgSO}_{4}$

(3) $\mathrm{MgSO}_{4}+4 \mathrm{H}_{2} \rightarrow \mathrm{MgO}+\mathrm{H}_{2} \mathrm{~S}+3 \mathrm{H}_{2} \mathrm{O}$ 
Based on these equations, several oxides derived from hydrotalcites and LDHs have been tested in the last decade. The most studied samples were prepared by addition of transition metals similar to those used in the NOx removal processes. Cantú et al. (2005) reported for example on mixed oxides derived from $\mathrm{MgAlFeCe}$ hydrotalcites. Despite the lower surface area and low $\mathrm{SO}_{2}$ adsorption capacity, the oxides containing iron and cerium presented an interesting resistance to deactivation. The addition of cerium increased the adsorption rates and reduced the saturation times, while a limited amount of iron improved the catalytic regeneration of SOx adsorbents. A similar study was then performed by Valente and Quintana-Solorzano (2011) in partial and full combustion conditions (used for regeneration). The performances of mixed oxides derived from $\mathrm{MgAlFeCe}$ hydrotalcites were compared to those of a commercial catalyst. Hydrotalcites showed a lower deactivation rate and the necessity to use $33 \%$ less material than the commercial catalyst. However, only very few recent papers report on the adsorption and removal of SOx by LDHs-based materials. The most recent researches focus on catalysts capable of simultaneously adsorb SOx and NOx (Kameda et al. 2011, 2019a, 2020).

NOx and SOx are dangerous compounds formed during the regeneration process of the catalysts employed in the FCC units. Due to their toxicity, their removal has been widely studied. Hydrotalcites and mixed oxides derived from LDHs, in particular those containing transition metals (copper or cerium) or noble metals (platinum, palladium or ruthenium) have been considered for this application. High specific surface area, large pore sizes and improved catalytic properties have been obtained by the addition of metallic cations, leading to interesting results in NOx and SOx adsorption in regeneration conditions (around $750^{\circ} \mathrm{C}$ under a reducing atmosphere). Co-precipitation was the most widely used synthesis method for LDHs, allowing to obtain high specific surface areas, pore sizes and a high number of 
active sites. Higher adsorption capacities were reached with co-precipitated LDHs (0.10-0.65 mmol.g ${ }^{-1}$ ), compared to commercial samples (up to $0.06 \mathrm{mmol} . \mathrm{g}^{-1}$ ), as shown by the Table 3 . The specific surface areas remain in the same range of values (between 100 and $250 \mathrm{~m}^{2} \cdot \mathrm{g}^{-1}$ ) thanks to the modifications performed on the commercial LDHs, which evidences that the specific surface area is not the only parameter to be taken into consideration for increasing the performances in this application. Some additional studies have been performed on the simultaneous adsorption of NOx and SOx in order to obtain a polyvalent compound stable under the conditions of the FCC regenerator units (Kameda et al. 2011, 2019a, 2020).

\subsubsection{VOCs total decomposition}

Volatile Organic Compounds (VOCs) give origin to an important class of organic pollutants, such as toluene, ethanol, methanol, acetone and ethylene (Bahranowski et al. 1999; Carpentier et al. 2002; Gennequin et al. 2010a; Mrad et al. 2015; Kamal et al. 2016). They are emitted from various industrial processes and transport vehicles and represent a serious environmental problem. VOCs are the major contributors to air pollution due to their direct toxic and carcinogenic properties, or indirect contribution to ozone formation. The decomposition of VOCs is thereby crucial for an environmental point of view. VOCs removal requires technologies working under hard conditions (temperatures up to $1100^{\circ} \mathrm{C}$ and presence of toxic products). The possibility to eliminate VOCs at temperatures lower than those reached during classical combustion is of great interest. Catalytic total combustion of VOCs is then one of the most effective and economically attractive treatment explored in the last decades (Bahranowski et al. 1999; Mikulová et al. 2007; Dula et al. 2007; Tanasoi et al. 2009; Palacio et al. 2010; Kamal et al. 2016). Most catalysts used for the total decomposition of VOCs contain noble metals, such as palladium and gold. Mixed oxides based on transition metals have been also successfully tested with similar activity, as cheaper alternative. The 
catalysts must present a high thermal stability and a large number of active sites. Coprecipitation is once again the most adapted method to obtain the desired properties. It permits to easily substitute cations in the structure and to promote the formation of large platelets with a high number of active sites. The synthesis conditions of all the samples cited in this part have been listed in Table 5.

Similarly to $\mathrm{CO}_{2}$ adsorption, the total decomposition of VOCs by hydrotalcites and LDHs has been studied on various catalysts presenting different substitutions, and in different analytical conditions. The tests were mainly focused on the total decomposition of toluene or ethanol. The first experiments focused on the elimination of VOCs by mixed oxides derived from LDHs have been performed in the late 90 s, even if the reaction was already known since many decades. Moderated temperatures, around $200^{\circ} \mathrm{C}$, are required for this catalytic reaction. The catalysts are mixed oxides and amorphous phases obtained by calcination of LDHs at high temperature. Bahranowski et al. (1999) reported on the impact of $\mathrm{Cu}$ (II) and $\mathrm{Cr}(\mathrm{III})$ cations in mixed oxides derived from parent LDHs on the total oxidation of toluene and ethanol performed at various temperature. The authors observed that the purity and crystallinity of the materials depends on the initial $\mathrm{Cu}: \mathrm{Cr}$ molar ratio, and that the catalyst derived from the $\mathrm{CuCr}$ hydrotalcite, with an initial $\mathrm{Cu}: \mathrm{Cr}$ molar ratio of 2 , gave the best catalytic performances in both toluene and ethanol oxidations. A similar study, focused on the crystallinity of the LDH precursors, was performed few years later by Mikulova et al. (2007) on calcined NiAl LDHs. The analyses showed slightly lower catalytic activities than for $\mathrm{CuCr}$ hydrotalcites-derived oxides synthesized by Bahranowski et al. (1999) towards toluene oxidation. In ethanol oxidation, the formation of reaction intermediates, such as acetaldehyde, could be avoided by increasing the reaction temperature. Cobalt-containing hydrotalcite precursors with different compositions were tested by Gennequin et al. (2009, 2010b). They 
showed interesting activities in toluene oxidation, especially the sample containing the highest amount of cobalt, that presented the highest specific surface area, well dispersed oxides and lower presence of cobalt aluminate species. Fig11. shows the impact of the calcination temperature of Co-containing hydrotalcites on the toluene conversion. The same research group also performed studies focused on the memory effect of hydrotalcite (Gennequin et al. 2010a), their ability to regenerate their structure by simple wetting or impregnation. In this case, cobalt impregnation led to the partial regeneration of the LDH structure and improved the toluene oxidation activity.

Palacio et al. (2010) studied the impact of different trimetallic hydrotalcites $(\mathrm{ZnCuAl}$ and $\mathrm{MnCuAl}$ ), after calcination at $450^{\circ} \mathrm{C}$, over the oxidation of toluene. The $\mathrm{MnCuAl}$ catalysts showed to be the most efficient (Mrad et al. 2015). Dula et al. (2007) performed a similar study on MgAlMn-oxide (obtained from calcination of the parent LDH). The catalyst was more active than $\mathrm{MnO}_{4}$-impregnated $\mathrm{MgAl} \mathrm{LDH}$ for the combustion of toluene under air. This behavior can be explained by the enhanced presence of redox sites on the surface of the as-generated mixed oxide particles. Methane is a bit more difficult to oxidize due to its high inertness: its complete oxidation occurs at much higher temperature than toluene and ethanol, as studied by Tanasoi et al. (2009), with $50 \%$ of methane decomposition at $480-490^{\circ} \mathrm{C}$ over a calcined $\mathrm{Cu}$-containing MgAl-LDH catalyst. This work shows that the catalytic activity is dependent of the reducible amount of copper in the catalyst. Aguilera et al. (2011) performed a more complete study on the total oxidation of 3 different VOCs: butanol, ethanol and toluene by copper-manganese and cobalt-manganese catalysts derived from the parent LDHs. The catalytic activity depended on the VOC type, and the activity scale was the following for both catalyst: butanol < ethanol < toluene. Some other studies (Chmielarz et al. (2012)) focused on mono-carbon VOCs (methane, methanol, and formic acid). The calcination temperature had a direct impact on the complete oxidation: the presence of cobalt phases, 
obtained at high calcination temperatures (up to $800^{\circ} \mathrm{C}$ ), induced higher catalytic activities in conversions of methanol and formic acid.

Other modifications, such as the type of interlayer anion or the use of a support, can be introduced in the catalyst conception. Carpentier et al. (2002) demonstrated that the substitution of carbonate anions by palladium complexes in the interlayer space of $\mathrm{Mg} / \mathrm{Al}$ hydrotalcites improves the catalytic activity. Kovanda and Jirátová (2011a, b) supported several mixed oxides, derived from hydrotalcites, on $\mathrm{Al}_{2} \mathrm{O}_{3} / \mathrm{Al}$ or calcined alumina, and resulted in interesting catalytic activities with the production of side products such as acetaldehyde. Spinel phases identified in the calcined samples are also linked to the high conversion values observed.

Similar to $\mathrm{CO}_{2}$ adsorption, the total elimination of VOCs remains a very important environmental issue to be solved. Most of the LDHs used in this field are synthesized by coprecipitation method that makes possible the structural substitution of metallic cations, such as chromium or copper, in order to increase the catalytic activity. Differently than for the samples used in NOx and SOx adsorption, the materials prepared for VOCs elimination, and that contains metal cations in the structure, show similar specific surface area values (between 10 and $250 \mathrm{~m}^{2} \cdot \mathrm{g}^{-1}$ ) when obtained at low or high supersaturation conditions (Table 5). The main differences in the samples comes essentially from the inserted metallic cation and the thermal treatment (temperature and duration). According to the literature, the total elimination of VOCs by LDH-based materials is very promising.

\subsection{Adsorption of aqueous pollutants}

Nowadays the pollution of water is mainly deriving from several industrial effluents (papermaking, textiles and dyeing for example) and agricultural activities (Chuang et al. 
2008; Tzompantzi et al. 2011; Ali 2012). Some of the pollutants released in nature can move into soils and plants. Their high mobility provokes a global concern due to their significant impact on the human health, biotoxicity and carcinogenic effects (Lv et al. 2006; Chuang et al. 2008). As water resource is a fundamental resource on earth and remains rare in some regions, the need to find cheap and efficient depollution processes has increased worldwide. The wide family of aqueous pollutants includes inorganic pollutants (toxic heavy metals such as $\mathrm{As}, \mathrm{Pb}, \mathrm{Cd}, \mathrm{Ni}, \mathrm{Zn}$ and $\mathrm{Cr}$ for example (Lehmann et al. 1999; Yang et al. 2005; El-Sayed et al. 2016; Wan et al. 2017)), organic pollutants (mainly dyes from paper and textile industries (Tzompantzi et al. 2011; Ahmed and Gasser 2012; de Sá et al. 2013; Shan et al. 2014), but also drugs and pharmaceuticals (Chuang et al. 2008; Zhao et al. 2015; Yu et al. 2017)). Many approaches have been proposed for water treatment, including coagulation (Zou et al. 2016a, b), precipitation (Barrera-Díaz et al. 2012; Cheng et al. 2015), sedimentation (Rubí et al. 2009; Guo et al. 2009), sorption (Karickhoff 1984; Fosso-Kankeu et al. 2010; Alila et al. 2011), and ion exchange (Leinonen et al. 1994; Mazur et al. 2016). Regarding the literature, sorption is the most versatile process for removing pollutants at relatively low concentrations, and it is environmentally friendly. This process includes the use of lamellar materials such as clay minerals (Milutinović-Nikolić et al. 2014, p. 99; Wang et al. 2015; Yang et al. 2015) and LDHs (Yang et al. 2005; Chuang et al. 2008; Ahmed and Gasser 2012; Zou et al. 2017), but also activated carbons (Beita-Sandí et al. 2016; Bedin et al. 2016), graphene (Li et al. 2012; Song et al. 2015; Sun et al. 2017), and metal oxides (Tzompantzi et al. 2011; Cheng et al. 2015; Zou et al. 2017). The main obstacle using these materials is their relatively low adsorption capacity, so the majority of the studies is focused on increasing their efficiency. This part of the review discusses about the last advances in the use of LDHs and derived mixed oxides in the adsorption and removal or aqueous pollutants in the last decades. The synthesis parameters of the materials described in this part are listed in the Table 6. 
Inorganic pollutants are mainly constituted of heavy metals such as arsenic, lead, cadmium, nickel, zinc and chromium. Their toxicity has been well documented, and their removal gained large focus in the last decades (Barrera-Díaz et al. 2012). Thanks to their accessible and expansible interlayer space, LDHs are interesting adsorbents and ion exchangers of these pollutants. Their use has been firstly documented in the late ' 90 s and the performances often compared to those of other inorganic sorbents, such as activated carbons and metal oxides (Lehmann et al. 1999). Pure MgAl hydrotalcites generally exhibit interesting removal capacities, up to $50 \%$ of $\mathrm{Cr}(\mathrm{VI})$ and $100 \% \mathrm{Zn}(\mathrm{II})$ at $\mathrm{pH} 4$, and are able to act as anionexchangers (in the interlayer space) and proton-acceptors (presence of carbonate ions $\mathrm{CO}_{3}{ }^{2-}$ ). Moreover, an increase of the solution $\mathrm{pH}$ leads to a partial dissolution of the LDH structure and causes the precipitation of cationic metal species increasing the overall removal of inorganic pollutants. These materials are also efficient towards the removal of trace levels of pollutants, such as arsenic and selenium for example, as described by Yang et al. (2005) by using calcined and uncalcined MgAl hydrotalcites. The adsorption values of uncalcined samples are strongly influenced by the $\mathrm{pH}$ of the solution, while no influence of $\mathrm{pH}$ was measured on calcined samples (Fig12). In both cases, the desorption of $\mathrm{As}(\mathrm{V})$ and $\mathrm{Se}(\mathrm{IV})$ strongly depended on the anion species, with maximum amounts of 100ppm in presence of $\mathrm{HPO}_{4}{ }^{2-}$ and $1000 \mathrm{ppm}$ with $\mathrm{SO}_{4}{ }^{2-}$, and with desorption yields close to $100 \%$. Several parameters influence the removal capacity by LDHs, such as the $\mathrm{pH}$ of the solution, the initial pollutant concentration, and the adsorbent dosage ( $\mathrm{Lv}$ et al. 2006). Similar to other applications previously discussed, the addition of metallic cations in the structure of LDHs and derived mixed oxides increases the specific surface area and the pore volume of these materials, leading to better sorption capacities. El-Sayed et al. (2016) reported the efficiency of MgAlZn mixed oxides derived from calcined hydrotalcites and observed adsorption capacities up to 1.98 and $1.19 \mathrm{mmol}^{-1} \mathrm{~g}^{-1}$ for $\mathrm{Co}(\mathrm{II})$ and $\mathrm{Ni}(\mathrm{II})$, respectively. A more recent 
study showed the positive impact of incorporating LDHs onto a matrix of other nature. Once incorporated into biochar (Xue et al. 2016), MgFe LDHs can uptake nitrates with values up to $0.4 \mathrm{mmol} . \mathrm{g}^{-1}$, which are higher than those obtained on MgFe LDHs alone $\left(0.08 \mathrm{mmol} . \mathrm{g}^{-1}\right)$ or on activated carbons $\left(0.15 \mathrm{mmol} \cdot \mathrm{g}^{-1}\right)$. Chitosan has also been tested due to the possibility to adsorb large amounts of metal ions. Indeed, TiFe LDHs modified with chitosan can exhibit high removal capacities (close to 100\%) for cadmium and phosphate in mono- and multiplepollutant solutions (Mahmoud et al. 2017). The use of hierarchical $\mathrm{SiO}_{2} @ \mathrm{LDHs}$ on $\mathrm{SiO}_{2}$ spheres has been studied by Yang et al. (2017) to remove uranium (U(VI)) from aqueous solution. Thanks to the complexations and electrostatic interactions with the abundant oxygen-containing functional groups, a maximum sorption capacity of $1.27 \mathrm{mmol} . \mathrm{g}^{-1}$ was reported. Similar adsorption capacities have been reported by Zou et al. (2017) using CaMgAl LDHs and derived mixed oxides, with values depending on the calcination temperature of the LDH: from 0.55 (for uncalcined $\mathrm{LDH}$ ) up to $2.04 \mathrm{mmol.g}^{-1}$ (for calcined $\mathrm{LDH}$ at $500^{\circ} \mathrm{C}$ ). Another family of pollutants regroups the organic aqueous pollutants (pharmaceuticals and molecules with high molecular mass) that are released in nature by chemical industries, creating serious environmental issues due to their high toxicity, even at low concentrations (Chuang et al. 2008; Tzompantzi et al. 2011). The interest in finding new sorbent for removing such compounds from water increased in the last ten years, even if the toxicity and the possibility to adsorb these pollutants by natural materials is known since the ' 80 (Zepp and Schlotzhauer 1981; Karickhoff 1984). Sorption is one of the most common treatment to remove organic pollutants from nature; LDHs and derived mixed oxides are great candidates thanks to the high sorption capacity in the interlayer region, the large specific surface area and the presence of reactive surfaces (Pavan et al. 1999, 2000; Seki and Yurdakoç 2005; Chuang et al. 2008). Phenolic compounds are the most common organic water pollutants and their adsorption has been widely studied. Tzompantzi et al. (2011) reported on the fast 
828

829 LDHs. The photodegradation rate is maximized thanks to the electron transfer from $\mathrm{Zn}^{2+}$ to

$830 \mathrm{Al}^{3+}$. The removal of phenol molecules by photocatalysis has also been reported by Seftel et

831

832

833

834

835

836

837 al. (2015) using $\mathrm{TiO}_{2}$ deposited on various LDHs matrices presenting different cation compositions $\left(\mathrm{Zn}^{2+}, \mathrm{Cu}^{2+}, \mathrm{Al}^{3+}, \mathrm{Fe}^{3+}\right.$ and $\left.\mathrm{Ti}^{4+}\right)$. The specific surface area depended on the cations (from $5 \mathrm{~m}^{2} \cdot \mathrm{g}^{-1}$ with Cu-substituted $\mathrm{LDH}$ to $199 \mathrm{~m}^{2} \cdot \mathrm{g}^{-1}$ for Fe-substituted LDH), and almost $90 \%$ efficiency towards phenol adsorption by all the $\mathrm{TiO}_{2}$-modified LDHs was obtained after $5 \mathrm{~h}$ of UV and visible light irradiation.

Concerning dyes elimination from aqueous solutions, a number of technologies were recently developed, such as the adsorption by activated carbon (Özacar and Şengil 2002) or the nanofiltration (Koyuncu 2002; Lau and Ismail 2009). However, the formation of sludges in large quantities or the high operation cost make them not suitable for industrial and largescale applications (Ahmed and Gasser 2012). The low cost and regeneration properties of LDHs make the use of such materials interesting, as demonstrated by Ahmed and Gasser (2012) on the removal of Crystal Red, an anionic dye. Fig13 shows the adsorption of the dye; after only $15 \mathrm{~min}, 97 \%$ of the dye is removed when starting from a solution with a concentration of $100 \mathrm{mg} . \mathrm{L}^{-1}$. Moreover, LDH can be regenerated and cycled several times. Similar experiments were also performed by de Sá et al. (2013) with the Sunset Yellow FCF, a synthetic dye used to color food. The increase of the interlayer distance was observed, indicating that the adsorption takes place by simple ion exchange in this area. Magnetic materials can also be great sorbents towards organic dyes, as studied by Shan et al. (2014) by using magnetic $\mathrm{Fe}_{3} \mathrm{O}_{4} / \mathrm{MgAl}$ hydrotalcites to remove three different red dyes (reactive red, congo red, and acid red 1). The uptake equilibrium was reached after $30 \mathrm{~min}$ without significant impact on the solution $\mathrm{pH}$. The different results reported all along this review show that the morphology of the LDHs has a great impact on the specific surface area and plays a 
role on the adsorption capacity. A recent study performed by Li et al. (2016) focused on the adsorption of congo red by MgAl hydrotalcite. The specific surface area increased from 24.74 to $165.07 \mathrm{~m}^{2} \cdot \mathrm{g}^{-1}$ upon calcination of the parent hydrotalcite, due to the enhancement of the microporosity deriving from the dehydroxylation of the layers and the decomposition of carbonate anions. However, only a slight increase of the adsorption capacity (from 0.186 to $0.206 \mathrm{mmol} . \mathrm{g}^{-1}$ ) was observed. Indeed, the adsorption mechanism implies the anion exchange in the interlayer space and the sorption on the external surface, while the internal surface related to microporosity is not involved in the process due to accessibility problems.

The adsorption of aqueous pollutants, inorganic (toxic heavy metals) and organic (dyes and heavy molecules), by LDHs and derived mixed oxides has been discussed. Due to the increase of industrial and agricultural activities, these dangerous and harmful compounds can be found in high concentrations and need to be removed from aqueous media. Their sorption by lamellar materials, more specifically LDHs, is one of the most investigated solutions. As the adsorption of these pollutants takes place in the interlayer space and on the external surfaces, LDHs and derived mixed oxides with large external specific surface area are required. The coprecipitation method is the most employed because of its ability to form a wide range of LDHs with high crystallinity and reactive surfaces, mainly by substituting magnesium and/or aluminum by other metallic cations in the structure at different molar ratios. According to Table 6, similar specific surface areas were obtained with the samples synthesized by coprecipitation either at low or high supersaturation conditions (between 5 and $230 \mathrm{~m}^{2} \cdot \mathrm{g}^{-1}$ ). Other synthesis methods such as the ball milling (Mahmoud et al. 2017) or the ethanol-water mediated solvothermal method ( $\mathrm{Li}$ et al. 2016) are also interesting alternatives to obtain materials with high surface areas (around $150 \mathrm{~m}^{2} \cdot \mathrm{g}^{-1}$ ). Based on the existing literature, the adsorption of aqueous pollutants on LDHs and their derived materials reveals to be a promising alternative. 
2.2. Other applications

\subsubsection{Hydrogen production}

881

The need of alternative energies to replace fossil fuels is growing since the last decade.

882

883

884

885

886

887

888

889

890

891

892

893

894

895

896

897

898

899

900

901

902

Hydrogen is a clean energy vector that can be produced from several processes such as steam reforming, partial oxidation, or Sorption Enhanced Reaction Process (SERP) (Marquevich et al. 2001; He et al. 2009, 2010; Halabi et al. 2012a, b; Chanburanasiri et al. 2013; Cesar et al. 2016; Homsi et al. 2017). Hydrogen production is carried out in presence of $\mathrm{CO}_{2}$ adsorption processes (as reported in the section "2.1.1 $\mathrm{CO}_{2}$ adsorption - Capture and storage"). Sikander et al. (2017) reported in a review article the different hydrogen production processes carried out in the presence of hydrotalcite-base catalysts. The feedstock is generally constituted of light hydrocarbons such as ethanol, methanol or methane, even if biomass is a promising environment-friendly hydrogen source being highly available worldwide, relatively cheap and renewable (He et al. 2009, 2010; Contreras et al. 2014; Cesar et al. 2016; Zardin and PerezLopez 2017; García-Sancho et al. 2018; Sikander et al. 2018). The hydrogen production reactions are reported in the following equations (de Souza et al. 2012):

(1) $\mathrm{C}_{2} \mathrm{H}_{5} \mathrm{OH}+\mathrm{H}_{2} \mathrm{O} \rightarrow 2 \mathrm{CO}+4 \mathrm{H}_{2}$ in presence of ethanol in water,

(2) $\mathrm{C}_{2} \mathrm{H}_{5} \mathrm{OH} \rightarrow \mathrm{CH}_{3} \mathrm{CHO}+\mathrm{H}_{2}$

(3) $\mathrm{CH}_{3} \mathrm{CHO} \rightarrow \mathrm{CH}_{4}+\mathrm{CO}$ by decomposition of ethanol and the further decomposition of acetaldehyde,

(4) $\mathrm{CH}_{4}+\mathrm{H}_{2} \mathrm{O} \rightarrow \mathrm{CO}+3 \mathrm{H}_{2}$ in presence of methane in water,

(5) $\mathrm{CH}_{4}+\mathrm{CO}_{2} \rightarrow 2 \mathrm{CO}+2 \mathrm{H}_{2}$ in presence of methane in carbon dioxide.

The drawback in using hydrotalcite-derived catalysts for these processes is the high operating temperature needed (up to $900^{\circ} \mathrm{C}$ ) to calcine the layered materials prior to the catalytic reaction. Moreover, the formation of carbon monoxide can lead to the formation of 
carbonaceous materials (also named coke) that brings to the progressive deactivation of the active sites, as shown by de Souza et al. (2012) in the Boudouard reaction: $2 \mathrm{CO} \rightarrow \mathrm{CO}_{2}+$ $\mathrm{C}_{(\mathrm{s})}$. The synthesis conditions of the LDHs and related mixed oxides discussed in this part are summarized in Table 7.

The first experiments using LDHs to produce hydrogen were performed, in the last decade, by steam reforming. Marquevich et al. (2001) studied the feasibility with sunflower oil, as feedstock, and Ni/Al mixed oxides derived from calcined LDHs, as catalyst. More recently, steam reforming was studied in the presence of hydrocarbons such as ethanol, methane or ethylene glycol. For each source, the key-point for process development is to identify the most efficient catalysts and synthesize it by varying the synthesis conditions or the chemical composition. Contreras et al. (2014) reported in a review article the various catalysts tested for hydrogen production by steam reforming. Ni-containing catalysts show very good catalytic activity for the conversion of ethanol and ethylene glycol, as shown by He et al. (2009, 2010) and Cesar et al. (2016), respectively. In the first case, the catalytic activity of Co-Ni catalysts decreased by increasing the nickel content. In presence of ethylene glycol, Cesar et al. (2016) showed that Pt-containing catalysts are the most active and selective. Finally, a complete study on the steam reforming process, carried out with methane as feedstock, has been reported by Halabi et al. (2012a, b), using calcined $\mathrm{K}_{2} \mathrm{CO}_{3}$-promoted $\mathrm{Mg} / \mathrm{Al}$ hydrotalcite with in-situ $\mathrm{CO}_{2}$ capture. A similar study has been performed by Chanburanasiri et al. (2013) by comparing the impact of different commercial $\mathrm{K}_{2} \mathrm{CO}_{3}$ on the sorption efficiency and $\mathrm{H}_{2}$ production. The co-precipitation method revealed to be the most adapted for the easy substitution of the cations in the structure. In some syntheses, coprecipitation was performed in the presence of urea in order to improve the crystal size and the number of active sites. 
Methane decomposition is the second process largely studied for hydrogen production.

929

930

931

932

933

934

935

936

937

938

939

940

941

942

943

944

945

946

947 catalytic activity.

Methane is firstly adsorbed on the surface of the catalysts and then decomposed on the active sites. Graphite-like structure or coke can accumulate on the active sites and block them, leading to a progressive deactivation of the catalyst. The presence of transition metals $(\mathrm{Ni}$, Co) in the catalyst structure positively contributes to methane decomposition at low temperatures and with high yields. By varying the $\mathrm{Cu} / \mathrm{Al}$ molar ratios (maintaining fixed $\mathrm{Ni}$ content) of calcined $\mathrm{Ni} / \mathrm{Cu} / \mathrm{Al}$ hydrotalcites, Ashok et al. (2008) identified the ideal composition $(\mathrm{Ni} / \mathrm{Cu} / \mathrm{Al}=60 / 25 / 15)$ to obtain the highest hydrogen yield. The amount of $\mathrm{Ni}$ in $\mathrm{Ni} / \mathrm{Mg} / \mathrm{Al}$ hydrotalcites can also be modulated; García-Sancho et al. (2017) investigated the influence of the nickel content on hydrogen production. Fig14. shows the methane conversion and the hydrogen production in the presence of hydrotalcites of various nickel content during temperature-programmed tests. 55\% of methane conversion with $100 \%$ hydrogen selectivity was measured on a catalyst containing $46 \%$ at of nickel in the structure. The conversion was not improved by increasing the nickel content, due to the presence of inactive isolated $\mathrm{Ni}$ particles among the spinel phases. One year later, the same team (García-Sancho et al. 2018) compared the impact of adding nickel during the synthesis of hydrotalcites prior to the calcination and to form bulk Ni-mixed oxides, or after the calcination of the hydrotalcites (to produce Ni-supported mixed oxides). The two kind of catalysts show similar activities, and only slight differences in the reduction temperatures of the catalysts were observed. The impact of the calcination temperature was studied by Sikander et al. (2018) on $\mathrm{Mg} / \mathrm{Ni} / \mathrm{Al}$ hydrotalcites with different nickel content. The sample containing $40 \%$ at nickel showed the best performances after calcination at 500 and $750^{\circ} \mathrm{C}$. The presence of spinel-like structures on the catalyst surface favors the diffusion of the deposited carbon, enhancing the overall 
Hydrogen can be produced by various processes, such as steam reforming and methane

954 decomposition. Highly active and selective catalysts exist and are listed in Table 8. The possibility to tune the catalysts composition is fundamental to form mixed oxides with high catalytic activity. Most of the studies discussed in this section are focused on the coprecipitation method for the possibility of operating structural substitutions, particularly to add nickel cations in the LDH structure. Table 7 also shows the interest in using coprecipitated LDHs instead of commercial samples; the specific surface areas of the synthesized samples is higher than that of the commercial ones (between 69 and $156 \mathrm{~m}^{2} \cdot \mathrm{g}^{-1}$ instead of 15-104 in the commercial hydrotalcites). Urea is also introduced during preparation in order to obtain a high number of active sites and increase the size of the platelets. Moreover, the hydrogen production can be combined with $\mathrm{CO}_{2}$ adsorption with interesting results. Combining $\mathrm{CO}_{2}$ capture and $\mathrm{H}_{2}$ formation in the same process is promising for future industrial applications.

\subsubsection{5-Hydroxymethylfurfural formation}

Thanks to its natural abundance, biomass is a promising sustainable feedstock: carbohydrates are the largest natural carbon source constituting up to $75 \%$ of the annual biomass production, with promising applications in chemistry, food, paper, and pharmaceutical industries (Rosatella et al. 2011; Zakrzewska et al. 2011). Carbohydrates are rich in oxygen and can be easily reduced and dehydrated into a large spectrum of chemicals such as 5-Hydroxymethylfurfural (5-HMF) or levulinic acid. The US Department of Energy listed 5-HMF among the top 10 value-added chemicals; it is generally used as an intermediate to synthesize a wide range of chemicals nowadays derived from petroleum. Unfortunately, 5HMF is not extensively produced at industrial scale due to the high production cost (van Putten et al. 2013). Fructose and glucose conversion are well-documented reactions that occur 
at relatively low temperature (below $150^{\circ} \mathrm{C}$ ). These mild reaction conditions allow the use of clays, hybrids and other lamellar materials as catalysts. The dehydration of fructose leads to the formation of 5-Hydroxymethylfurfural (5-HMF), the main reaction product, and other byproducts, such as levulinic acid and formic acid, that are formed by degradation of 5-HMF, as explained in Fig15. The catalysts used in this reaction must present a high specific surface area in order to maximize the catalytic surface and react with the fructose dissolved in the solvent (generally water). These requirements can be fulfilled by LDHs synthesized by the sol-gel method or any other method implying a hydrothermal treatment, and that present high specific surface areas and an improved thermal stability. The synthesis parameters of all the cited samples are reported in Table 9.

The main drawback in using clays, hybrids and other lamellar materials in catalytic reactions is their thermal stability. In typical natural clays, dehydration occurs below $200^{\circ} \mathrm{C}$ with the removal of interlayer and surface water, while irreversible dehydroxylation with formation of oxides starts already around $350^{\circ} \mathrm{C}$, depending on the type of metallic cations in the starting material. Several catalytic reactions occur above $300^{\circ} \mathrm{C}$, thus the majority of the studies performed with LDHs is based on mixed oxide catalysts obtained by their calcination. However, few experiments have been performed on modified clay minerals such as montmorillonite; thanks to their expandable layers and swelling properties, these minerals can be easily modified by ion-exchange and pillaring in order to modify their structural properties. Lourvanij and Rorrer (1994) studied the partial dehydration of glucose to organic acids on iron-, chromium-, aluminum-, and non-pillared montmorillonite. Their large pore size (higher than $10 \AA$ ) allows the diffusion of glucose molecules (equal to $8.6 \AA$ ) in the interlayer space, as demonstrated by the Fig16. Depending on the reaction path, coke formation, leading to their progressive deactivation, has been observed. Further studies have been performed by Fang et 
al. (2014) with a commercial montmorillonite (K-10) to compare the impact of the reaction

1004

1005

1006

1007

1008

1009

1010

1011

1012

1013

1014

1015

1016

1017

1018

1019

1020

1021

1022

1023

1024

1025

1026 solvent: dimethyl sulfoxide (DMSO) and butyl-3-methylimidazole chloride ([BMIM]Cl) were used. The results are shown in Fig17. and point out the higher conversion of glucose in presence of higher concentrations of $[\mathrm{BMIM}] \mathrm{Cl}$ in DMSO. The efficient recycling of the solvent (up to six times) without significant loss of the catalytic activity was also observed.

Beside the well-known basicity of hydrotalcites, LDHs and related materials, only few studies on the dehydration of fructose in 5-Hydroxymethylfurfural have been performed on these materials. However, recent researches pointed out the promising application of these materials in the transformation of biomass-derived monomers (Chheda and Dumesic 2007; Li et al. 2011; Climent et al. 2014). Zeolites are widely employed for such applications, but mixed oxides represent a great alternative thanks to their easy synthesis by sol-gel method or by simple thermal treatment of LDHs and hydrotalcites.

In the case of glucose catalysis, three different reactions can be expected: dehydration, isomerization, and retro-aldol condensation. The first reaction generally allows to form HMF and levulinic acid in the presence of acid catalysts, while the other reactions are favored in the presence of basic materials to form fructose or lactic acid. The bifunctional acid-base properties of Al-Zr mixed oxides bring to different reaction products: HMF and levulinic acid are formed by dehydration on the acid sites, while lactic acid and fructose are obtained by isomerization and retro-aldol condensation in the basic sites.

As explained in this part, the catalytic formation of 5-HMF by dehydration of glucose with the use of hydrotalcites or LDHs is not much documented, but the potential use of their related mixed oxides shows interesting results that may be promising for future researches as zeolite substitutes and needs further investigations. Even if the specific surface areas of the LDHs reported in the Table 9 are similar to those of modified montmorillonites, the catalytic 
activity in this application is related to the surface acidity, limiting the potential use of LDHs.

Moreover, the sol-gel method or hydrothermal treatment can be easily performed to obtain LDHs adapted to this application.

\section{Conclusion}

LDHs, hydrotalcites and their related materials gained huge interest in the last decades thanks to their simple synthesis processes and numerous applications. Even if they are mainly synthesized by co-precipitation or hydrothermal methods, the possibility to combine different $\mathrm{M}(\mathrm{II})$ and $\mathrm{M}(\mathrm{III})$ cations and interlayer anions in their structure allows to tailor the chemical composition, as well as their structural properties (surface areas, pore sizes, number of active sites), making them potential catalysts in several industrial and environmental processes. Moreover, their memory effect permits to reuse them many times, which is interesting at industrial scales.

In this review, the impact of synthesis methods on the structural and textural properties of LDHs has been discussed in order to identify the most suitable synthesis process for a chosen environmental application. The adsorption of pollutants (atmospheric and aqueous) and hydrogen production are important environmental applications in which LDHs can find their place. The key parameter for implementing the use of LDHs and derived materials is the choice of the appropriate synthesis process. The adsorption of pollutants requires high amount of basic sites and strong thermal stability that can be obtained using the co-precipitation method to synthesize LDHs. On the other side, the formation of 5-HMF takes place on the acid sites that can be potentially obtained by sol-gel or hydrothermal synthesis. Finally, the intercalation, impregnation or addition of appropriate elements (metals) with uniform 
1051

1052 hydrotalcites (Fig18.).

1053

1054

1055

1056

1057

1058

1059

1060

1061

1062

1063

1064

1065

1066

1067

1068

1069

1070

1071

1072

1073

1074

1075

1076

1077

1078

1079

\section{Acknowledgements}

\section{Abbreviations}

\section{References}

dispersion is important for hydrogen production to increase the catalytic activity of

The authors acknowledge the French Ministry of High Education and Research for the Ph.D.-student fellowship allowed to Dylan Chaillot.

LDH, Layered Double Hydroxide; 5-HMF, 5-Hydroxymethylfurfural; VOCs, Volatile Organic Compounds; TEPA, TeraEthylenePentAmine; SERP, Sorption Enhanced Reaction Process; HPLC, High Performance Liquid Chromatography; NMR, Nuclear Magnetic resonance; DMSO, DiMethyl SulfOxide.

Abelló S, Mitchell S, Santiago M, et al (2010) Perturbing the properties of layered double hydroxides by continuous coprecipitation with short residence time. J Mater Chem 20:5878. https://doi.org/10.1039/c0jm00088d

Adachi-Pagano M, Forano C, Besse J-P (2003) Synthesis of Al-rich hydrotalcite-like compounds by using the urea hydrolysis reaction-control of size and morphology. J Mater Chem 13:19881993. https://doi.org/10.1039/B302747N

Aguilera DA, Perez A, Molina R, Moreno S (2011) Cu-Mn and Co-Mn catalysts synthesized from hydrotalcites and their use in the oxidation of VOCs. Appl Catal B Environ 104:144-150. https://doi.org/10.1016/j.apcatb.2011.02.019

Ahmed IM, Gasser MS (2012) Adsorption study of anionic reactive dye from aqueous solution to MgFe-CO3 layered double hydroxide (LDH). Appl Surf Sci 259:650-656. https://doi.org/10.1016/j.apsusc.2012.07.092

Albuquerque DWS, Costa ES, de Miranda JL, et al (2016) Evaluation of the Behavior of Hydrotalcite Like-Materials for $\mathrm{CO}_{2}$ Capture. Appl Mech Mater 830:3-10. https://doi.org/10.4028/www.scientific.net/AMM.830.3 
Ali I (2012) New Generation Adsorbents for Water Treatment. Chem Rev 112:5073-5091. https://doi.org/10.1021/cr300133d

Alila S, Aloulou F, Thielemans W, Boufi S (2011) Sorption potential of modified nanocrystals for the removal of aromatic organic pollutant from aqueous solution. Ind Crops Prod 33:350-357. https://doi.org/10.1016/j.indcrop.2010.11.010

Aramendía M (2002) Comparative Study of Mg/M(III) (M=Al, Ga, In) Layered Double Hydroxides Obtained by Coprecipitation and the Sol-Gel Method. J Solid State Chem 168:156-161. https://doi.org/10.1006/jssc.2002.9655

Ashok J, Subrahmanyam M, Venugopal A (2008) Hydrotalcite structure derived Ni-Cu-Al catalysts for the production of $\mathrm{H} 2$ by $\mathrm{CH} 4$ decomposition. Int J Hydrog Energy 33:2704-2713. https://doi.org/10.1016/j.ijhydene.2008.03.028

Atadashi IM, Aroua MK, Abdul Aziz AR, Sulaiman NMN (2013) The effects of catalysts in biodiesel production: A review. J Ind Eng Chem 19:14-26. https://doi.org/10.1016/j.jiec.2012.07.009

Atribak I, Azambre B, Bueno López A, García-García A (2009) Effect of NOx adsorption/desorption over ceria-zirconia catalysts on the catalytic combustion of model soot. Appl Catal B Environ 92:126-137. https://doi.org/10.1016/j.apcatb.2009.07.015

Bahranowski K, Bielanska E, Janik R, et al (1999) LDH-derived catalysts for complete oxidation of volatile organic compounds. Clay Miner 34:67-77

Balsamo N, Mendieta S, Oliva M, et al (2012) Synthesis and Characterization of Metal Mixed Oxides from Layered Double Hydroxides. Procedia Mater Sci 1:506-513. https://doi.org/10.1016/j.mspro.2012.06.068

Bankauskaite A, Baltakys K (2011) The hydrothermal synthesis of hydrotalcite by using different partially soluble and insoluble in water mangesium and aluminium components. Sci Sinter 43:261-275. https://doi.org/10.2298/SOS1103261B

Barrera-Díaz CE, Lugo-Lugo V, Bilyeu B (2012) A review of chemical, electrochemical and biological methods for aqueous $\mathrm{Cr}(\mathrm{VI})$ reduction. J Hazard Mater 223-224:1-12. https://doi.org/10.1016/j.jhazmat.2012.04.054

Bedin KC, Martins AC, Cazetta AL, et al (2016) KOH-activated carbon prepared from sucrose spherical carbon: Adsorption equilibrium, kinetic and thermodynamic studies for Methylene Blue removal. Chem Eng J 286:476-484. https://doi.org/10.1016/j.cej.2015.10.099

Beita-Sandí W, Ersan MS, Uzun H, Karanfil T (2016) Removal of N -nitrosodimethylamine precursors with powdered activated carbon adsorption. Water Res 88:711-718. https://doi.org/10.1016/j.watres.2015.10.062

Benito P, Herrero M, Barriga C, et al (2008) Microwave-Assisted Homogeneous Precipitation of Hydrotalcites by Urea Hydrolysis. Inorg Chem 47:5453-5463. https://doi.org/10.1021/ic7023023

Benito P, Labajos FM, Rives V (2006) Uniform Fast Growth of Hydrotalcite-like Compounds. Cryst Growth Des 6:1961-1966. https://doi.org/10.1021/cg0506222 
Berber MR, Hafez IH, Minagawa K, et al (2013) Uniform nanoparticles of hydrotalcite-like materials and their textural properties at optimized conditions of urea hydrothermal treatment. J Mol Struct 1033:104-112. https://doi.org/10.1016/j.molstruc.2012.08.028

Bhatta LKG, Subramanyam S, Chengala MD, et al (2015) Enhancement in $\mathrm{CO}_{2}$ Adsorption on Hydrotalcite-based Material by Novel Carbon Support Combined with $\mathrm{K}_{2} \mathrm{CO}_{3}$ Impregnation. Ind Eng Chem Res 54:10876-10884. https://doi.org/10.1021/acs.iecr.5b02020

Bian L, Wang W, Xia R, Li Z (2016) Ni-based catalyst derived from Ni/Al hydrotalcite-like compounds by the urea hydrolysis method for CO methanation. RSC Adv 6:677-686. https://doi.org/10.1039/C5RA19748A

Bish DL (1980) Anion-exchange in takovite : applications to other hydroxide minerals. Bull Minéralogie 103:170-175. https://doi.org/10.3406/bulmi.1980.7392

Bolognini M, Cavani F, Scagliarini D, et al (2003) Mg/Al mixed oxides prepared by coprecipitation and sol-gel routes: a comparison of their physico-chemical features and performances in $\mathrm{m}$ cresol methylation. Microporous Mesoporous Mater 66:77-89. https://doi.org/10.1016/j.micromeso.2003.09.010

Bontchev RP, Liu S, Krumhansl JL, et al (2003) Synthesis, Characterization, and Ion Exchange Properties of Hydrotalcite $\mathrm{Mg}_{6} \mathrm{Al}_{2}(\mathrm{OH})_{16}(\mathrm{~A})_{x}\left(\mathrm{~A}^{\prime}\right)_{2-x} \cdot 4 \mathrm{H}_{2} \mathrm{O}\left(\mathrm{A}, \mathrm{A}^{\prime}=\mathrm{Cl}^{-}, \mathrm{Br}^{-}, \mathrm{I}^{-}\right.$, and $\mathrm{NO}$ $3^{-}, 2 \geq x \geq 0$ ) Derivatives. Chem Mater 15:3669-3675. https://doi.org/10.1021/cm034231r

Breen JP, Burch R, Fontaine-Gautrelet C, et al (2008) Insight into the key aspects of the regeneration process in the NOx storage reduction (NSR) reaction probed using fast transient kinetics coupled with isotopically labelled $15 \mathrm{NO}$ over Pt and Rh-containing Ba/Al2O3 catalysts. Appl Catal B Environ 81:150-159. https://doi.org/10.1016/j.apcatb.2007.12.016

Budhysutanto WN, Kramer HJM, van Agterveld D, et al (2010) Pre-treatment of raw materials for the hydrothermal synthesis of hydrotalcite-like compounds. Chem Eng Res Des 88:1445-1449. https://doi.org/10.1016/j.cherd.2009.10.010

Cantú M, López-Salinas E, Valente JS, Montiel R (2005) SOx Removal by Calcined MgAlFe Hydrotalcite-like Materials: Effect of the Chemical Composition and the Cerium Incorporation Method. Environ Sci Technol 39:9715-9720. https://doi.org/10.1021/es051305m

Carpentier J, Lamonier JF, Siffert S, et al (2002) Characterisation of Mg/Al hydrotalcite with interlayer palladium complex for catalytic oxidation of toluene. Appl Catal Gen 234:91-101. https://doi.org/10.1016/S0926-860X(02)00201-6

Castoldi L, Matarrese R, Lietti L, Forzatti P (2006) Simultaneous removal of NOx and soot on Pt$\mathrm{Ba} / \mathrm{Al} 2 \mathrm{O3}$ NSR catalysts. Appl Catal B Environ 64:25-34. https://doi.org/10.1016/j.apcatb.2005.10.015

Cesar DV, Santori GF, Pompeo F, et al (2016) Hydrogen production from ethylene glycol reforming catalyzed by $\mathrm{Ni}$ and Ni-Pt hydrotalcite-derived catalysts. Int J Hydrog Energy 41:2200022008. https://doi.org/10.1016/j.ijhydene.2016.07.168

Chanburanasiri N, Ribeiro AM, Rodrigues AE, et al (2013) Simulation of Methane Steam Reforming Enhanced by in Situ $\mathrm{CO}_{2}$ Sorption Using $\mathrm{K}_{2} \mathrm{CO}_{3}$-Promoted Hydrotalcites for $\mathrm{H}_{2}$ Production. Energy Fuels 27:4457-4470. https://doi.org/10.1021/ef302043e 
Chaparala SV, Raj A, Chung SH (2015) Reaction Mechanism for the Formation of Nitrogen Oxides (NO x) During Coke Oxidation in Fluidized Catalytic Cracking Units. Combust Sci Technol 187:1683-1704. https://doi.org/10.1080/00102202.2015.1059328

Cheng H, Chen G, Wang S, et al (2004) NOx storage-reduction over Pt/Mg-Al-O catalysts with different $\mathrm{Mg} / \mathrm{Al}$ atomic ratios. Korean J Chem Eng 21:595-600. https://doi.org/10.1007/BF02705493

Cheng Q, Wang C, Doudrick K, Chan CK (2015) Hexavalent chromium removal using metal oxide photocatalysts. Appl Catal B Environ 176-177:740-748. https://doi.org/10.1016/j.apcatb.2015.04.047

Chheda JN, Dumesic JA (2007) An overview of dehydration, aldol-condensation and hydrogenation processes for production of liquid alkanes from biomass-derived carbohydrates. Catal Today 123:59-70. https://doi.org/10.1016/j.cattod.2006.12.006

Chmielarz L, Piwowarska Z, Rutkowska M, et al (2012) Total oxidation of selected mono-carbon VOCs over hydrotalcite originated metal oxide catalysts. Catal Commun 17:118-125. https://doi.org/10.1016/j.catcom.2011.10.030

Chuang YH, Tzou YM, Wang MK, et al (2008) Removal of 2-Chlorophenol from Aqueous Solution by $\mathrm{Mg} / \mathrm{Al}$ Layered Double Hydroxide (LDH) and Modified LDH. Ind Eng Chem Res 47:3813-3819. https://doi.org/10.1021/ie071508e

Climent M (2004) Increasing the basicity and catalytic activity of hydrotalcites by different synthesis procedures. J Catal 225:316-326. https://doi.org/10.1016/j.jcat.2004.04.027

Climent MJ, Corma A, Iborra S (2014) Conversion of biomass platform molecules into fuel additives and liquid hydrocarbon fuels. Green Chem 16:516. https://doi.org/10.1039/c3gc41492b

Climent MJ, Corma A, Iborra S, Velty A (2004) Activated hydrotalcites as catalysts for the synthesis of chalcones of pharmaceutical interest. J Catal 221:474-482. https://doi.org/10.1016/j.jcat.2003.09.012

Coenen K, Gallucci F, Cobden P, et al (2017a) Chemisorption of H2O and CO2 on Hydrotalcites for Sorption-enhanced Water-gas-Shift Processes. Energy Procedia 114:2228-2242. https://doi.org/10.1016/j.egypro.2017.03.1360

Coenen K, Gallucci F, Mezari B, et al (2018) An in-situ IR study on the adsorption of CO 2 and H 2 O on hydrotalcites. J CO2 Util 24:228-239. https://doi.org/10.1016/j.jcou.2018.01.008

Coenen K, Gallucci F, Pio G, et al (2017b) On the influence of steam on the CO2 chemisorption capacity of a hydrotalcite-based adsorbent for SEWGS applications. Chem Eng J 314:554-569. https://doi.org/10.1016/j.cej.2016.12.013

Colonna S, Bastianini M, Sisani M, Fina A (2018) CO2 adsorption and desorption properties of calcined layered double hydroxides: Effect of metal composition on the LDH structure. J Therm Anal Calorim 133:869-879. https://doi.org/10.1007/s10973-018-7152-8

Contreras JL, Salmones J, Colín-Luna JA, et al (2014) Catalysts for $\mathrm{H} 2$ production using the ethanol steam reforming (a review). Int J Hydrog Energy 39:18835-18853. https://doi.org/10.1016/j.ijhydene.2014.08.072 
Corma A, Fornés V, Rey F (1994) Hydrotalcites as Base Catalysts: Influence of the Chemical Composition and Synthesis Conditions on the Dehydrogenation of Isopropanol. J Catal 148:205-212

Corma A, Palomares AE, Rey F, Márquez F (1997) Simultaneous Catalytic Removal of SOxand NOxwith Hydrotalcite-Derived Mixed Oxides Containing Copper, and Their Possibilities to Be Used in FCC Units. J Catal 170:140-149. https://doi.org/10.1006/jcat.1997.1750

Costantino U, Marmottini F, Nocchetti M, Vivani R (1998) New Synthetic Routes to Hydrotalcite-Like Compounds - Characterisation and Properties of the Obtained Materials. Eur J Inorg Chem 1998:1439-1446. https://doi.org/10.1002/(SICI)1099-0682(199810)1998:10<1439::AIDEJIC1439>3.0.CO;2-1

Cui, Ma, Wang, et al (2019) High Performance of Mn-Doped MgAlOx Mixed Oxides for Low Temperature NOx Storage and Release. Catalysts 9:677. https://doi.org/10.3390/catal9080677

Dadwhal M, Kim TW, Sahimi M, Tsotsis TT (2008) Study of $\mathrm{CO}_{2}$ Diffusion and Adsorption on Calcined Layered Double Hydroxides: The Effect of Particle Size. Ind Eng Chem Res 47:6150-6157. https://doi.org/10.1021/ie701701d

Dantas TCM, Junior VJF, Santos APB dos, et al (2015) $\mathrm{CO}_{2}$ Adsorption on Modified Mg-Al-Layered Double Hydroxides. Adsorpt Sci Technol 33:165-173. https://doi.org/10.1260/02636174.33.2.165

de Sá FP, Cunha BN, Nunes LM (2013) Effect of pH on the adsorption of Sunset Yellow FCF food dye into a layered double hydroxide (CaAl-LDH-NO3). Chem Eng J 215-216:122-127. https://doi.org/10.1016/j.cej.2012.11.024

de Souza G, Ávila VC, Marcílio NR, Perez-Lopez OW (2012) Synthesis Gas Production by Steam Reforming of Ethanol over M-Ni-Al Hydrotalcite-type Catalysts; M=Mg, Zn, Mo, Co. Procedia Eng 42:1805-1815. https://doi.org/10.1016/j.proeng.2012.07.575

Dou Y, Zhou S, Oldani C, et al (2018) 5-Hydroxymethylfurfural production from dehydration of fructose catalyzed by Aquivion@silica solid acid. Fuel 214:45-54. https://doi.org/10.1016/j.fuel.2017.10.124

Dula R, Janik R, Machej T, et al (2007) Mn-containing catalytic materials for the total combustion of toluene: The role of Mn localisation in the structure of LDH precursor. Catal Today 119:327331. https://doi.org/10.1016/j.cattod.2006.08.060

El Rouby WMA, El-Dek SI, Goher ME, Noaemy SG (2018) Efficient water decontamination using layered double hydroxide beads nanocomposites. Environ Sci Pollut Res. https://doi.org/10.1007/s11356-018-3257-7

El-Sayed M, Eshaq Gh, EIMetwally AE (2016) Adsorption of heavy metals from aqueous solutions by Mg-Al-Zn mingled oxides adsorbent. Water Sci Technol 74:1644-1657. https://doi.org/10.2166/wst.2016.329

Fang Z, Liu B, Luo J, et al (2014) Efficient conversion of carbohydrates into 5-hydroxymethylfurfural catalyzed by the chromium-exchanged montmorillonite K-10 clay. Biomass Bioenergy 60:171-177. https://doi.org/10.1016/j.biombioe.2013.12.002 
Forzatti P, Nova I, Tronconi E (2010) New "Enhanced NH 3 -SCR" Reaction for NOx Emission Control. Ind Eng Chem Res 49:10386-10391. https://doi.org/10.1021/ie100600v

Fosso-Kankeu E, Mulaba-Bafubiandi AF, Mamba BB, et al (2010) A comprehensive study of physical and physiological parameters that affect bio-sorption of metal pollutants from aqueous solutions. Phys Chem Earth Parts ABC 35:672-678. https://doi.org/10.1016/j.pce.2010.07.008

Gao C, Shi J-W, Fan Z, et al (2018) "Fast SCR" reaction over Sm-modified MnOx-TiO2 for promoting reduction of NOx with NH3. Appl Catal Gen 564:102-112. https://doi.org/10.1016/j.apcata.2018.07.017

Gao Y, Zhang Z, Wu J, et al (2013) Comprehensive investigation of CO2 adsorption on Mg-Al-CO3 LDH-derived mixed metal oxides. J Mater Chem A 1:12782. https://doi.org/10.1039/c3ta13039h

García-Sancho C, Guil-López R, Pascual L, et al (2017) Optimization of nickel loading of mixed oxide catalyst ex -hydrotalcite for $\mathrm{H} 2$ production by methane decomposition. Appl Catal Gen 548:71-82. https://doi.org/10.1016/j.apcata.2017.07.038

García-Sancho C, Guil-López R, Sebastián-López A, et al (2018) Hydrogen production by methane decomposition: A comparative study of supported and bulk ex-hydrotalcite mixed oxide catalysts with $\mathrm{Ni}, \mathrm{Mg}$ and Al. Int J Hydrog Energy 43:9607-9621. https://doi.org/10.1016/j.ijhydene.2018.04.021

Gastuche MC, Brown G, Mortland MM (1967) Mixed Magnesium-Aluminium Hydroxides I. Preparation and Characterization of Compounds Formed in Dialysed Systems. Clay Miner 7:177-192

Gennequin C, Barakat T, Tidahy HL, et al (2010a) Use and observation of the hydrotalcite "memory effect" for VOC oxidation. Catal Today 157:191-197. https://doi.org/10.1016/j.cattod.2010.03.012

Gennequin C, Kouassi S, Tidahy L, et al (2010b) Co-Mg-Al oxides issued of hydrotalcite precursors for total oxidation of volatile organic compounds. Identification and toxicological impact of the by-products. Comptes Rendus Chim 13:494-501. https://doi.org/10.1016/j.crci.2010.01.001

Gennequin C, Siffert S, Cousin R, Aboukaïs A (2009) Co-Mg-Al Hydrotalcite Precursors for Catalytic Total Oxidation of Volatile Organic Compounds. Top Catal 52:482-491. https://doi.org/10.1007/s11244-009-9183-7

Gevers BR, Naseem S, Leuteritz A, Labuschagné FJWJ (2019) Comparison of nano-structured transition metal modified tri-metal MgMAl-LDHs ( $\mathrm{M}=\mathrm{Fe}, \mathrm{Zn}, \mathrm{Cu}, \mathrm{Ni}, \mathrm{Co}$ ) prepared using coprecipitation. RSC Adv 9:28262-28275. https://doi.org/10.1039/C9RA05452A

Gramigni F, Selleri T, Nova I, Tronconi E (2019) Catalyst systems for selective catalytic reduction + NO $x$ trapping: from fundamental understanding of the standard SCR reaction to practical applications for lean exhaust after-treatment. React Chem Eng 4:1165-1178. https://doi.org/10.1039/C9RE00012G

Gunugunuri K, Roberts CA (2019) Direct NOx decomposition catalyst with improved activity and selectivity 
Gunugunuri KR, Peck TC, Ling C, Jia H (2018) Catalyst for direct nox decomposition and a method of forming and using the catalyst

Guo X, Wu Z, He M (2009) Removal of antimony(V) and antimony(III) from drinking water by coagulation-flocculation-sedimentation (CFS). Water Res 43:4327-4335. https://doi.org/10.1016/j.watres.2009.06.033

Guo Z, Chen Y, Lu NL (2018) Multifunctional Nanocomposites for Energy and Environmental Applications. John Wiley \& Sons

Halabi MH, de Croon MHJM, van der Schaaf J, et al (2012a) High capacity potassium-promoted hydrotalcite for $\mathrm{CO} 2$ capture in $\mathrm{H} 2$ production. Int J Hydrog Energy 37:4516-4525. https://doi.org/10.1016/j.ijhydene.2011.12.003

Halabi MH, de Croon MHJM, van der Schaaf J, et al (2012b) A novel catalyst-sorbent system for an efficient H2 production with in-situ CO2 capture. Int J Hydrog Energy 37:4987-4996. https://doi.org/10.1016/j.ijhydene.2011.12.025

He L, Berntsen H, Chen D (2010) Approaching Sustainable $\mathrm{H}_{2}$ Production: Sorption Enhanced Steam Reforming of Ethanol ${ }^{\dagger}$. J Phys Chem A 114:3834-3844. https://doi.org/10.1021/jp906146y

He L, Berntsen H, Ochoa-Fernández E, et al (2009) Co-Ni Catalysts Derived from Hydrotalcite-Like Materials for Hydrogen Production by Ethanol Steam Reforming. Top Catal 52:206-217. https://doi.org/10.1007/s11244-008-9157-1

Helwani Z, Othman MR, Aziz N, et al (2009) Technologies for production of biodiesel focusing on green catalytic techniques: A review. Fuel Process Technol 90:1502-1514. https://doi.org/10.1016/j.fuproc.2009.07.016

Hibino T, Ohya H (2009) Synthesis of crystalline layered double hydroxides: Precipitation by using urea hydrolysis and subsequent hydrothermal reactions in aqueous solutions. Appl Clay Sci 45:123-132. https://doi.org/10.1016/j.clay.2009.04.013

Homsi D, Rached JA, Aouad S, et al (2017) Steam reforming of ethanol for hydrogen production over $\mathrm{Cu} / \mathrm{Co}-\mathrm{Mg}$-Al-based catalysts prepared by hydrotalcite route. Environ Sci Pollut Res 24:99079913. https://doi.org/10.1007/s11356-016-7480-9

Imanaka N, Masui T (2012) Advances in direct NOx decomposition catalysts. Appl Catal Gen 431432:1-8. https://doi.org/10.1016/j.apcata.2012.02.047

Inayat A, Klumpp M, Schwieger W (2011) The urea method for the direct synthesis of ZnAl layered double hydroxides with nitrate as the interlayer anion. Appl Clay Sci 51:452-459. https://doi.org/10.1016/j.clay.2011.01.008

Ishihara S, Sahoo P, Deguchi K, et al (2013) Dynamic Breathing of $\mathrm{CO}_{2}$ by Hydrotalcite. J Am Chem Soc 135:18040-18043. https://doi.org/10.1021/ja4099752

Iyi N, Matsumoto T, Kaneko Y, Kitamura K (2004) Deintercalation of Carbonate lons from a Hydrotalcite-Like Compound: Enhanced Decarbonation Using Acid-Salt Mixed Solution. Chem Mater 16:2926-2932. https://doi.org/10.1021/cm049579g 
Jang HJ, Lee $\mathrm{CH}$, Kim S, et al (2014) Hydrothermal Synthesis of $\mathrm{K}_{2} \mathrm{CO}_{3}$-Promoted Hydrotalcite from Hydroxide-Form Precursors for Novel High-Temperature $\mathrm{CO}_{2}$ Sorbent. ACS Appl Mater Interfaces 6:6914-6919. https://doi.org/10.1021/am500720f

Jiang Y, Ling J, Xiao P, et al (2018) Simultaneous biogas purification and CO2 capture by vacuum swing adsorption using zeolite NaUSY. Chem Eng J 334:2593-2602. https://doi.org/10.1016/j.cej.2017.11.090

Jitianu M, Soiu ML, Zaharescu M, et al (2000) Comparative Study of Sol-Gel and Coprecipitated Ni-Al Hydrotalcites. J Sol-Gel Sci Technol 19:453-457

Kamal MS, Razzak SA, Hossain MM (2016) Catalytic oxidation of volatile organic compounds (VOCs) A review. Atmos Environ 140:117-134. https://doi.org/10.1016/j.atmosenv.2016.05.031

Kameda T, Tochinai M, Kumagai S, Yoshioka T (2019a) Simultaneous treatment of HCl-SO2-NOx gas with $\mathrm{Mg}-\mathrm{Al}$ layered double hydroxide intercalated with $\mathrm{CO} 32-$ and its recycling process. Int J Environ Sci Technol. https://doi.org/10.1007/s13762-019-02529-7

Kameda T, Tochinai M, Kumagai S, Yoshioka T (2020) Simultaneous treatment of HCl-SO2-NOx gas with $\mathrm{Mg}-\mathrm{Al}$ layered double hydroxide intercalated with $\mathrm{CO} 32-$ and its recycling process. Int J Environ Sci Technol 17:1179-1184. https://doi.org/10.1007/s13762-019-02529-7

Kameda T, Tochinai M, Kumagai S, Yoshioka T (2019b) Treatment of NOx using recyclable CO32-intercalated Mg-Al layered double hydroxide. Atmospheric Pollut Res 10:1866-1872. https://doi.org/10.1016/j.apr.2019.07.018

Kameda T, Uchiyama N, Yoshioka T (2011) Removal of $\mathrm{HCl}$, SO2, and NO by treatment of acid gas with $\mathrm{Mg}-\mathrm{Al}$ oxide slurry. Chemosphere 82:587-591. https://doi.org/10.1016/j.chemosphere.2010.11.020

Kannan S, Rives V, Knözinger H (2004) High-temperature transformations of Cu-rich hydrotalcites. J Solid State Chem 177:319-331. https://doi.org/10.1016/j.jssc.2003.08.023

Kannan S, Velu S, Ramkumar V, Swamy CS (1995) Synthesis and physicochemical properties of cobalt aluminium hydrotalcites. J Mater Sci 30:1462-1468. https://doi.org/10.1007/BF00375249

Karickhoff SW (1984) Organic Pollutant Sorption in Aquatic Systems. J Hydraul Eng 110:707-735. https://doi.org/10.1061/(ASCE)0733-9429(1984)110:6(707)

Klemkaite K, Prosycevas I, Taraskevicius R, et al (2011) Synthesis and characterization of layered double hydroxides with different cations ( $\mathrm{Mg}, \mathrm{Co}, \mathrm{Ni}, \mathrm{Al})$, decomposition and reformation of mixed metal oxides to layered structures. Cent Eur J Chem 9:275-282. https://doi.org/10.2478/s11532-011-0007-9

Kloprogge JT, Hickey L, Frost RL (2004) The effects of synthesis $\mathrm{pH}$ and hydrothermal treatment on the formation of zinc aluminum hydrotalcites. J Solid State Chem 177:4047-4057. https://doi.org/10.1016/j.jssc.2004.07.010

Kloprogge JT, Hickey L, Trujillano R, et al (2006) Characterization of Intercalated Ni/Al Hydrotalcites Prepared by the Partial Decomposition of Urea. Cryst Growth Des 6:1533-1536. https://doi.org/10.1021/cg0504612 
Kovanda F, Grygar T, Dorničák V, et al (2005a) Thermal behaviour of Cu-Mg-Mn and Ni-Mg-Mn layered double hydroxides and characterization of formed oxides. Appl Clay Sci 28:121-136. https://doi.org/10.1016/j.clay.2004.01.007

Kovanda F, Jirátová K (2011a) Supported layered double hydroxide-related mixed oxides and their application in the total oxidation of volatile organic compounds. Appl Clay Sci 53:305-316. https://doi.org/10.1016/j.clay.2010.12.030

Kovanda F, Jirátová K (2011b) Supported mixed oxide catalysts for the total oxidation of volatile organic compounds. Catal Today 176:110-115. https://doi.org/10.1016/j.cattod.2011.02.002

Kovanda F, Koloušek D, Cílová Z, Hulínský V (2005b) Crystallization of synthetic hydrotalcite under hydrothermal conditions. Appl Clay Sci 28:101-109. https://doi.org/10.1016/j.clay.2004.01.009

Koyuncu I (2002) Reactive dye removal in dye/salt mixtures by nanofiltration membranes containing vinylsulphone dyes: effects of feed concentration and cross flow velocity. Desalination 143:243-253. https://doi.org/10.1016/S0011-9164(02)00263-1

Labuschagné FJWJ, Wiid A, Venter HP, et al (2018) Green synthesis of hydrotalcite from untreated magnesium oxide and aluminum hydroxide. Green Chem Lett Rev 11:18-28. https://doi.org/10.1080/17518253.2018.1426791

Lau W-J, Ismail AF (2009) Polymeric nanofiltration membranes for textile dye wastewater treatment: Preparation, performance evaluation, transport modelling, and fouling control - a review. Desalination 245:321-348. https://doi.org/10.1016/j.desal.2007.12.058

Lee G, Kang JY, Yan N, et al (2016) Simple preparation method for Mg-Al hydrotalcites as base catalysts. J Mol Catal Chem 423:347-355. https://doi.org/10.1016/j.molcata.2016.07.018

Lehmann M, Zouboulis Al, Matis KA (1999) Removal of metal lons from dilute aqueous solutions: A comparative study of inorganic sorbent materials. Chemosphere 39:881-892. https://doi.org/10.1016/S0045-6535(99)00031-4

Leinonen H, Lehto J, Mäkelä A (1994) Purification of nickel and zinc from waste waters of metalplating plants by ion exchange. React Polym 23:221-228. https://doi.org/10.1016/09231137(94)90024-8

León M, Díaz E, Bennici S, et al (2010) Adsorption of $\mathrm{CO}_{2}$ on Hydrotalcite-Derived Mixed Oxides: Sorption Mechanisms and Consequences for Adsorption Irreversibility. Ind Eng Chem Res 49:3663-3671. https://doi.org/10.1021/ie902072a

Li B, Zhang Y, Zhou X, et al (2016) Different dye removal mechanisms between monodispersed and uniform hexagonal thin plate-like MgAl-CO32--LDH and its calcined product in efficient removal of Congo red from water. J Alloys Compd 673:265-271. https://doi.org/10.1016/j.jallcom.2016.02.248

Li D, Wang L, Koike $\mathrm{M}$, et al (2011) Steam reforming of tar from pyrolysis of biomass over $\mathrm{Ni} / \mathrm{Mg} / \mathrm{Al}$ catalysts prepared from hydrotalcite-like precursors. Appl Catal B Environ 102:528-538. https://doi.org/10.1016/j.apcatb.2010.12.035 
Li LD, Yu JJ, Hao ZP, Xu ZP (2007) Novel Ru-Mg-Al-O Catalyst Derived from Hydrotalcite-like Compound for NO Storage/Decomposition/Reduction. J Phys Chem C 111:10552-10559. https://doi.org/10.1021/jp0678352

Li S, Guo Y, Xiao M, et al (2019a) Enhanced arsenate removal from aqueous solution by Mn-doped MgAl-layered double hydroxides. Environ Sci Pollut Res 26:12014-12024. https://doi.org/10.1007/s11356-019-04667-4

Li X, Du Y, Guo X, et al (2019b) Synthesis of a Novel NiMnTi Mixed Metal Oxides from LDH Precursor and Its Catalytic Application for Selective Catalytic Reduction of NOx with NH3. Catal Lett 149:456-464. https://doi.org/10.1007/s10562-018-2626-7

Li Z, Chen F, Yuan L, et al (2012) Uranium(VI) adsorption on graphene oxide nanosheets from aqueous solutions. Chem Eng J 210:539-546. https://doi.org/10.1016/j.cej.2012.09.030

Liao L, Zhao N, Xia Z (2012) Hydrothermal synthesis of Mg-Al layered double hydroxides (LDHs) from natural brucite and $\mathrm{Al}(\mathrm{OH}) 3$. Mater Res Bull 47:3897-3901. https://doi.org/10.1016/j.materresbull.2012.07.007

Lin Y, Wang X, Hao J, et al (2019) Preparation of CuZnAl hydrotalcite-like catalysts for AsH3 abatement at low temperatures. Catal Commun 118:51-55. https://doi.org/10.1016/j.catcom.2018.03.028

Lopez T, Bosch P, Asomoza M, et al (1997a) DTA-TGA and FTIR spectroscopies of sol-gel hydrotalcites: aluminum source effect on physicochemical properties. Mater Lett 31:311-316

Lopez T, Bosch P, Ramos E, et al (1996) Synthesis and Characterization of Sol-Gel Hydrotalcites. Structure and Texture ${ }^{\dagger}$. Langmuir 12:189-192. https://doi.org/10.1021/la940703s

Lopez T, Ramos E, Bosch P, et al (1997b) DTA and TGA characterization of sol-gel hydrotalcites. Mater Lett 30:279-282. https://doi.org/10.1016/S0167-577X(96)00214-5

Lourvanij K, Rorrer GL (1994) Dehydration of glucose to organic acids in microporous pillared clay catalysts. Appl Catal Gen 109:147-165. https://doi.org/10.1016/0926-860X(94)85008-9

Lukyanov DB, Sill G, d'Itri JL, Hall WK (1995) Comparison of Catalyzed and Homogeneous Reactions of Hydrocarbons for Selective Catalytic Reduction (SCR) of NOx. J Catal 153:265-274

Lv L, He J, Wei M, et al (2006) Factors influencing the removal of fluoride from aqueous solution by calcined Mg-Al-CO3 layered double hydroxides. J Hazard Mater 133:119-128. https://doi.org/10.1016/j.jhazmat.2005.10.012

Mahmoud R, Moaty SA, Mohamed F, Farghali A (2017) Comparative Study of Single and Multiple Pollutants System Using Ti-Fe Chitosan LDH Adsorbent with High Performance in Wastewater Treatment. J Chem Eng Data 62:3703-3722. https://doi.org/10.1021/acs.jced.7b00453

Mahzoul H, Brilhac JF, Gilot P (1999) Experimental and mechanistic study of NOx adsorption over NOx trap catalysts. Appl Catal B Environ 20:47-55. https://doi.org/10.1016/S09263373(98)00093-9 
Mao G, Tamaura Y (1993) SYNTHESIS A N D CO2 ADSORPTION FEATURES OF A HYDROTALCITE-LIKE COMPOUND OF THE Mg2+-A13+-Fe(CN)6 4- SYSTEM WITH HIGH LAYER-CHARGE DENSITY. Clays Clay Miner 41:7

Marquevich M, Medina F, Montan D (2001) Hydrogen production via steam reforming of sun`ower oil over $\mathrm{Ni} / \mathrm{Al}$ catalysts from hydrotalcite materials. Catal Commun 6

Mathieu Y, Tzanis L, Soulard M, et al (2013) Adsorption of SOx by oxide materials: A review. Fuel Process Technol 114:81-100. https://doi.org/10.1016/j.fuproc.2013.03.019

Mazur LP, Pozdniakova TA, Mayer DA, et al (2016) Design of a fixed-bed ion-exchange process for the treatment of rinse waters generated in the galvanization process using Laminaria hyperborea as natural cation exchanger. Water Res 90:354-368. https://doi.org/10.1016/j.watres.2015.12.027

Megías-Sayago C, Bingre R, Huang L, et al (2019) CO2 Adsorption Capacities in Zeolites and Layered Double Hydroxide Materials. Front Chem 7:551. https://doi.org/10.3389/fchem.2019.00551

Mikulová Z, Čuba P, Balabánová J, et al (2007) Calcined Ni-Al layered double hydroxide as a catalyst for total oxidation of volatile organic compounds: Effect of precursor crystallinity. Chem Pap 61:. https://doi.org/10.2478/s11696-007-0006-7

Milutinović-Nikolić A, Maksin D, Jović-Jovičić N, et al (2014) Removal of 99Tc(VII) by organo-modified bentonite. Appl Clay Sci 95:294-302. https://doi.org/10.1016/j.clay.2014.04.027

Miyata S (1975) The Syntheses of Hydrotalcite-like Compounds and their Structures and Physicochemical Properties I. The Systems Mg2+-Al3+-NO3-, Mg2+-Al3+-Cl-, Mg2+-Al3+-ClO4-, Ni2+$\mathrm{Al} 3+-\mathrm{Cl}$ - and $\mathrm{Zn2+-Al3+-Cl-.} \mathrm{Clays} \mathrm{Clay} \mathrm{Miner} \mathrm{23:369-375}$

Miyata S (1980) Physico-Chemical Properties of Synthetic Hydrotalcites in Relation to Composition. Clays Clay Miner 28:50-56. https://doi.org/10.1346/CCMN.1980.0280107

Montañez MK, Molina R, Moreno S (2014) Nickel catalysts obtained from hydrotalcites by coprecipitation and urea hydrolysis for hydrogen production. Int J Hydrog Energy 39:82258237. https://doi.org/10.1016/j.ijhydene.2014.03.103

Moreira RFPM, Soares JL, Casarin GL, Rodrigues AE (2006) Adsorption of CO 2 on Hydrotalcite-like Compounds in a Fixed Bed. Sep Sci Technol 41:341-357. https://doi.org/10.1080/01496390500496827

Mrad R, Cousin R, Saliba NA, et al (2015) Degradation of VOCs and NOx over Mg(Cu)-AlFe mixed oxides derived from hydrotalcite-like compounds. Comptes Rendus Chim 18:351-357. https://doi.org/10.1016/j.crci.2014.08.005

Naseem S, Gevers B, Boldt R, et al (2019) Comparison of transition metal (Fe, Co, Ni, Cu, and Zn) containing tri-metal layered double hydroxides (LDHs) prepared by urea hydrolysis. RSC Adv 9:3030-3040. https://doi.org/10.1039/C8RA10165E

Ogawa M, Asai S (2000) Hydrothermal Synthesis of Layered Double Hydroxide-Deoxycholate Intercalation Compounds. Chem Mater 12:3253-3255. https://doi.org/10.1021/cm000455n 
Othman MR, Rasid NM, Fernando WJN (2006) Effects of thermal treatment on the micro-structures of co-precipitated and sol-gel synthesized (Mg-Al) hydrotalcites. Microporous Mesoporous Mater 93:23-28. https://doi.org/10.1016/j.micromeso.2006.02.007

Özacar M, Şengil IA (2002) Adsorption of Acid Dyes from Aqueous Solutions by Calcined Alunite and Granular Activated Carbon. Adsorption 8:301-308. https://doi.org/10.1023/A:1021585413857

Palacio LA, Velásquez J, Echavarría A, et al (2010) Total oxidation of toluene over calcined trimetallic hydrotalcites type catalysts. J Hazard Mater 177:407-413. https://doi.org/10.1016/j.jhazmat.2009.12.048

Palomares A, Lopez-Nieto JM, Lazaro FJ, et al (1999) Reactivity in the removal of SO2 and NOx on $\mathrm{Co} / \mathrm{Mg} / \mathrm{Al}$ mixed oxides derived from hydrotalcites. Appl Catal B Environ 20:257-266. https://doi.org/10.1016/S0926-3373(98)00121-0

Paredes SP, Fetter G, Bosch P, Bulbulian S (2006) Sol-gel synthesis of hydrotalcite - like compounds. J Mater Sci 41:3377-3382. https://doi.org/10.1007/s10853-005-5347-4

Park S, Kwon D, Kang JY, Jung JC (2018) Influence of the preparation method on the catalytic activity of $\mathrm{Mg}$ Al hydrotalcites as solid base catalysts. Green Energy Environ. https://doi.org/10.1016/j.gee.2018.11.003

Pavan PC, Crepaldi EL, de A. Gomes G, Valim JB (1999) Adsorption of sodium dodecylsulfate on a hydrotalcite-like compound. Effect of temperature, $\mathrm{pH}$ and ionic strength. Colloids Surf Physicochem Eng Asp 154:399-410. https://doi.org/10.1016/S0927-7757(98)00847-4

Pavan PC, Crepaldi EL, Valim JB (2000) Sorption of Anionic Surfactants on Layered Double Hydroxides. J Colloid Interface Sci 229:346-352. https://doi.org/10.1006/jcis.2000.7031

Perez-Lopez OW, Senger A, Marcilio NR, Lansarin MA (2006) Effect of composition and thermal pretreatment on properties of $\mathrm{Ni}-\mathrm{Mg}-\mathrm{Al}$ catalysts for $\mathrm{CO} 2$ reforming of methane. Appl Catal Gen 303:234-244. https://doi.org/10.1016/j.apcata.2006.02.024

Pinnavaia TJ, Amarasekera J, Polansky CA (1991) Process using sorbents for the removal of sox from flue gas and other gas streams

Pinnavaia TJ, Amarasekera J, Polansky CA (1992) Process using sorbents for the removal of SOx from flue gas

Prince J, Montoya A, Ferrat G, Valente JS (2009) Proposed General Sol-Gel Method to Prepare Multimetallic Layered Double Hydroxides: Synthesis, Characterization, and Envisaged Application. Chem Mater 21:5826-5835. https://doi.org/10.1021/cm902741c

Prinetto F, Ghiotti G, Graffin P, Tichit D (2000) Synthesis and characterization of sol-gel Mg/Al and $\mathrm{Ni} /$ Al layered double hydroxides and comparison with co-precipitated samples. Microporous Mesoporous Mater 39:229-247. https://doi.org/10.1016/S1387-1811(00)00197-9

Radha S, Navrotsky A (2014) Energetics of $\mathrm{CO}_{2}$ Adsorption on Mg-Al Layered Double Hydroxides and Related Mixed Metal Oxides. J Phys Chem C 118:29836-29844. https://doi.org/10.1021/jp508678k 
Rahmanian O, Dinari M, Neamati S (2018) Synthesis and characterization of citrate intercalated layered double hydroxide as a green adsorbent for $\mathrm{Ni2}+$ and $\mathrm{Pb} 2+$ removal. Environ Sci Pollut Res 25:36267-36277. https://doi.org/10.1007/s11356-018-3584-8

Ram Reddy MK, Xu ZP, Diniz da Costa JC (2008) Influence of Water on High-Temperature $\mathrm{CO}_{2}$ Capture Using Layered Double Hydroxide Derivatives. Ind Eng Chem Res 47:2630-2635. https://doi.org/10.1021/ie0716060

Ram Reddy MK, Xu ZP, Lu GQ (Max), Diniz da Costa JC (2006) Layered Double Hydroxides for $\mathrm{CO}_{2}$ Capture: Structure Evolution and Regeneration. Ind Eng Chem Res 45:7504-7509. https://doi.org/10.1021/ie060757k

Ramírez-Moreno MJ, Romero-Ibarra IC, Hernández-Pérez MA, Pfeiffer H (2014) $\mathrm{CO}_{2}$ Adsorption at Elevated Pressure and Temperature on Mg-Al Layered Double Hydroxide. Ind Eng Chem Res 53:8087-8094. https://doi.org/10.1021/ie5010515

Ramos E, Lopez T, Bosch P, et al (1997) Thermal stability of sol-gel hydrotalcites. J Sol-Gel Sci Technol 8:437-442. https://doi.org/10.1007/BF02436879

Ramos-Ramírez E, Ortega NLG, Soto CAC, Gutiérrez MTO (2009) Adsorption isotherm studies of chromium (VI) from aqueous solutions using sol-gel hydrotalcite-like compounds. J Hazard Mater 172:1527-1531. https://doi.org/10.1016/j.jhazmat.2009.08.023

Rao MM, Reddy BR, Jayalakshmi M, et al (2005) Hydrothermal synthesis of Mg-Al hydrotalcites by urea hydrolysis. Mater Res Bull 40:347-359. https://doi.org/10.1016/j.materresbull.2004.10.007

Roelofs JCAA, Lensveld DJ, van Dillen AJ, de Jong KP (2001) On the Structure of Activated Hydrotalcites as Solid Base Catalysts for Liquid-Phase Aldol Condensation. J Catal 203:184191. https://doi.org/10.1006/jcat.2001.3295

Rosatella AA, Simeonov SP, Frade RFM, Afonso CAM (2011) 5-Hydroxymethylfurfural (HMF) as a building block platform: Biological properties, synthesis and synthetic applications. Green Chem 13:754. https://doi.org/10.1039/c0gc00401d

Rubí H, Fall C, Ortega RE (2009) Pollutant removal from oily wastewater discharged from car washes through sedimentation-coagulation. Water Sci Technol 59:2359-2369. https://doi.org/10.2166/wst.2009.307

Sakano M, Kawamura S (2018) Method for producing NOx storage-reduction catalyst

Sato T, Fujita H, Endo T, Shimada M (1988) Synthesis Of Hydrotalcite-Like Compounds And Their Physico-Chemical Properties. React Solids 5:219-228

Sedlmair Ch, Seshan K, Jentys A, Lercher JA (2003) Elementary steps of NOx adsorption and surface reaction on a commercial storage-reduction catalyst. J Catal 214:308-316. https://doi.org/10.1016/S0021-9517(02)00085-4

Seftel EM, Niarchos M, Mitropoulos Ch, et al (2015) Photocatalytic removal of phenol and methylene-blue in aqueous media using TiO2@LDH clay nanocomposites. Catal Today 252:120-127. https://doi.org/10.1016/j.cattod.2014.10.030 
Seki Y, Yurdakoç K (2005) Paraquat adsorption onto clays and organoclays from aqueous solution. J Colloid Interface Sci 287:1-5. https://doi.org/10.1016/j.jcis.2004.10.072

Shan R, Yan L, Yang K, et al (2014) Magnetic Fe304/MgAl-LDH composite for effective removal of three red dyes from aqueous solution. Chem Eng J 252:38-46. https://doi.org/10.1016/j.cej.2014.04.105

Sharma SK, Kushwaha PK, Srivastava VK, et al (2007) Effect of Hydrothermal Conditions on Structural and Textural Properties of Synthetic Hydrotalcites of Varying Mg/Al Ratio. Ind Eng Chem Res 46:4856-4865. https://doi.org/10.1021/ie061438w

Sheng T, Zhang Z, Hu Y, et al (2019) Adsorption of phosphorus by using magnetic Mg-Al-, Zn-Al- and $\mathrm{Mg}-\mathrm{Fe}-\mathrm{layered}$ double hydroxides: comparison studies and adsorption mechanism. Environ Sci Pollut Res 26:7102-7114. https://doi.org/10.1007/s11356-019-04191-5

Sikander U, Samsudin MF, Sufian S, et al (2018) Tailored hydrotalcite-based Mg-Ni-Al catalyst for hydrogen production via methane decomposition: Effect of nickel concentration and spinellike structures. Int J Hydrog Energy. https://doi.org/10.1016/j.ijhydene.2018.10.224

Sikander U, Sufian S, Salam MA (2017) A review of hydrotalcite based catalysts for hydrogen production systems. Int J Hydrog Energy 42:19851-19868. https://doi.org/10.1016/j.ijhydene.2017.06.089

Silletti BA, Adams RT, Sigmon SM, et al (2006) A novel Pd/MgAlOx catalyst for NOx storage-reduction. Catal Today 114:64-71. https://doi.org/10.1016/j.cattod.2006.02.003

Silva JM, Trujillano R, Rives V, et al (2017) High temperature CO 2 sorption over modified hydrotalcites. Chem Eng J 325:25-34. https://doi.org/10.1016/j.cej.2017.05.032

Smalenskaite A, Vieira DEL, Salak AN, et al (2017) A comparative study of co-precipitation and sol-gel synthetic approaches to fabricate cerium-substituted $\mathrm{Mg}$ Al layered double hydroxides with luminescence properties. Appl Clay Sci 143:175-183. https://doi.org/10.1016/j.clay.2017.03.036

Solovov VA, Nikolenko NV, Kovalenko VL, et al (2018) Synthesis of Ni(II)-Ti(IV) Layered Double Hydroxides using Coprecipitation at High Supersaturation Method. J Eng Appl Sci 13:96529656

Song W, Wang X, Wang Q, et al (2015) Plasma-induced grafting of polyacrylamide on graphene oxide nanosheets for simultaneous removal of radionuclides. Phys Chem Chem Phys 17:398-406. https://doi.org/10.1039/C4CP04289A

Sun Y, Wang X, Ai Y, et al (2017) Interaction of sulfonated graphene oxide with U(VI) studied by spectroscopic analysis and theoretical calculations. Chem Eng J 310:292-299. https://doi.org/10.1016/j.cej.2016.10.122

Tanasoi S, Tanchoux N, Urdă A, et al (2009) New Cu-based mixed oxides obtained from LDH precursors, catalysts for methane total oxidation. Appl Catal Gen 363:135-142. https://doi.org/10.1016/j.apcata.2009.05.007

Tang N, He T, Liu J, et al (2018) New Insights into CO2 Adsorption on Layered Double Hydroxide (LDH)-Based Nanomaterials. Nanoscale Res Lett 13:. https://doi.org/10.1186/s11671-0182471-z 

Zn-A1 HYDROTALCITE-LIKE COMPOUNDS. Clays Clay Miner 37:7

Thomas N (2012) Mechanochemical synthesis of layered hydroxy salts. Mater Res Bull 47:3568-3572. https://doi.org/10.1016/j.materresbull.2012.06.057

Thouchprasitchaia N, Pintuyothin N, Pongstabodee S (2018) Optimization of CO2 adsorption capacity and cyclical adsorption/desorption on tetraethylenepentamine-supported surface-modified hydrotalcite. J Environ Sci 65:293-305. https://doi.org/10.1016/j.jes.2017.02.015

Tichit D, Rolland A, Prinetto F, et al (2002) Comparison of the structural and acid-base properties of Ga- and Al-containing layered double hydroxides obtained by microwave irradiation and conventional ageing of synthesis gels. J Mater Chem 12:3832-3838. https://doi.org/10.1039/B203376N

Tsuji M, Mao G, Yoshida T, Tamaura Y (1993) Hydrotalcites with an extended Al3+-substitution: Synthesis, simultaneous TG-DTA-MS study, and their $\mathrm{CO} 2$ adsorption behaviors. J Mater Res 8:1137-1142. https://doi.org/10.1557/JMR.1993.1137

Tzompantzi F, Mantilla A, Bañuelos F, et al (2011) Improved Photocatalytic Degradation of Phenolic Compounds With ZnAl Mixed Oxides Obtained from LDH Materials. Top Catal 54:257-263. https://doi.org/10.1007/s11244-011-9656-3

Ulibarri M (2001) Adsorption of anionic species on hydrotalcite-like compounds: effect of interlayer anion and crystallinity. Appl Clay Sci 18:17-27. https://doi.org/10.1016/S01691317(00)00026-0

Umeno T, Hanzama M, Hayashi Y (2019) NOx storage reduction catalyst for purifying exhaust gas and exhaust gas purification method using said catalyst

Valeikiene L, Paitian R, Grigoraviciute-Puroniene I, et al (2019) Transition metal substitution effects in sol-gel derived Mg3-xMx/Al1 ( $\mathrm{M}=\mathrm{Mn}, \mathrm{Co}, \mathrm{Ni}, \mathrm{Cu}, \mathrm{Zn}$ ) layered double hydroxides. Mater Chem Phys 237:121863. https://doi.org/10.1016/j.matchemphys.2019.121863

Valente JS, Cantú MS, Cortez JGH, et al (2007) Preparation and Characterization of Sol-Gel MgAl Hydrotalcites with Nanocapsular Morphology. J Phys Chem C 111:642-651. https://doi.org/10.1021/jp065283h

Valente JS, Lima E, Toledo-Antonio JA, et al (2010) Comprehending the Thermal Decomposition and Reconstruction Process of Sol-Gel MgAl Layered Double Hydroxides. J Phys Chem C 114:2089-2099. https://doi.org/10.1021/jp910538r

Valente JS, Prince J, Maubert AM, et al (2009) Physicochemical Study of Nanocapsular Layered Double Hydroxides Evolution. J Phys Chem C 113:5547-5555. https://doi.org/10.1021/jp810293y

Valente JS, Quintana-Solorzano R (2011) Novel SOx removal catalysts for the FCC process: Manufacture method, characterization, and pilot-scale testing. Energy Environ Sci 4:4096. https://doi.org/10.1039/c1ee01197a

van Putten R-J, van der Waal JC, de Jong E, et al (2013) Hydroxymethylfurfural, A Versatile Platform Chemical Made from Renewable Resources. Chem Rev 113:1499-1597. https://doi.org/10.1021/cr300182k 
Vierheilig A (2003) Compounds, compositions and methods to reduce SOx emissions from FCC units

Wan S, Wang S, Li Y, Gao B (2017) Functionalizing biochar with Mg-Al and Mg-Fe layered double hydroxides for removal of phosphate from aqueous solutions. J Ind Eng Chem 47:246-253. https://doi.org/10.1016/j.jiec.2016.11.039

Wang J, Stevens LA, Drage TC, et al (2012a) Preparation and CO2 adsorption of amine modified layered double hydroxide via anionic surfactant-mediated route. Chem Eng J 181-182:267275. https://doi.org/10.1016/j.cej.2011.11.078

Wang J, Stevens LA, Drage TC, Wood J (2012b) Preparation and CO2 adsorption of amine modified Mg-AI LDH via exfoliation route. Chem Eng Sci 68:424-431. https://doi.org/10.1016/j.ces.2011.09.052

Wang Q, Tay HH, Ng DJW, et al (2010) The Effect of Trivalent Cations on the Performance of Mg-MCO3 Layered Double Hydroxides for High-Temperature CO2 Capture. ChemSusChem 3:965973. https://doi.org/10.1002/cssc.201000099

Wang R, Wu X, Zou C, et al (2018) NOx Removal by Selective Catalytic Reduction with Ammonia over a Hydrotalcite-Derived NiFe Mixed Oxide. Catalysts 8:384. https://doi.org/10.3390/catal8090384

Wang X, Sun Y, Alsaedi A, et al (2015) Interaction mechanism of Eu(III) with MX-80 bentonite studied by batch, TRLFS and kinetic desorption techniques. Chem Eng J 264:570-576. https://doi.org/10.1016/j.cej.2014.11.136

Wang Y, Du T, Liu L, et al (2017) A Review of Layered Double Hydroxides as Intermediatetemperature CO2 Adsorbents. In: Proceedings of the 2017 6th International Conference on Energy, Environment and Sustainable Development (ICEESD 2017). Atlantis Press, Zhuhai, China

Wang Z, Liu F, Lu C (2011) Mg-Al-carbonate layered double hydroxides as a novel catalyst of luminol chemiluminescence. Chem Commun 47:5479. https://doi.org/10.1039/c1cc10520e

Wu L, Peng B, Li Q, et al (2019a) Formation of high crystalline LDH sludge for removing Cu and Zn from wastewater by controlled double-jet precipitation. Environ Sci Pollut Res 26:1966519675. https://doi.org/10.1007/s11356-019-05161-7

Wu X, Wang $\mathrm{R}$, Du $\mathrm{Y}$, et al (2019b) NO ${ }_{x}$ removal by selective catalytic reduction with ammonia over hydrotalcite-derived NiTi mixed oxide. New J Chem 43:2640-2648. https://doi.org/10.1039/C8NJ05280H

Wu Y-J, Li P, Yu J-G, et al (2013) K-Promoted Hydrotalcites for $\mathrm{CO}_{2}$ Capture in Sorption Enhanced Reactions. Chem Eng Technol 36:567-574. https://doi.org/10.1002/ceat.201200694

Xu S, Liao M, Zeng H, et al (2016) Preparation Behavior of the Mg-Fe Hydrotalcite by Urea Method and Its $\mathrm{Cr}(\mathrm{VI})$ Sorption Property. J Nanosci Nanotechnol 16:3122-3131. https://doi.org/10.1166/jnn.2016.12411

Xu ZP, Lu GQ (Max) (2005) Hydrothermal Synthesis of Layered Double Hydroxides (LDHs) from Mixed $\mathrm{MgO}$ and $\mathrm{Al}_{2} \mathrm{O}_{3}$ : LDH Formation Mechanism. Chem Mater 17:1055-1062. https://doi.org/10.1021/cm048085g 
Xu ZP, Zhang J, Adebajo MO, et al (2011) Catalytic applications of layered double hydroxides and derivatives. Appl Clay Sci 53:139-150. https://doi.org/10.1016/j.clay.2011.02.007

Xue L, Gao B, Wan Y, et al (2016) High efficiency and selectivity of MgFe-LDH modified wheat-straw biochar in the removal of nitrate from aqueous solutions. J Taiwan Inst Chem Eng 63:312317. https://doi.org/10.1016/j.jtice.2016.03.021

Yang D, Song S, Zou Y, et al (2017) Rational design and synthesis of monodispersed hierarchical SiO 2 @layered double hydroxide nanocomposites for efficient removal of pollutants from aqueous solution. Chem Eng J 323:143-152. https://doi.org/10.1016/j.cej.2017.03.158

Yang L, Shahrivari Z, Liu PKT, et al (2005) Removal of Trace Levels of Arsenic and Selenium from Aqueous Solutions by Calcined and Uncalcined Layered Double Hydroxides (LDH). Ind Eng Chem Res 44:6804-6815. https://doi.org/10.1021/ie049060u

Yang P, Yu J, Wang Z, et al (2004) Urea method for the synthesis of hydrotalcites. React Kinet Catal Lett 83:275-282. https://doi.org/10.1023/B:REAC.0000046087.86802.c2

Yang R, Gao Y, Wang J, Wang Q (2014) Layered double hydroxide (LDH) derived catalysts for simultaneous catalytic removal of soot and NOx. Dalton Trans 43:10317. https://doi.org/10.1039/c3dt52896k

Yang S, Ren X, Zhao G, et al (2015) Competitive sorption and selective sequence of $\mathrm{Cu}$ (II) and $\mathrm{Ni}(\mathrm{II})$ on montmorillonite: Batch, modeling, EPR and XAS studies. Geochim Cosmochim Acta 166:129145. https://doi.org/10.1016/j.gca.2015.06.020

Yang Z, Choi K-M, Jiang N, Park S-E (2007) Microwave Synthesis of Hydrotalcite by Urea Hydrolysis. Bull Korean Chem Soc 28:2029-2033

Yang Z, Wei J, Zeng G, et al (2019) A review on strategies to LDH-based materials to improve adsorption capacity and photoreduction efficiency for CO2. Coord Chem Rev 386:154-182. https://doi.org/10.1016/j.ccr.2019.01.018

Yokomichi Y, Nakayama T, Okada O, et al (1996) Fundamental study on the NOx direct decomposition catalysts. Catal Today 29:155-160. https://doi.org/10.1016/0920-5861(95)00252-9

Yong Z, Mata V, Rodrigues A (2002) Adsorption of carbon dioxide at high temperature-a review. Sep Purif Technol 26:195-205. https://doi.org/10.1016/S1383-5866(01)00165-4

Yoo JS, Bhattacharyya AA, Radlowski CA, Karch JA (1992) Advanced De-SOx catalyst: Mixed solid solution spinels with cerium oxide. Appl Catal B Environ 1:169-189. https://doi.org/10.1016/0926-3373(92)80022-R

Yu J, Cheng J, Ma C, et al (2009) NOx decomposition, storage and reduction over novel mixed oxide catalysts derived from hydrotalcite-like compounds. J Colloid Interface Sci 333:423-30. https://doi.org/10.1016/j.jcis.2009.02.022

Yu JJ, Jiang Z, Zhu L, et al (2006) Adsorption/Desorption Studies of NO $x$ on Well-Mixed Oxides Derived from Co-Mg/Al Hydrotalcite-like Compounds. J Phys Chem B 110:4291-4300. https://doi.org/10.1021/jp056473f 
Yu JJ, Wang XP, Tao YX, et al (2007) Effective NO ${ }_{x}$ Decomposition and Storage/Reduction over Mixed Oxides Derived from Layered Double Hydroxides. Ind Eng Chem Res 46:5794-5797. https://doi.org/10.1021/ie0705958

Yu S, Wang X, Chen Z, et al (2017) Layered double hydroxide intercalated with aromatic acid anions for the efficient capture of aniline from aqueous solution. J Hazard Mater 321:111-120. https://doi.org/10.1016/j.jhazmat.2016.09.009

Yu Y, Li X, Krishna R, et al (2018) Enhancing $\mathrm{CO}_{2}$ Adsorption and Separation Properties of Aluminophosphate Zeolites by Isomorphous Heteroatom Substitutions. ACS Appl Mater Interfaces 10:43570-43577. https://doi.org/10.1021/acsami.8b11235

Zakrzewska ME, Bogel-Łukasik E, Bogel-Łukasik R (2011) lonic Liquid-Mediated Formation of 5Hydroxymethylfurfural-A Promising Biomass-Derived Building Block. Chem Rev 111:397417. https://doi.org/10.1021/cr100171a

Zardin L, Perez-Lopez OW (2017) Hydrogen production by methane decomposition over Co-Al mixed oxides derived from hydrotalcites: Effect of the catalyst activation with $\mathrm{H} 2$ or $\mathrm{CH} 4$. Int J Hydrog Energy 42:7895-7907. https://doi.org/10.1016/j.ijhydene.2017.02.153

Zeng H-Y, Deng X, Wang Y-J, Liao K-B (2009a) Preparation of Mg-Al hydrotalcite by urea method and its catalytic activity for transesterification. AIChE J 55:1229-1235. https://doi.org/10.1002/aic.11722

Zeng W, Cheng D, Chen F, Zhan X (2009b) Catalytic Conversion of Glucose on Al-Zr Mixed Oxides in Hot Compressed Water. Catal Lett 133:221-226. https://doi.org/10.1007/s10562-009-0160-3

Zepp RG, Schlotzhauer PF (1981) Effects of equilibration time on photoreactivity of the pollutant DDE sorbed on natural sediments. Chemosphere 10:453-460. https://doi.org/10.1016/00456535(81)90145-4

Zhang WH, Guo XD, He J, Qian ZY (2008) Preparation of Ni(II)/Ti(IV) layered double hydroxide at high supersaturation. J Eur Ceram Soc 28:1623-1629. https://doi.org/10.1016/j.jeurceramsoc.2007.11.016

Zhang Z-Q, Liao M-C, Zeng H-Y, et al (2014) Mg-Al hydrotalcites as solid base catalysts for alcoholysis of propylene oxide. Fuel Process Technol 128:519-524. https://doi.org/10.1016/j.fuproc.2014.08.015

Zhao P, Liu X, Tian W, et al (2015) Adsolubilization of 2,4,6-trichlorophenol from aqueous solution by surfactant intercalated ZnAl layered double hydroxides. Chem Eng J 279:597-604. https://doi.org/10.1016/j.cej.2015.05.037

Zhao R, Yin C, Zhao H, Liu C (2003) Synthesis, characterization, and application of hydotalcites in hydrodesulfurization of FCC gasoline. Fuel Process Technol 81:201-209. https://doi.org/10.1016/S0378-3820(03)00012-2

Zou Y, Wang X, Ai Y, et al (2016a) Coagulation Behavior of Graphene Oxide on Nanocrystallined $\mathrm{Mg} / \mathrm{Al}$ Layered Double Hydroxides: Batch Experimental and Theoretical Calculation Study. Environ Sci Technol 50:3658-3667. https://doi.org/10.1021/acs.est.6b00255 
Adsorption of atmospheric pollutants $\mathrm{CO}_{2}, \mathrm{NOx}, \mathrm{SOx}, \mathrm{VOCs} .$.
5-Hydroxymethylfurfural production

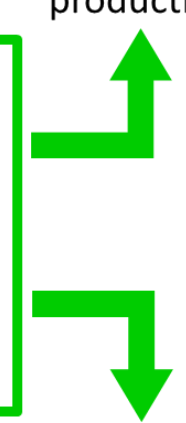

Hydrogen production

Adsorption of aqueous pollutants

Heavy metals, drugs...

Fig1. Environmental applications of hydrotalcites discussed in this review.

Fig2. Scheme of the co-precipitation method applied to the LDHs synthesis.

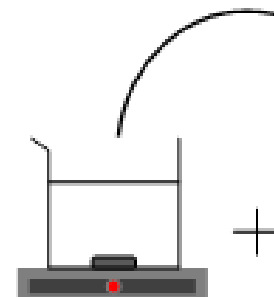

Magnesium

+ aluminum sources

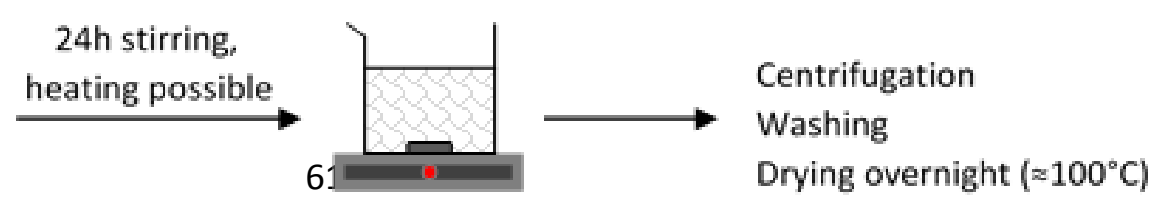

(+ carbonate source) 


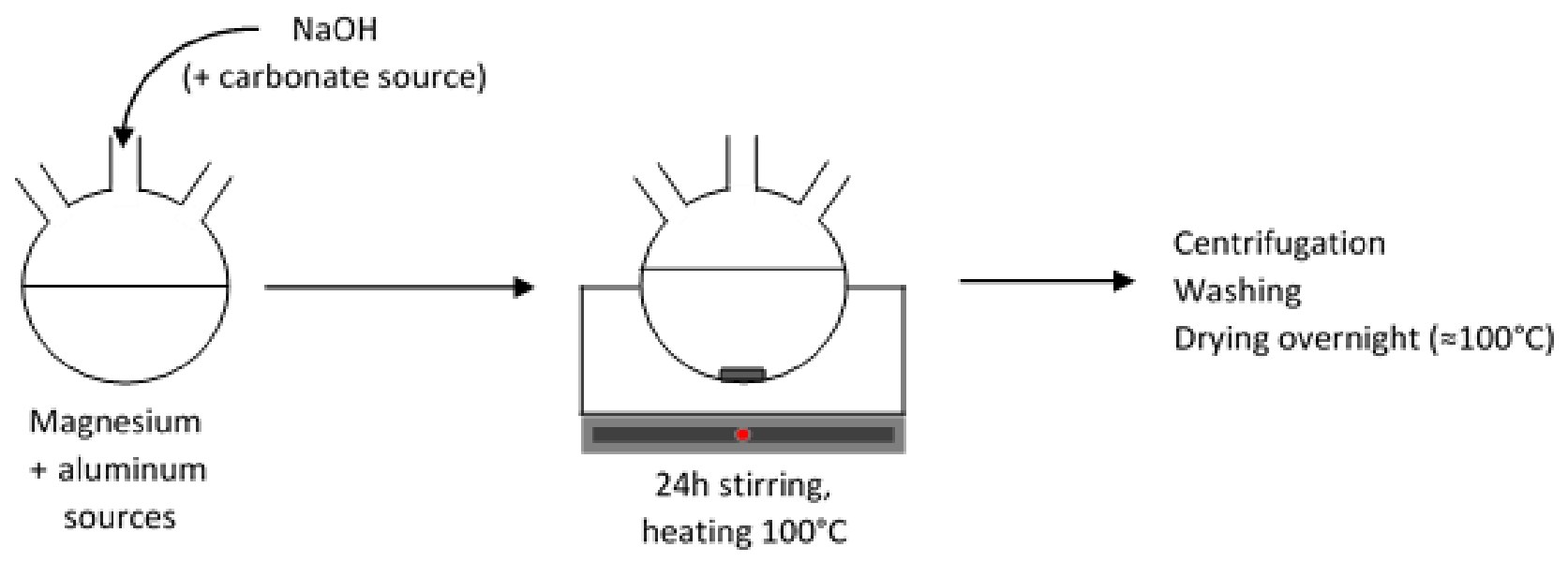

1748 Fig3. Scheme of the synthesis of hydrotalcites via urea hydrolysis.

Magnesium source

+ Ethanol
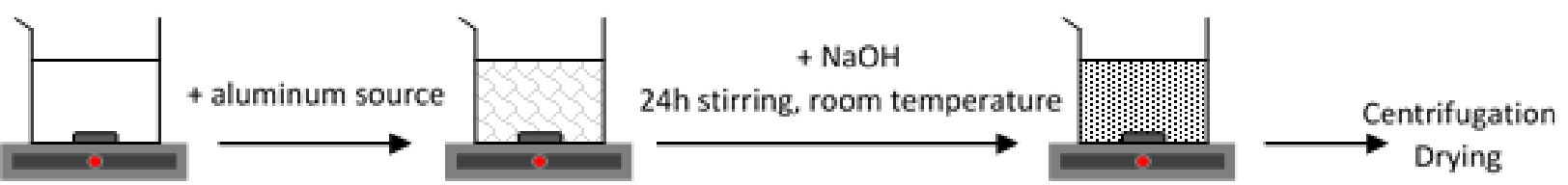

1749

1750 Fig4. Scheme of the synthesis of hydrotalcites by sol-gel process.

Magnesium source

+ aluminum source

+ ethanol

$+\mathrm{NaOH}$

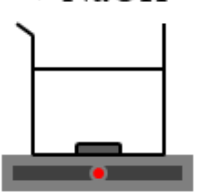

Put the solution in a stainless steel reactor

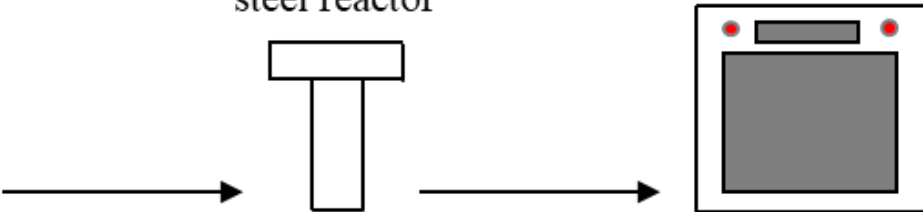

Heating $100-300^{\circ} \mathrm{C}$

Autogenous-high pressure Hours to days

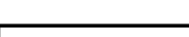

Centrifugation Drying

1752 Fig5. Hydrothermal synthesis process applied to hydrotalcite synthesis.

1753

1754 Table 1. Main structural and textural impacts of different synthesis processes on LDHs. 


\begin{tabular}{|c|c|c|}
\hline Synthesis method & Advantages & Drawbacks \\
\hline Co-precipitation & $\begin{array}{l}\text { - High crystallinity } \\
\text { with post-treatment } \\
\text { - } \quad \text { Easy insertion of } \\
\text { metallic elements }\end{array}$ & $\begin{array}{l}\text { - } \quad \text { Large Particles (formation of } \\
\text { aggregates) } \\
\text { - } \quad \text { Low specific surface area }\end{array}$ \\
\hline Use of urea & 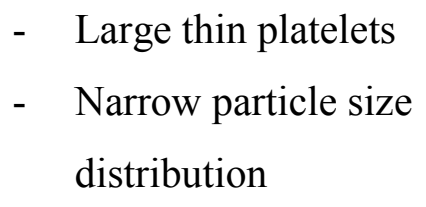 & $\begin{array}{l}\text { - Formation of } \mathrm{CO}_{2} \text { by urea } \\
\text { decomposition, formation of } \\
\text { carbonates as counter-anions }\end{array}$ \\
\hline Sol-gel & $\begin{array}{ll}\text { - } & \text { High homogeneity } \\
\text { - } & \text { High purity } \\
\text { - } & \text { Small particles } \\
& \text { (nanoscale) }=\text { high } \\
& \text { specific surface area } \\
\text { - } & \text { Short times (hours) }\end{array}$ & $\begin{array}{l}\text { - Low crystallinity } \\
\text { - Additional treatments required } \\
\text { (microwave irradiation, } \\
\text { ultrasonication, or } \\
\text { hydrothermal treatment) }\end{array}$ \\
\hline Hydrothermal & $\begin{array}{ll}\text { - } & \text { Increases } \\
\text { crystallinity } \\
\text { - } \quad \text { Increases particle } \\
\text { size } \\
\text { - } & \text { Increases purity }\end{array}$ & $\begin{array}{l}\text { - High energy (heating) and time } \\
\text { (hours to days) demand } \\
\text { - More efficient as an additional } \\
\text { treatment of other synthesis } \\
\text { methods }\end{array}$ \\
\hline
\end{tabular}

Table 2. Synthesis parameters of the LDHs and mixed oxides cited in the part "2.1.1. $\mathrm{CO}_{2}$ adsorption - Capture and storage".

\begin{tabular}{l|l|c|c|l}
\hline \multicolumn{1}{c|}{ Reference } & $\begin{array}{c}\text { Type of } \\
\text { material }\end{array}$ & $\begin{array}{c}\text { Surface area } \\
\left(\mathrm{m}^{2} \cdot \mathrm{g}^{-1}\right)\end{array}$ & $\begin{array}{c}\text { Adsorption } \\
\text { capacity } \\
\left(\mathrm{mmol.g} \mathbf{g}^{-1}\right)\end{array}$ & $\begin{array}{c}\text { Synthesis method / } \\
\text { structural modifications }\end{array}$ \\
\hline $\begin{array}{l}\text { Mao and Tamaura } \\
\mathbf{1 9 9 3}\end{array}$ & MgAlFe LDH & - & - & $\begin{array}{l}\text { Co-precipitation at } \\
\text { various } \mathrm{Al} / \mathrm{Mg}+\mathrm{Al}) \\
\text { molar ratios. }\end{array}$ \\
\hline Tsuji et al. 1993 & Various LDHs & - & - & $\begin{array}{l}\text { Co-precipitation with } \\
\text { change of the } \mathrm{M}(\mathrm{II}) \\
\text { cations: } \mathrm{Mg}^{2+}, \mathrm{Ni}^{2+}, \mathrm{Zn}^{2+}, \\
\mathrm{Co}^{2+} .\end{array}$ \\
\hline
\end{tabular}




\begin{tabular}{|c|c|c|c|c|}
\hline Wang et al. 2010 & $\begin{array}{l}\mathrm{Mg}-\mathrm{M}(\mathrm{III}) \\
\mathrm{LDHs}\end{array}$ & $82.4-148.6$ & $0.050-0.462$ & $\begin{array}{l}\text { Co-precipitation with } \\
\text { change of the } \mathrm{M}(\mathrm{III}) \\
\text { cations: } \mathrm{Al}^{3+}, \mathrm{Ga}^{3+}, \mathrm{Fe}^{3+} \text {, } \\
\mathrm{Mn}^{3+}, \mathrm{Cr}^{3+}, \mathrm{Ce}^{3+}, \mathrm{La}^{3+}\end{array}$ \\
\hline $\begin{array}{l}\text { Ram Reddy et al. } \\
2006\end{array}$ & $\begin{array}{l}\text { Calcined } \\
\text { MgAl LDHs }\end{array}$ & $63-167$ & $0.231-0.486$ & $\begin{array}{l}\text { Co-precipitation and } \\
\text { calcination at different } \\
\text { temperatures from } 200 \text { to } \\
600^{\circ} \mathrm{C} \text { for } 4 \mathrm{~h} .\end{array}$ \\
\hline $\begin{array}{l}\text { Ram Reddy et al. } \\
2008\end{array}$ & $\begin{array}{l}\text { Calcined } \\
\text { MgAl LDHs }\end{array}$ & - & - & $\begin{array}{l}\text { Co-precipitation and } \\
\text { calcination at } 400^{\circ} \mathrm{C} \text { for } \\
4 \mathrm{~h} .\end{array}$ \\
\hline $\begin{array}{l}\text { Dadwhal et al. } \\
2008\end{array}$ & $\begin{array}{l}\text { Calcined } \\
\text { MgAl LDHs }\end{array}$ & - & 0.7 & $\begin{array}{l}\text { Co-precipitation and } \\
\text { calcination at } 500^{\circ} \mathrm{C} \text { for } \\
4 \mathrm{~h} \text {. }\end{array}$ \\
\hline León et al. 2010 & $\begin{array}{l}\text { Calcined } \\
\text { MgAl LDHs }\end{array}$ & $62-190$ & $0.4-1.15$ & $\begin{array}{l}\text { Co-precipitation at low } \\
\text { and high supersaturation } \\
\text { and calcination at } 450 \text { or } \\
700^{\circ} \mathrm{C} \text { for } 7 \mathrm{~h} \text {. Anion } \\
\text { exchange by } \mathrm{K}^{+} \text {or } \mathrm{Na}^{+} \\
\text {prior the calcination. }\end{array}$ \\
\hline Gao et al. 2013 & $\begin{array}{l}\text { Calcined } \\
\text { MgAl LDHs }\end{array}$ & $154-239$ & $0.30-0.72$ & $\begin{array}{l}\text { Co-precipitation followed } \\
\text { by hydrothermal } \\
\text { treatment at } 120^{\circ} \mathrm{C} \text { for } 6 \mathrm{~h} \text {, } \\
\text { urea method, or urea } \\
\text { decomposition followed } \\
\text { by microwave irradiation } \\
\text { at } 120^{\circ} \mathrm{C} 200 \mathrm{~W} \text { for } \\
30 \mathrm{~min} \text {. }\end{array}$ \\
\hline $\begin{array}{l}\text { Ramírez-Moreno } \\
\text { et al. } 2014\end{array}$ & $\mathrm{MgAl} \mathrm{LDHs}$ & $136.6-296.3$ & $0.2-0.75$ & $\begin{array}{l}\text { Co-precipitation at low } \\
\text { supersaturation. }\end{array}$ \\
\hline Bhatta et al. 2015 & $\begin{array}{l}\text { MgAl LDH } \\
\text { supported in } \\
\text { coal-derived } \\
\text { graphitic } \\
\text { material }\end{array}$ & $41-219.6$ & $0.48-1.10$ & $\begin{array}{l}\text { Co-precipitation at low } \\
\text { supersaturation. }\end{array}$ \\
\hline
\end{tabular}




\begin{tabular}{l|l|l|l|l}
\hline Dantas et al. 2015 & $\begin{array}{l}\text { MgAl LDHs } \\
\text { expanded with } \\
\text { a polymer }\end{array}$ & $50.1-61.1$ & $0.72-1.36$ & $\begin{array}{l}\text { Co-precipitation at low } \\
\text { supersaturation. }\end{array}$ \\
\hline Tang et al. 2018 & $\begin{array}{l}\text { MgAl LDHs } \\
\text { enlarged by } \\
\text { SDS ions } \\
\text { before } \\
\text { grafting 3- }\end{array}$ & - & $1.55-2.09$ & $\begin{array}{l}\text { Co-precipitation at high } \\
\text { supersaturation. }\end{array}$ \\
\hline Thouchprasitchaia \\
et al. 2018
\end{tabular}




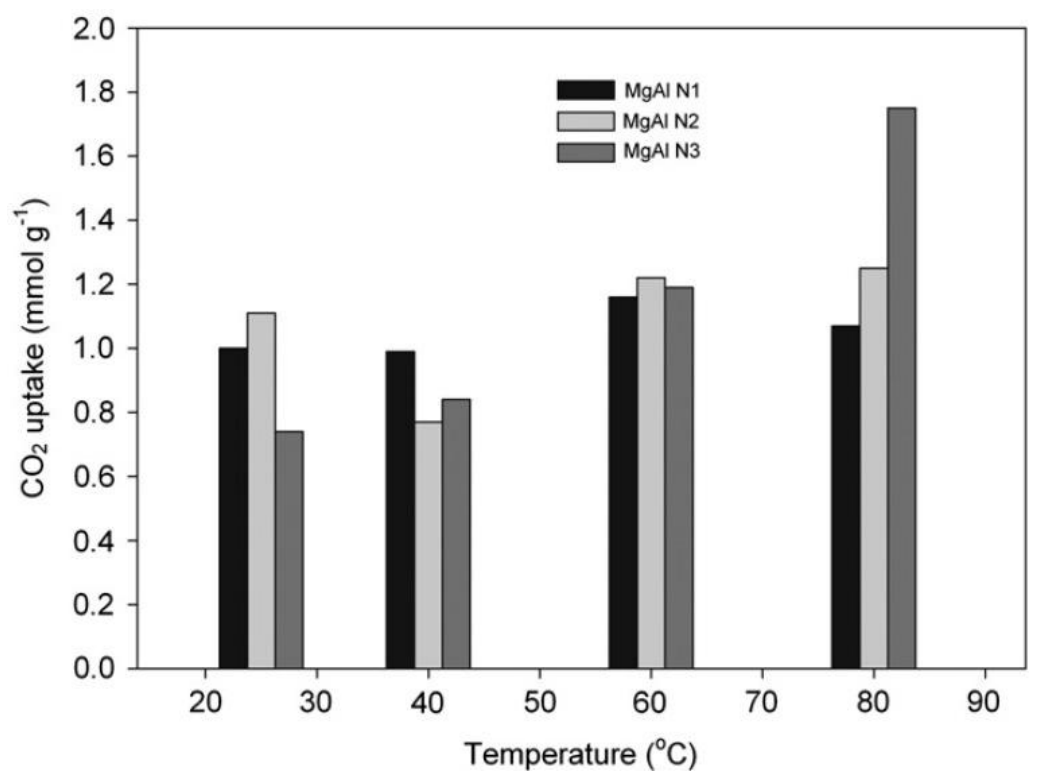

1758

1759 Fig6. $\mathrm{CO}_{2}$ adsorption by amine-modified $\mathrm{MgAl}$ hydrotalcites at different temperatures (from 1760 Wang et al. (2012b)).

Table 3. $\mathrm{CO}_{2}$ adsorption by several types of hydrotalcites according to literature.

\begin{tabular}{c|c|c|c|c}
\hline $\begin{array}{c}\text { M(II)/M(III) } \\
\text { molar ratio }\end{array}$ & $\begin{array}{c}\mathbf{C O}_{2} \text { adsorbed } \\
\left(\mathbf{m m o l . g} \mathbf{g}^{-1}\right.\end{array}$ & $\begin{array}{c}\text { Synthesis } \\
\text { process }\end{array}$ & $\begin{array}{c}\text { Modifications / } \\
\text { improvements }\end{array}$ & References \\
\hline 3 & 0.5 & $\begin{array}{c}\text { Co- } \\
\text { precipitation }\end{array}$ & - & $\begin{array}{c}\text { Ram Reddy et al. } \\
\mathbf{2 0 0 6}\end{array}$ \\
\hline 2.87 & 0.7 & $\begin{array}{c}\text { Co- } \\
\text { precipitation }\end{array}$ & - & $\begin{array}{c}\text { Dadwhal et al. } \\
\mathbf{2 0 0 8}\end{array}$ \\
\hline $2-3$ & $0.7-1.5$ & $\begin{array}{c}\text { Co- } \\
\text { precipitation }\end{array}$ & - & $\begin{array}{c}\text { Albuquerque et al. } \\
\mathbf{2 0 1 6}\end{array}$ \\
\hline $1-5$ & $0.4-1.5$ & $\begin{array}{c}\text { Co- } \\
\text { precipitation }\end{array}$ & Fe-promoted & $\begin{array}{c}\text { Mao and Tamaura } \\
\mathbf{1 9 9 3}\end{array}$ \\
\hline 1.2 & $0.15-0.6$ & $\begin{array}{c}\text { Co- } \\
\text { precipitation }\end{array}$ & Different M(II) cations & Tsuji et al. 1993 \\
\hline 3 & $0.6-1.15$ & $\begin{array}{c}\text { Co- } \\
\text { precipitation }\end{array}$ & K- or Na-promoted & León et al. 2010 \\
\hline
\end{tabular}




\begin{tabular}{c|c|c|c|c}
\hline 3 & 1.31 & Hydrothermal & K-promoted & Jang et al. 2014 \\
\hline 2 & $0.42-1.10$ & $\begin{array}{c}\text { Co- } \\
\text { precipitation }\end{array}$ & K-promoted & Bhatta et al. 2015 \\
\hline 2 & 2.09 & $\begin{array}{c}\text { Co- } \\
\text { precipitation }\end{array}$ & $\begin{array}{c}\text { K-promoted + Ga } \\
\text { substitution }\end{array}$ & Silva et al. 2017 \\
\hline 3 & 2.1 & $\begin{array}{c}\text { Co- } \\
\text { precipitation }\end{array}$ & TEPA-supported & $\begin{array}{c}\text { Thouchprasitchaia } \\
\text { et al. 2018 }\end{array}$ \\
\hline $2-3$ & 2.04 & $\begin{array}{c}\text { Co- } \\
\text { precipitation }\end{array}$ & $\begin{array}{c}\text { (3-AP)triethoxysilane- } \\
\text { grafted }\end{array}$ & Tang et al. 2018 \\
\hline
\end{tabular}

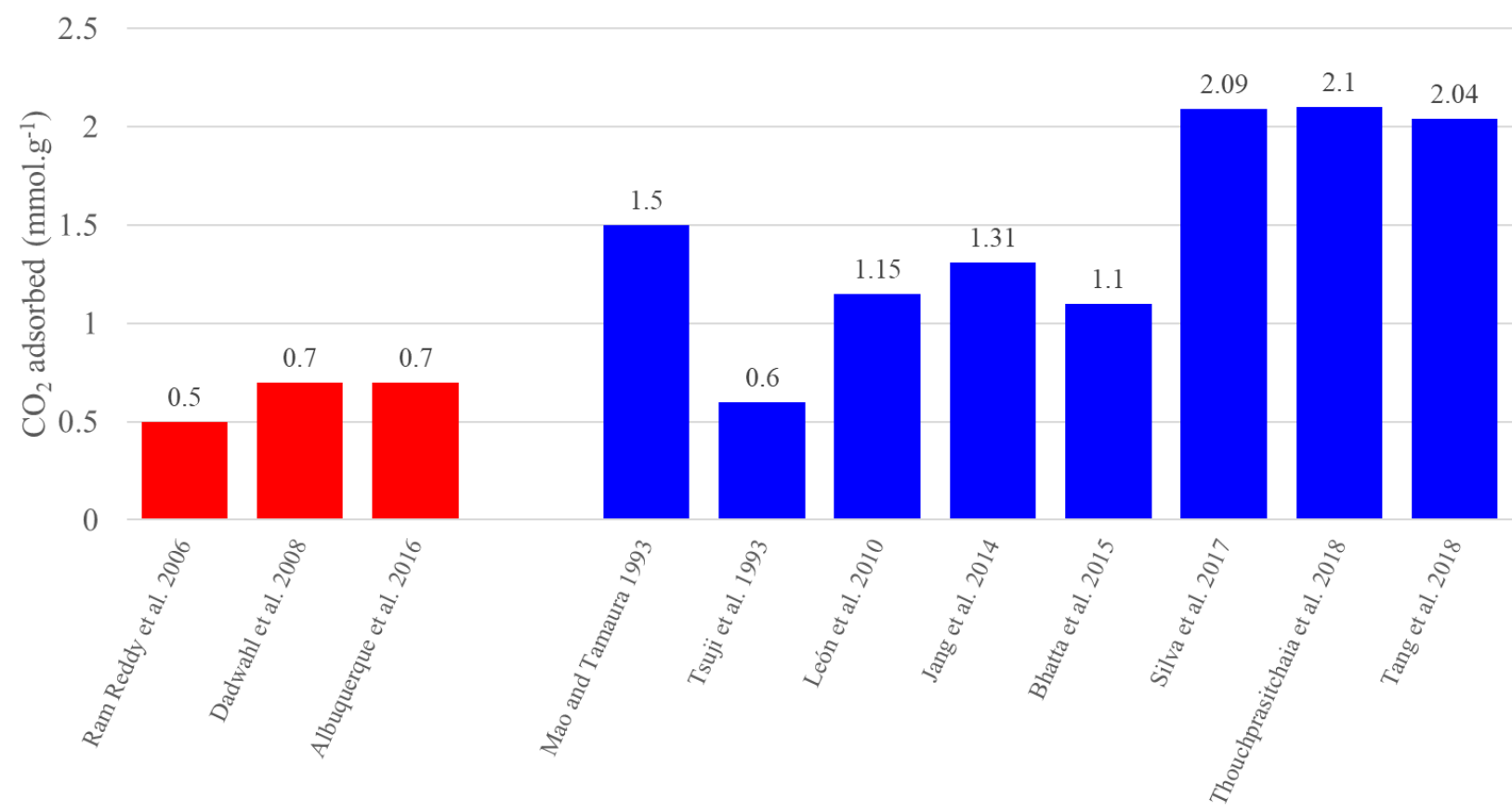

Fig7. Comparison between non-modified (red) and modified (blue) hydrotalcites and derived materials on the $\mathrm{CO}_{2}$ sorption capacity, according to Table 3 .

Table 4. Synthesis conditions of the LDHs and mixed oxides cited in the part "2.1.2. NOx and SOx adsorption".

\begin{tabular}{l|l|l|l|l}
\hline Reference & Type of & Surface area & Adsorption capacity & Synthesis method / \\
\hline
\end{tabular}




\begin{tabular}{|c|c|c|c|c|}
\hline & material & $\left(\mathrm{m}^{2} \cdot \mathrm{g}^{-1}\right)$ & $\left(\mathrm{mmol.g} \mathrm{g}^{-1}\right)$ & structural modifications \\
\hline $\begin{array}{l}\text { Corma et } \\
\text { al. } 1994\end{array}$ & $\begin{array}{l}\text { Calcined } \\
\text { CuMgAl LDHs }\end{array}$ & - & - & $\begin{array}{l}\text { Co-precipitation with fixed } \\
\mathrm{Mg} / \mathrm{Al} \text { molar ratio at } 3 \text { and } \\
10 \text { molar } \% \mathrm{Cu} \text {, then } \\
\text { calcination at } 750^{\circ} \mathrm{C} \text { for } 3 \mathrm{~h} \text {. }\end{array}$ \\
\hline $\begin{array}{l}\text { Palomares } \\
\text { et al. } 1999\end{array}$ & $\begin{array}{l}\text { Calcined } \\
\text { CuMgAl and } \\
\text { CoMgAl LDHs }\end{array}$ & $117-210$ & - & $\begin{array}{l}\text { Co-precipitation similar to } \\
\text { Corma et al. } 1994 \mathrm{~b} \text {. }\end{array}$ \\
\hline $\begin{array}{l}\text { Yu et al. } \\
2006\end{array}$ & $\begin{array}{l}\text { Calcined } \\
\text { CoMgAl LDHs }\end{array}$ & $21.6-162.7$ & - & $\begin{array}{l}\text { Co-precipitation at low } \\
\text { supersaturation with change } \\
\text { of the } \mathrm{Co} / \mathrm{Mg} \text { molar ratio, } \\
\text { then calcination at } 800^{\circ} \mathrm{C} \\
\text { for } 4 \mathrm{~h} \text {. }\end{array}$ \\
\hline $\begin{array}{l}\text { Yu et al. } \\
2007\end{array}$ & $\begin{array}{l}\text { Calcined } \\
\text { CaCoAl and } \\
\text { CaCiLaAl } \\
\text { LDHs }\end{array}$ & - & $0.602-0.651$ & $\begin{array}{l}\text { Co-precipitation at low } \\
\text { supersaturation, then } \\
\text { calcination at } 800^{\circ} \mathrm{C} \text { for } 4 \mathrm{~h} .\end{array}$ \\
\hline $\begin{array}{l}\text { Cheng et } \\
\text { al. } 2004\end{array}$ & $\begin{array}{l}\text { Calcined MgAl } \\
\text { LDHs } \\
\text { impregnated } \\
\text { with Pt }\end{array}$ & $121-249$ & $0.061-0.505$ & $\begin{array}{l}\text { Co-precipitation at low } \\
\text { supersaturation, then } \\
\text { calcination at } 600^{\circ} \mathrm{C} \text { for } 5 \mathrm{~h} \\
\text { and impregnation with } \\
\mathrm{Pt}\left(\mathrm{NH}_{3}\right)_{4}(\mathrm{OH})_{2} \text {. }\end{array}$ \\
\hline $\begin{array}{l}\text { Silletti et } \\
\text { al. } 2006\end{array}$ & $\begin{array}{l}\text { Pd adsorbed on } \\
\text { calcined } \\
\text { commercial } \\
\text { MgAl LDH }\end{array}$ & $\sim 190$ & $0.003-0.062$ & $\begin{array}{l}\text { Commercial LDH with a } \\
\mathrm{Mg}: \mathrm{Al} \text { molar ratio of } 7: 3 \\
\text { calcined at } 600^{\circ} \mathrm{C} \text {, then } \\
{\left[\mathrm{Pd}(\mathrm{acac})_{2}\right] \text { adsorbed on }} \\
\text { freshly calcined samples. }\end{array}$ \\
\hline $\begin{array}{l}\text { Li et al. } \\
2007\end{array}$ & $\begin{array}{l}\text { Calcined } \\
\text { MgRuAl LDHs }\end{array}$ & 280 & 0.220 & $\begin{array}{l}\text { Co-precipitation at low } \\
\text { supersaturation, then } \\
\text { calcination at } 600^{\circ} \mathrm{C} \text { for } 6 \mathrm{~h} \text {. }\end{array}$ \\
\hline $\begin{array}{l}\text { Cui et al. } \\
2019\end{array}$ & $\begin{array}{l}\text { Calcined } \\
\text { MnMgAl } \\
\text { LDHs }\end{array}$ & $108-144$ & $0.104-0.426$ & $\begin{array}{l}\text { Co-precipitation at low } \\
\text { precipitation assisted by } \\
\text { CTAB, then calcination at } \\
600^{\circ} \mathrm{C} \text { for } 6 \mathrm{~h} \text {. }\end{array}$ \\
\hline
\end{tabular}




\begin{tabular}{l|l|c|c|l}
\hline $\begin{array}{l}\text { Kameda } \\
\text { et al. } \\
\text { 2019a, b }\end{array}$ & MgAl LDHs & - & - & $\begin{array}{l}\text { Co-precipitation at low } \\
\text { supersaturation. }\end{array}$ \\
\hline $\begin{array}{l}\text { Cantú et } \\
\text { al. 2005 }\end{array}$ & $\begin{array}{l}\text { Calcined MgAl } \\
\text { and MgFe } \\
\text { LDHs }\end{array}$ & $74-204$ & - & $\begin{array}{l}\text { Co-precipitation at low } \\
\text { supersaturation. }\end{array}$ \\
\hline
\end{tabular}

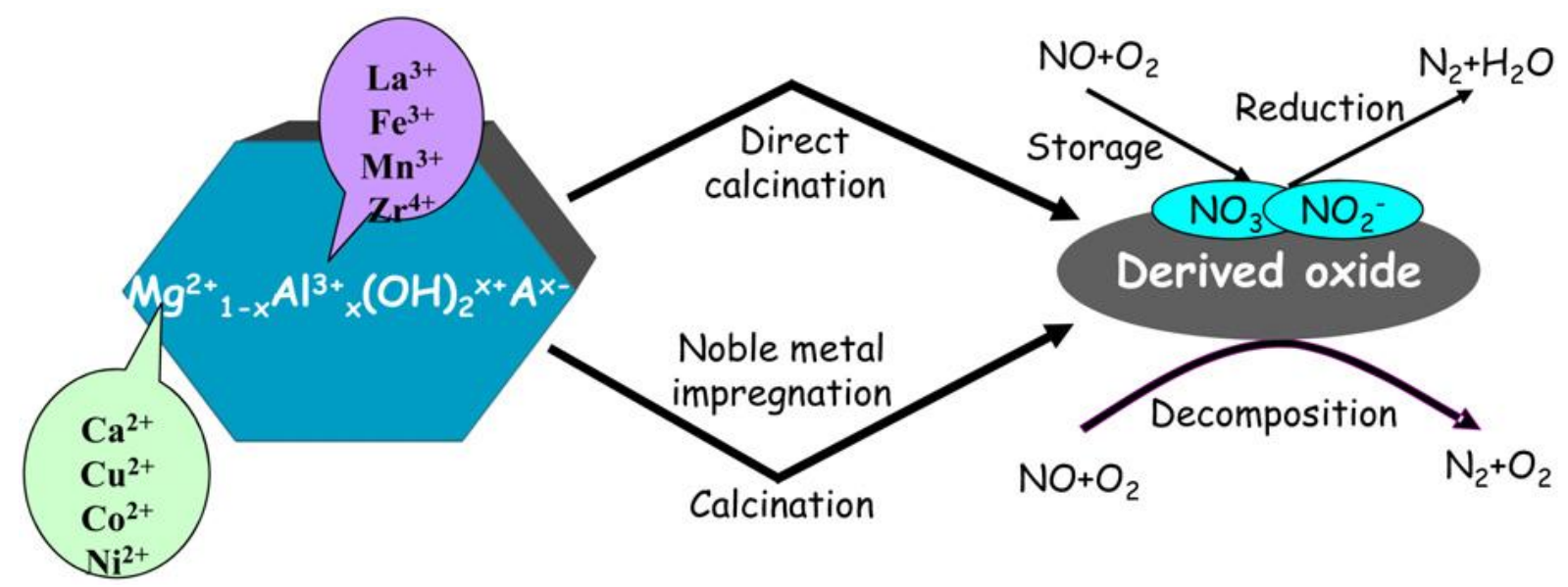

1771 Fig8. Schematic representation of LDH-derived catalysts for NOx storage and reduction 1772 (from Yu et al. 2009). 


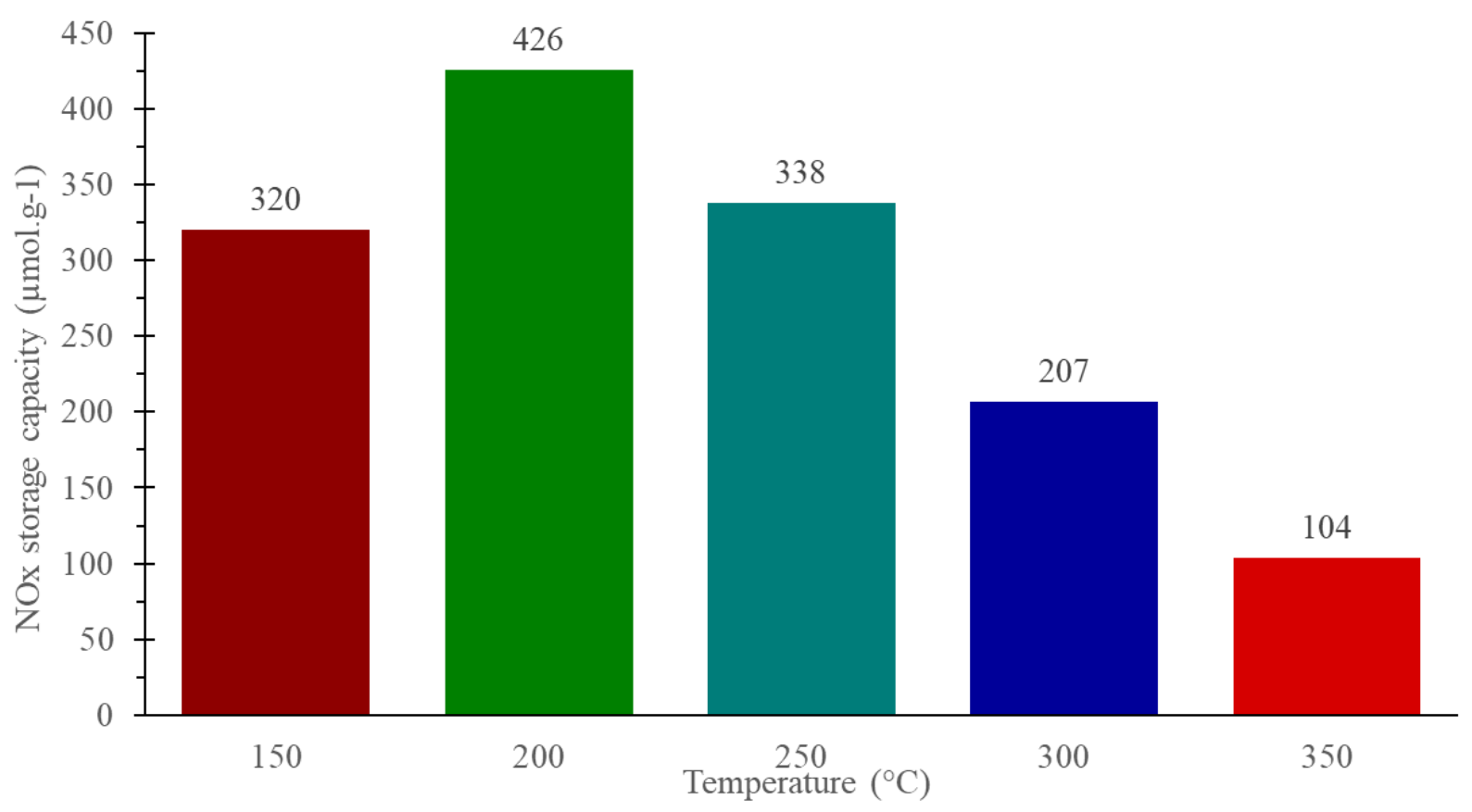

1773

1774 Fig9. NOx storage capacity at different temperatures of mixed oxides derived from $\mathrm{MnMgAl}$

1775 LDHs containing $15 \mathrm{wt} \%$ Mn (from Cui et al. 2019). 


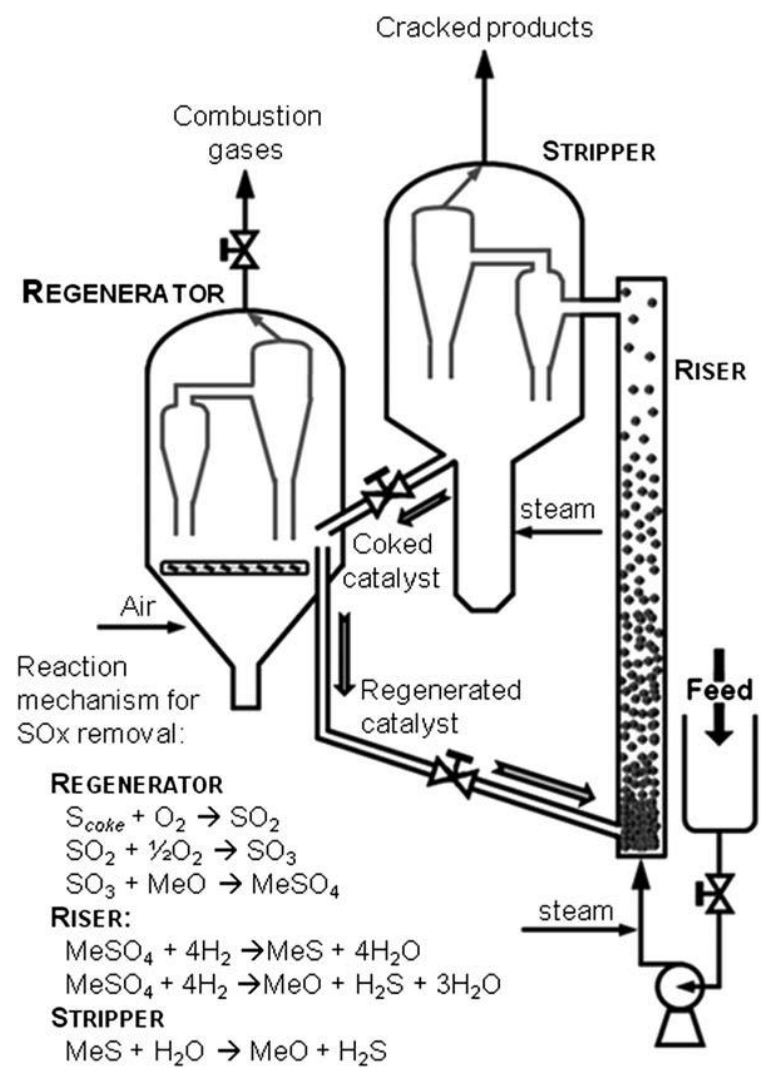

1777 Fig10. Simplified scheme of the Fluid Catalytic Cracking (FCC) process adapted to SOx 1778 removal (from Valente and Quintana-Solorzano 2011).

1779 Table 5. Synthesis parameters of the LDHs and mixed oxides cited in the part "2.1.3. VOCs total decomposition".

\begin{tabular}{|c|c|c|c|}
\hline Reference & Type of material & $\begin{array}{l}\text { Surface area } \\
\qquad\left(\mathrm{m}^{2} \cdot \mathrm{g}^{-1}\right)\end{array}$ & Synthesis method \\
\hline $\begin{array}{l}\text { Bahranowski } \\
\text { et al. } 1999\end{array}$ & $\begin{array}{l}\text { Calcined } \mathrm{CuCr}, \mathrm{ZnCr} \text {, } \\
\text { and } \mathrm{CuAl} \mathrm{LDHs}\end{array}$ & $\begin{array}{c}\text { CuCr-LDHs : } \\
10-20 \\
\text { ZnCr LDH : } \\
41 \\
\text { CuAl LDH : } \\
56\end{array}$ & $\begin{array}{l}\text { Co-precipitation at low supersaturation } \\
\text { and calcination at } 600^{\circ} \mathrm{C} \text { for } 3 \mathrm{~h} \text {. The } \\
\mathrm{CuCr}-\mathrm{LDHs} \text { have been synthesized with } \\
\mathrm{M}(\mathrm{II}): \mathrm{M}(\mathrm{III}) \text { molar ratios of } 1: 1,2: 1 \text {, } \\
\text { and } 3: 1 . \mathrm{ZnCr} \text { and } \mathrm{CuAl} \text { were used to } \\
\text { investigate separately the role of } \mathrm{Cu} \text { and } \\
\mathrm{Cr} \text {. }\end{array}$ \\
\hline $\begin{array}{l}\text { Mikulová et } \\
\text { al. } 2007\end{array}$ & Calcined NiAl LDH & $52-161$ & $\begin{array}{l}\text { Co-precipitation at low supersaturation } \\
\text { and calcination at } 450^{\circ} \mathrm{C} \text { for } 4 \mathrm{~h} \text {. }\end{array}$ \\
\hline
\end{tabular}




\begin{tabular}{|c|c|c|c|}
\hline $\begin{array}{l}\text { Gennequin } \\
\text { et al. 2009, } \\
2010 b\end{array}$ & $\begin{array}{l}\text { Calcined CoMgAl } \\
\text { LDHs }\end{array}$ & $72-141$ & $\begin{array}{l}\text { Co-precipitation at high supersaturation } \\
\text { with varying Co:Mg:Al molar ratio of } \\
6: 0: 2,4: 2: 2,2: 4: 2 \text { and } 0: 6: 2 \text {, and } \\
\text { calcination at } 500^{\circ} \mathrm{C} \text { for } 4 \mathrm{~h} \text {. }\end{array}$ \\
\hline $\begin{array}{l}\text { Gennequin } \\
\text { et al. 2010a }\end{array}$ & $\begin{array}{l}\text { Co-deposited calcined } \\
\text { MgAl LDHs }\end{array}$ & $3-233$ & $\begin{array}{l}\text { Co-precipitation at high supersaturation, } \\
\text { and calcination at different } \\
\text { temperatures: } 500,600,700,800 \text {, and } \\
900^{\circ} \mathrm{C} \text {. Co was then deposited by } \\
\text { aqueous impregnation method. }\end{array}$ \\
\hline $\begin{array}{l}\text { Palacio et al. } \\
2010\end{array}$ & $\begin{array}{l}\text { Calcined } \mathrm{MnCuAl} \text { and } \\
\mathrm{ZnCuAl} \mathrm{LDHs}\end{array}$ & $45-108$ & $\begin{array}{l}\text { Co-precipitation at high supersaturation } \\
\text { and calcination at } 450 \text { and } 600^{\circ} \mathrm{C} \text {. }\end{array}$ \\
\hline $\begin{array}{l}\text { Dula et al. } \\
2007\end{array}$ & $\begin{array}{l}\text { Calcined MgMnAl } \\
\text { LDHs }\end{array}$ & $137-191$ & $\begin{array}{l}\text { Co-precipitation at low supersaturation } \\
\text { and calcination at } 600^{\circ} \mathrm{C} \text { for } 4 \mathrm{~h} .2 \\
\text { different samples have been prepared } \\
\text { with } \mathrm{Mn} \text { either within the structure or in } \\
\text { the ionic form as permanganate anions } \\
\text { in the interlayer space. }\end{array}$ \\
\hline $\begin{array}{l}\text { Tanasoi et } \\
\text { al. } 2009\end{array}$ & $\begin{array}{l}\text { Calcined } \mathrm{CuMgAl} \\
\text { LDHs }\end{array}$ & $114-188$ & $\begin{array}{l}\text { Co-precipitation at low supersaturation } \\
\text { with various copper content from } 1 \text { to } 20 \\
\text { at } \% \text {, and calcination at } 750^{\circ} \mathrm{C} \text { for } 8 \mathrm{~h} \text {. }\end{array}$ \\
\hline $\begin{array}{l}\text { Aguilera et } \\
\text { al. } 2011\end{array}$ & $\begin{array}{l}\text { Calcined MnMgAl, } \\
\text { CuMnMgAl and } \\
\text { CoMnMgAl LDHs }\end{array}$ & $75-249$ & $\begin{array}{l}\text { Co-precipitation at low supersaturation } \\
\text { with varying } \mathrm{Cu} / \mathrm{Mn} \text { and } \mathrm{Co} / \mathrm{Mn} \text { molar } \\
\text { ratios of } 0.5,0.25,0.1 \text {, and } 0.05 \text {, and } \\
\text { calcination at } 500^{\circ} \mathrm{C} \text { for } 16 \mathrm{~h} .\end{array}$ \\
\hline $\begin{array}{l}\text { Chmielarz et } \\
\text { al. } 2012\end{array}$ & $\begin{array}{l}\text { Calcined CuMgAl, } \\
\text { CoMgAl and } \\
\text { CuCoMgAl LDHs }\end{array}$ & $60-217$ & $\begin{array}{l}\text { Co-precipitation at low supersaturation } \\
\text { and calcination at } 700 \text { or } 800^{\circ} \mathrm{C} \text {. The } \\
\text { samples calcined at } 800^{\circ} \mathrm{C} \text { were } \\
\text { modified with potassium using aqueous } \\
\text { impregnation method and calcined again } \\
\text { at } 600^{\circ} \mathrm{C} \text {. }\end{array}$ \\
\hline $\begin{array}{l}\text { Carpentier } \\
\text { et al. } 2002\end{array}$ & $\begin{array}{l}\text { Calcined MgAl LDH } \\
\text { with interlayer Pd } \\
\text { complex }\end{array}$ & $33-69$ & $\begin{array}{l}\text { Co-precipitation at low supersaturation } \\
\text { in presence of } \mathrm{H}_{2} \mathrm{PdCl}_{4} \text { and calcination } \\
\text { at } 290 \text { and } 500^{\circ} \mathrm{C} \text { for } 4 \mathrm{~h} \text {. }\end{array}$ \\
\hline $\begin{array}{l}\text { Kovanda } \\
\text { and Jirátová }\end{array}$ & Several calcined LDHs & $\begin{array}{c}28-150(203 \\
\text { with } \mathrm{Ni})\end{array}$ & $\begin{array}{l}\text { Co-precipitation at low supersaturation } \\
\text { and calcination at } 500^{\circ} \mathrm{C} \text { for } 4 \mathrm{~h} \text {. NiAl, }\end{array}$ \\
\hline
\end{tabular}




\begin{tabular}{l|l|l}
\hline 2011a, b & & $\begin{array}{l}\text { NiMn, CoAl, CoMn, NiCoAl, NiCoMn, } \\
\text { NiCuAl, NiCuMn, CoCuAl, and } \\
\text { CoCuMn have been obtained in order to } \\
\text { compare with similar mixed oxides } \\
\text { deposited on } \mathrm{Al}_{2} \mathrm{O}_{3} / \mathrm{Al} \text { support. }\end{array}$ \\
\hline
\end{tabular}

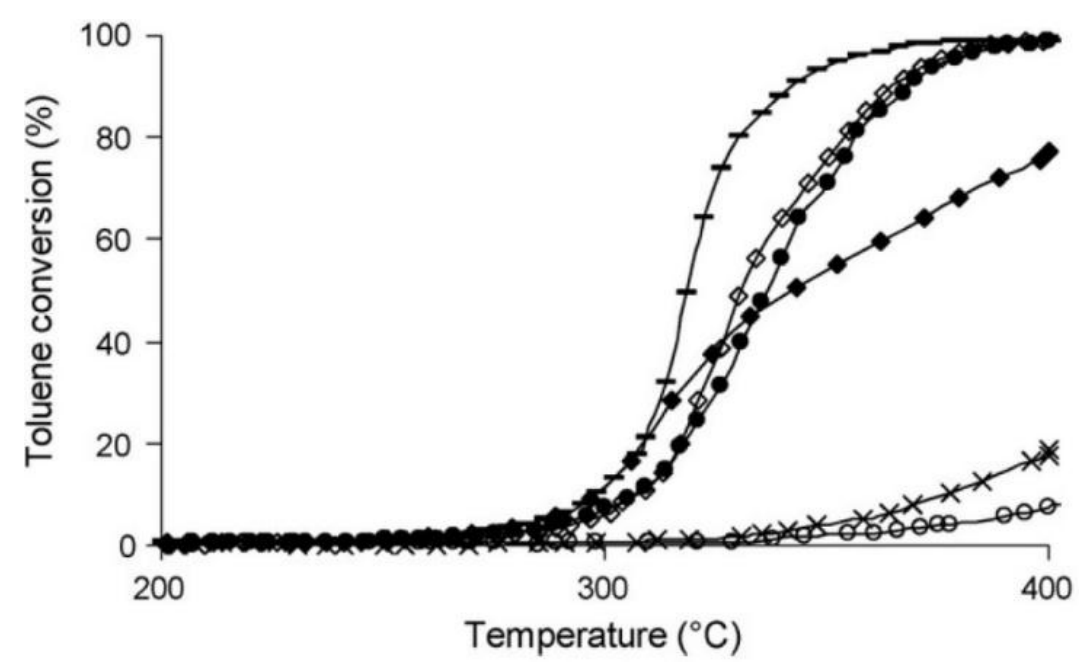

1782 Fig11. Toluene conversion versus temperature for Co-containing hydrotalcites previously 1783 calcined at various temperatures (from Gennequin et al. (2010a)).

Table 6. Synthesis conditions of the LDHs and mixed oxides cited in the part " 2.2 .

Adsorption of aqueous pollutants".

\begin{tabular}{l|l|c|l}
\hline \multicolumn{1}{c|}{ Reference } & Type of material & $\begin{array}{c}\text { Surface area } \\
\left(\mathbf{m}^{2} \cdot \mathbf{g}^{-1}\right)\end{array}$ & \multicolumn{1}{c}{ Synthesis method } \\
\hline $\begin{array}{l}\text { Lehmann et } \\
\text { al. 1999 }\end{array}$ & $\begin{array}{l}\text { Commercial MgAl } \\
\text { LDH (hydrotalcite) }\end{array}$ & 34.8 & Commercial hydrotalcite. \\
\hline $\begin{array}{l}\text { Yang et al. } \\
\mathbf{2 0 0 5}\end{array}$ & Calcined MgAl LDHs & $47-198$ & $\begin{array}{l}\text { Co-precipitation at high } \\
\text { supersaturation, then calcination at } \\
500^{\circ} \mathrm{C} \text { for 4h. }\end{array}$ \\
\hline $\begin{array}{l}\mathbf{L v 0 6} \text { et al. } \\
\mathbf{2 0 0 6}\end{array}$ & $\begin{array}{l}\text { Calcined MgAl, ZnAl, } \\
\text { and NiAl LDHs }\end{array}$ & $39.9-240.6$ & $\begin{array}{l}\text { Synthesis method similar to co- } \\
\text { precipitation with the use of urea, } \\
\text { then calcination at various }\end{array}$ \\
\hline
\end{tabular}




\begin{tabular}{|c|c|c|c|}
\hline & & & temperatures (from 200 to $800^{\circ} \mathrm{C}$ ). \\
\hline $\begin{array}{l}\text { El-Sayed et } \\
\text { al. } 2016\end{array}$ & $\begin{array}{l}\text { Calcined MgAlZn } \\
\text { LDHs }\end{array}$ & 65.1 & $\begin{array}{l}\text { Co-precipitation with } 15 \mathrm{wt} \% \mathrm{Zn} \text {, } \\
\text { then calcination at } 450^{\circ} \mathrm{C} \text { for } 5 \mathrm{~h} \text {. }\end{array}$ \\
\hline $\begin{array}{l}\text { Xue et al. } \\
2016\end{array}$ & Biochar/MgFe LDHs & $\begin{array}{c}3.9 \text { (pores filled } \\
\text { by biochar) }\end{array}$ & $\begin{array}{l}\text { LDH directly synthesized in presence } \\
\text { of the biochar by the liquid-phase } \\
\text { deposition method. }\end{array}$ \\
\hline $\begin{array}{l}\text { Mahmoud } \\
\text { et al. } 2017\end{array}$ & Ti-Fe chitosan LDHs & 146.5 & $\begin{array}{l}\text { Ball milling method for } 10 \mathrm{~h} \text { at } 300 \\
\text { rpm with titanium isopropoxide, iron } \\
\text { nitrate, and chitosan. }\end{array}$ \\
\hline $\begin{array}{l}\text { Yang et al. } \\
2017\end{array}$ & $\begin{array}{l}\mathrm{SiO}_{2} \text { supported on } \\
\mathrm{MgAl} \mathrm{LDHs}\end{array}$ & - & $\begin{array}{l}\text { In situ co-precipitation method at } \\
\text { high supersaturation. }\end{array}$ \\
\hline $\begin{array}{l}\text { Zou et al. } \\
2017\end{array}$ & $\begin{array}{l}\text { Calcined CaMgAl } \\
\text { LDHs }\end{array}$ & $43-157.8$ & $\begin{array}{l}\text { Hydrothermal synthesis, then } \\
\text { calcination at various temperatures } \\
\left(\text { from } 200 \text { to } 600^{\circ} \mathrm{C} \text { ) for } 3 \mathrm{~h} .\right.\end{array}$ \\
\hline $\begin{array}{l}\text { Tzompantzi } \\
\text { et al. } 2011\end{array}$ & Calcined ZnAl LDHs & $155-228$ & $\begin{array}{l}\text { Co-precipitation at low } \\
\text { supersaturation with different } \mathrm{Zn} / \mathrm{Al} \\
\text { molar ratios, then calcination at } \\
400^{\circ} \mathrm{C} \text { for } 12 \mathrm{~h} \text {. }\end{array}$ \\
\hline $\begin{array}{l}\text { Seftel et al. } \\
2015\end{array}$ & $\begin{array}{l}\text { Various LDHs } \\
\text { containing } \mathrm{Zn}^{2+}, \mathrm{Cu}^{2+} \text {, } \\
\mathrm{Al}^{3+}, \mathrm{Fe}^{3+} \text { or } \mathrm{Ti}^{4+}\end{array}$ & $5-230$ & $\begin{array}{l}\text { Co-precipitation at low } \\
\text { supersaturation with various } \\
\mathrm{M}(\mathrm{II}) / \mathrm{M}(\mathrm{III}) \text { molar ratios. }\end{array}$ \\
\hline $\begin{array}{l}\text { Ahmed and } \\
\text { Gasser } 2012\end{array}$ & $\begin{array}{l}\mathrm{MgFe} \mathrm{LDHs} \text { with } \mathrm{Cl}^{-} \\
\text {or } \mathrm{CO}_{3}{ }^{2-} \text { as } \\
\text { compensating anion }\end{array}$ & - & $\begin{array}{l}\text { Separate nucleation and aging } \\
\text { method with colloid mill rotating at } \\
5000 \mathrm{rpm} \text { for } 3 \mathrm{~min} \text {. }\end{array}$ \\
\hline $\begin{array}{l}\text { de Sá et al. } \\
2013\end{array}$ & CaAl LDHs & - & $\begin{array}{l}\text { Co-precipitation at high } \\
\text { supersaturation. }\end{array}$ \\
\hline $\begin{array}{l}\text { Shan et al. } \\
2014\end{array}$ & $\begin{array}{l}\text { Magnetic } \mathrm{Fe}_{3} \mathrm{O}_{4} / \mathrm{MgAl} \\
\text { LDHs }\end{array}$ & 133 & $\begin{array}{l}\text { Co-precipitation at low } \\
\text { supersaturation. }\end{array}$ \\
\hline $\begin{array}{l}\text { Li et al. } \\
2016\end{array}$ & $\mathrm{MgAl} \mathrm{LDHs}$ & $\begin{array}{l}\text { uncalcined : } \\
\qquad 24.7 \\
\text { calcined : } \\
165.1\end{array}$ & $\begin{array}{l}\text { Low temperature ethanol-water } \\
\text { mediated solvothermal method in an } \\
\text { autoclave at } 190^{\circ} \mathrm{C} \text { for } 1 \mathrm{~h} .\end{array}$ \\
\hline
\end{tabular}


(a)

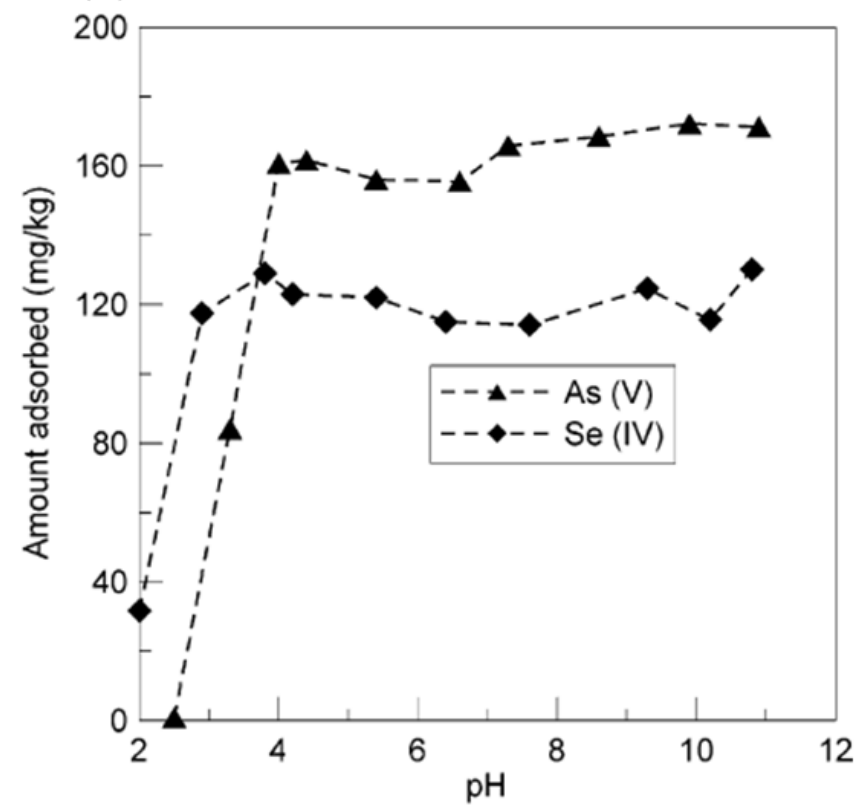

(b)

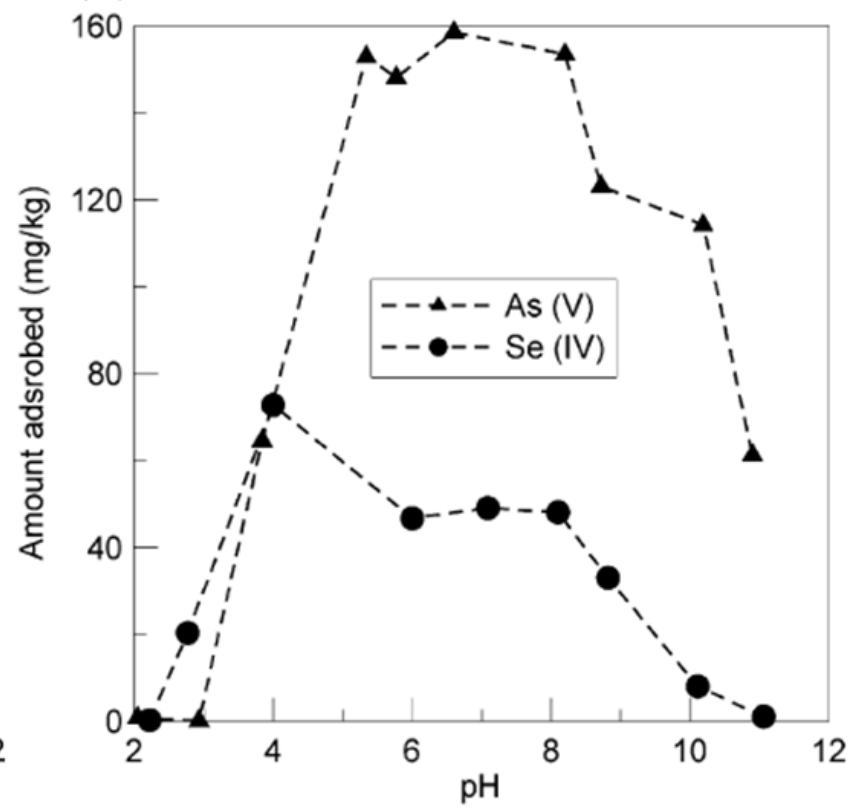

1787

1788 Fig12. Effect of $\mathrm{pH}$ on the uptake of $\mathrm{As}(\mathrm{V})$ and $\mathrm{Se}(\mathrm{IV})$ on (a) calcined and (b) uncalcined 1789 LDHs (from Yang et al. 2005).

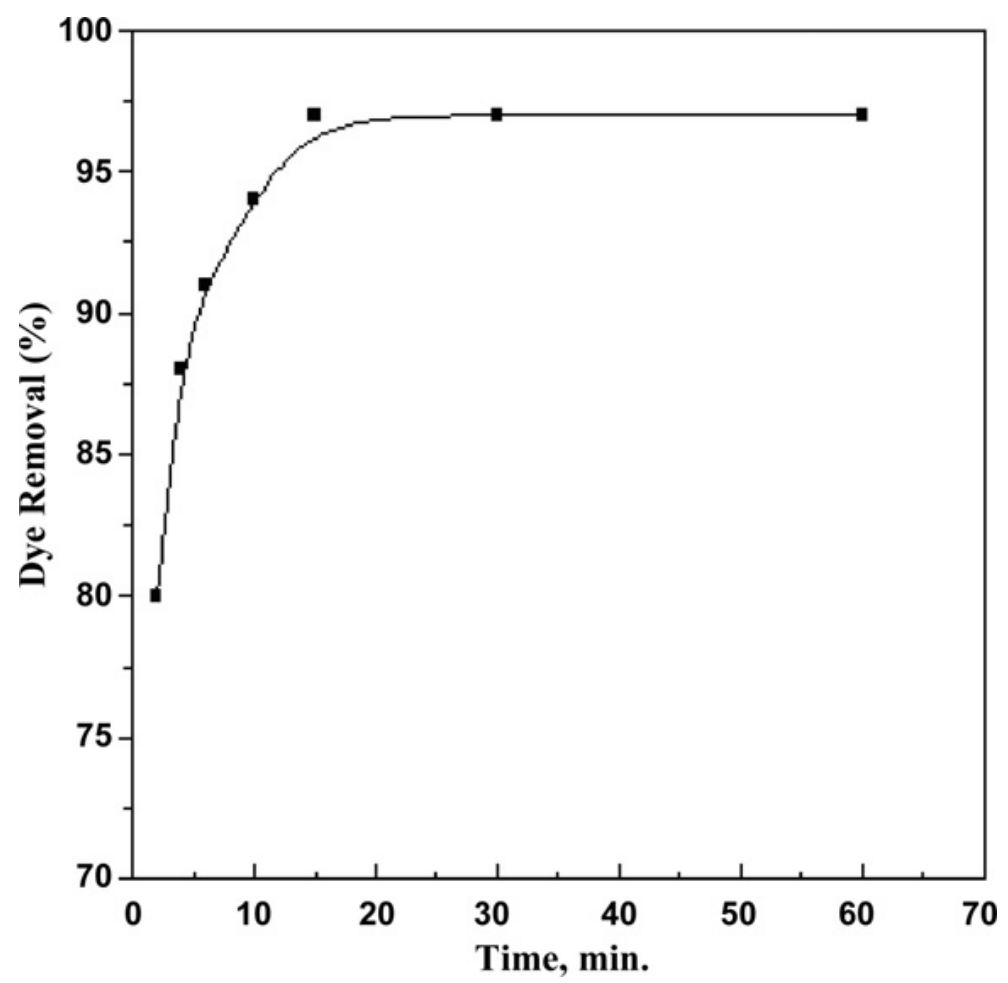


Fig13. Effect of contact time on percentage of dye removal $\mathrm{Mg}-\mathrm{Fe}-\mathrm{CO}_{3}-\mathrm{LDH}$ (from Ahmed and Gasser 2012).

Table 7. Synthesis conditions of the LDHs and mixed oxides cited in the part "2.3.1. Hydrogen production".

\begin{tabular}{|c|c|c|c|}
\hline Reference & $\begin{array}{l}\text { Type of } \\
\text { material }\end{array}$ & $\begin{array}{l}\text { Surface area } \\
\qquad\left(\mathrm{m}^{2} \cdot \mathrm{g}^{-1}\right)\end{array}$ & Synthesis method \\
\hline $\begin{array}{l}\text { Marquevich et } \\
\text { al. } 2001\end{array}$ & $\begin{array}{l}\text { Calcined NiAl } \\
\text { hydrotalcite }\end{array}$ & 104 & $\begin{array}{l}\text { Co-precipitation at high supersaturation, } \\
\text { calcination at } 400^{\circ} \mathrm{C} \text { for } 4 \mathrm{~h} \text {, then reduction } \\
\text { under nitrogen steam at } 600^{\circ} \mathrm{C} \text {. }\end{array}$ \\
\hline $\begin{array}{l}\text { He et al. 2009, } \\
2010\end{array}$ & $\begin{array}{l}\text { Co-NiMgAl } \\
\text { hydrotalcite }\end{array}$ & $\begin{array}{c}\text { uncalcined : } \\
73-144 \\
\text { calcined : } \\
103-180\end{array}$ & $\begin{array}{l}\text { Co-precipitation at high supersaturation and } \\
\text { calcination at } 600^{\circ} \mathrm{C} \text { for } 6 \mathrm{~h} \text {. The metal } \\
\text { loading was fixed at } 40 \% \text { and the Co-Ni } \\
\text { composition was varied from } 40 \text { to } 0,30- \\
10 \text {, to } 20-20,10-30 \text {, and } 0-40 \text {. }\end{array}$ \\
\hline Cesar et al. 2016 & $\begin{array}{l}\mathrm{NiMgAl} \\
\text { hydrotalcite }\end{array}$ & - & $\begin{array}{l}\text { Co-precipitation at low supersaturation and } \\
\text { calcination at } 750^{\circ} \mathrm{C} \text { for } 4 \mathrm{~h} .\end{array}$ \\
\hline $\begin{array}{l}\text { Halabi et al. } \\
\text { 2012a, b }\end{array}$ & $\begin{array}{l}\text { Calcined MgAl } \\
\text { LDHs }\end{array}$ & 15.6 & $\begin{array}{l}\text { Commercial hydrotalcite calcined at } 400^{\circ} \mathrm{C} \\
\text { for } 4 \mathrm{~h} \text { and loaded with } \mathrm{K}_{2} \mathrm{CO}_{3} \text { by dry } \\
\text { impregnation method. }\end{array}$ \\
\hline $\begin{array}{l}\text { Chanburanasiri } \\
\text { et al. } 2013\end{array}$ & MgAl LDHs & 104 & $\begin{array}{l}\text { Commercial } \mathrm{K}_{2} \mathrm{CO}_{3} \text {-promoted hydrotalcite } \\
\text { in cylindrical shape. }\end{array}$ \\
\hline Ashok et al. 2008 & $\begin{array}{l}\text { Calcined } \\
\text { NiCuAl LDHs }\end{array}$ & $120-182$ & $\begin{array}{l}\text { Co-precipitation at low supersaturation and } \\
\text { calcination at } 450^{\circ} \mathrm{C} \text { for } 5 \mathrm{~h} \text {. Atomic ratio } \\
\text { between divalent }\left(\mathrm{Ni}^{2+}+\mathrm{Cu}^{2+}\right) \text { and trivalent } \\
\left(\mathrm{Al}^{3+}\right) \text { cations varied from } 2 \text { to } 9 \text { but } \\
\text { constant nickel metal content. }\end{array}$ \\
\hline $\begin{array}{l}\text { García-Sancho } \\
\text { et al. } 2017\end{array}$ & $\begin{array}{l}\text { Calcined } \\
\text { NiMgAl LDHs }\end{array}$ & $69-156$ & $\begin{array}{l}\text { Co-precipitation at low supersaturation in } \\
\text { presence of urea, and calcination at } 850^{\circ} \mathrm{C} \\
\text { for } 10 \mathrm{~h} \text {. }\end{array}$ \\
\hline $\begin{array}{l}\text { Sikander et al. } \\
2018\end{array}$ & $\begin{array}{l}\text { Calcined } \\
\text { NiMgAl LDHs }\end{array}$ & - & $\begin{array}{l}\text { Co-precipitation at low supersaturation, and } \\
\text { calcination at different temperatures: } 550 \text {, } \\
700 \text {, and } 800^{\circ} \mathrm{C} \text { for } 6 \mathrm{~h} \text {. }\end{array}$ \\
\hline
\end{tabular}



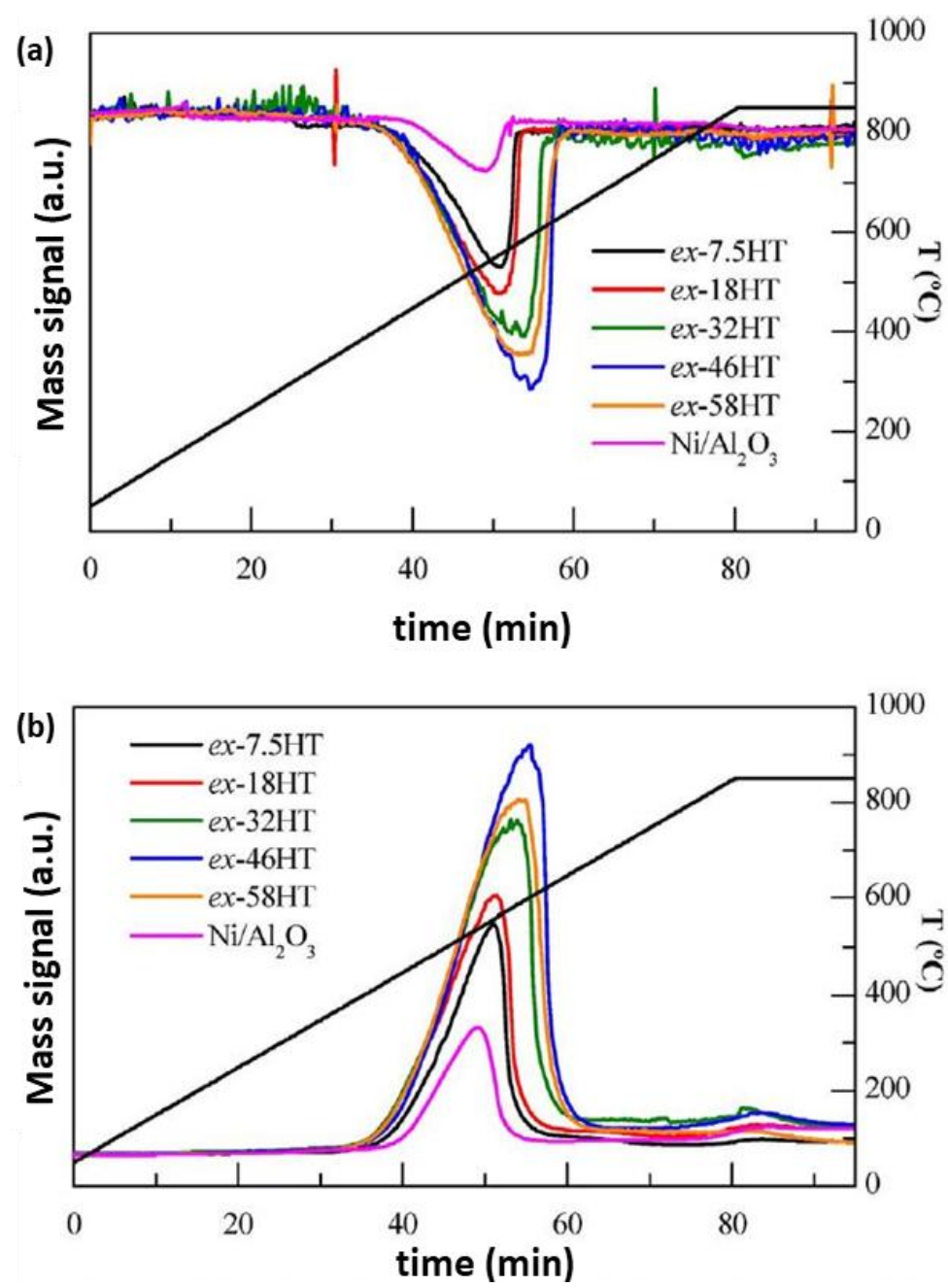

1797 Fig14. Temperature-programmed methane conversion (a) and hydrogen production (b) by 1798 nickel-containing calcined hydrotalcites (from García-Sancho et al. 2017).

Table 8. $\mathrm{H}_{2}$ production by several types of hydrotalcite-based materials.

\begin{tabular}{c|c|c|c|c|c}
\hline $\begin{array}{c}\text { M(II)/M(III) } \\
\text { molar ratio }\end{array}$ & $\begin{array}{c}\text { Conversion } \\
\mathbf{( \% )}\end{array}$ & $\begin{array}{c}\text { Selectivity } \\
\mathbf{( \% )}\end{array}$ & $\begin{array}{c}\text { Synthesis } \\
\text { method }\end{array}$ & Source & References \\
\hline $\mathbf{2}$ & $20-79.7$ & $66.6-72.1$ & $\begin{array}{c}\text { Co- } \\
\text { precipitation }\end{array}$ & $\begin{array}{c}\text { Sunflower } \\
\text { oil }\end{array}$ & $\begin{array}{c}\text { Marquevich et al. } \\
\mathbf{2 0 0 1}\end{array}$ \\
\hline $\mathbf{3}$ & 62 & 70 & $\begin{array}{c}\text { Co- } \\
\text { precipitation }\end{array}$ & Ethanol & He et al. 2009 \\
\hline
\end{tabular}




\begin{tabular}{c|c|c|c|c|c}
\hline - & 100 & 70 & $\begin{array}{c}\text { Co- } \\
\text { precipitation }\end{array}$ & Ethanol & de Souza et al. 2012 \\
\hline $\mathbf{1 . 5 6}$ & $72-99.6$ & $91.3-99.8$ & Commercial & Methane & Halabi et al. 2012b \\
\hline $\mathbf{1}$ & $49-94$ & $56.1-96.5$ & $\begin{array}{c}\text { Co- } \\
\text { precipitation }\end{array}$ & $\begin{array}{c}\text { Ethylene } \\
\text { glycol }\end{array}$ & Cesar et al. 2016 \\
\hline $\begin{array}{c}\text { M(II)/M(III) } \\
\mathbf{m o l a r} \text { ratio }\end{array}$ & $\begin{array}{c}\text { Conversion } \\
\mathbf{( \% )}\end{array}$ & $\begin{array}{c}\mathbf{H}_{\mathbf{2}} \text { produced } \\
\text { (a.u.) }\end{array}$ & $\begin{array}{c}\text { Synthesis } \\
\text { method }\end{array}$ & Source & References \\
\hline $\mathbf{3}$ & $15-55$ & $246-1253$ & $\begin{array}{c}\text { Urea }+ \text { co- } \\
\text { precipitation }\end{array}$ & Methane & $\begin{array}{c}\text { García-Sancho et al. } \\
\mathbf{2 0 1 7}\end{array}$ \\
\hline $\mathbf{3}$ & $15-40$ & $250-1100$ & $\begin{array}{c}\text { Urea }+ \text { co- } \\
\text { precipitation }\end{array}$ & Methane & $\begin{array}{c}\text { García-Sancho et al. } \\
\mathbf{2 0 1 8}\end{array}$ \\
\hline
\end{tabular}
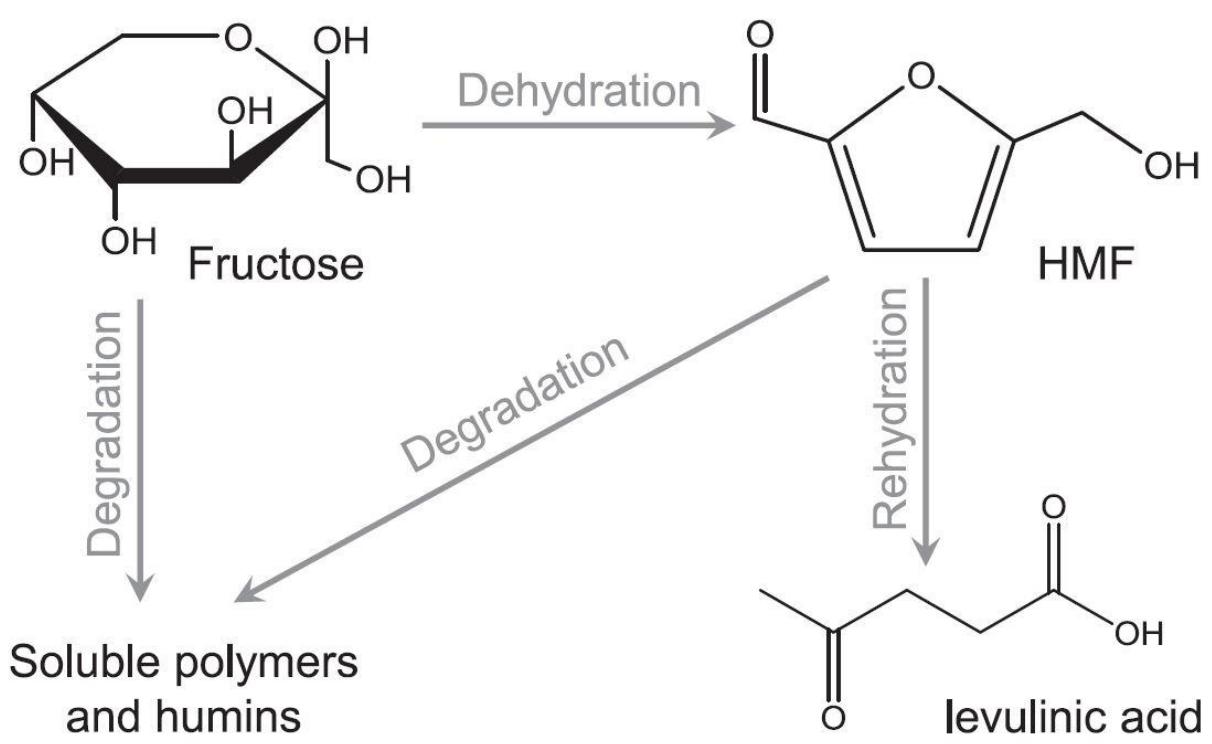

HMF

Fig15. Scheme of the reactions involved in fructose dehydration and the resulting formation of 5-HMF and byproducts (from Dou et al. 2018).

Table 9. Synthesis parameters of the lamellar materials cited in the part "2.3.2. 5Hydroxymethylfurfural formation".

\begin{tabular}{c|c|c|c}
\hline Reference & Type of material & $\begin{array}{c}\text { Surface area } \\
\left(\mathrm{m}^{2} \cdot \mathrm{g}^{-1}\right)\end{array}$ & Synthesis method \\
\hline
\end{tabular}




\begin{tabular}{|c|c|c|c|}
\hline $\begin{array}{l}\text { Lourvanij and } \\
\text { Rorrer } 1994\end{array}$ & $\begin{array}{l}\text { Pillared Na- } \\
\text { montmorillonite }\end{array}$ & $137.7-249.6$ & $\begin{array}{l}\text { Na-montmorillonite mixed into the } \\
\text { pillaring agent solution. }\end{array}$ \\
\hline Fang et al. 2014 & $\begin{array}{l}\text { Cr-montmorillonite } \\
\text { K10 }\end{array}$ & - & $\begin{array}{l}\text { K-10 montmorillonite exchanged } \\
\text { with Cr cations. }\end{array}$ \\
\hline $\begin{array}{l}\text { Chheda and } \\
\text { Dumesic } 2007\end{array}$ & $\begin{array}{l}\text { Calcined } \mathrm{MgAl} \mathrm{LDH} \text {, } \\
\mathrm{MgO} / \mathrm{ZrO}_{2} \\
\text { andMgO/TiO }\end{array}$ & $\sim 300$ & $\begin{array}{l}\text { MgAl LDH synthesized by co- } \\
\text { precipitation at low supersaturation, } \\
\text { and mixed oxides by sol-gel method. } \\
\text { All these samples have been clacined } \\
\text { at } 450^{\circ} \mathrm{C} \text { for } 8 \mathrm{~h} \text {. }\end{array}$ \\
\hline Li et al. 2011 & Calcined NiMgAl LDH & $34-117$ & $\begin{array}{l}\text { Co-precipitation at low } \\
\text { supersaturation with varying } \mathrm{Ni} \text { at } \% \text {, } \\
\text { and calcination at } 800^{\circ} \mathrm{C} \text { for } 5 \mathrm{~h} .\end{array}$ \\
\hline $\begin{array}{l}\text { Zeng et al. } \\
\text { 2009b }\end{array}$ & Calcined AlZr LDHs & $66-281$ & $\begin{array}{l}\text { Co-precipitation at high } \\
\text { supersaturation and calcination at } \\
500^{\circ} \mathrm{C} \text { for } 6 \mathrm{~h} \text {. }\end{array}$ \\
\hline
\end{tabular}

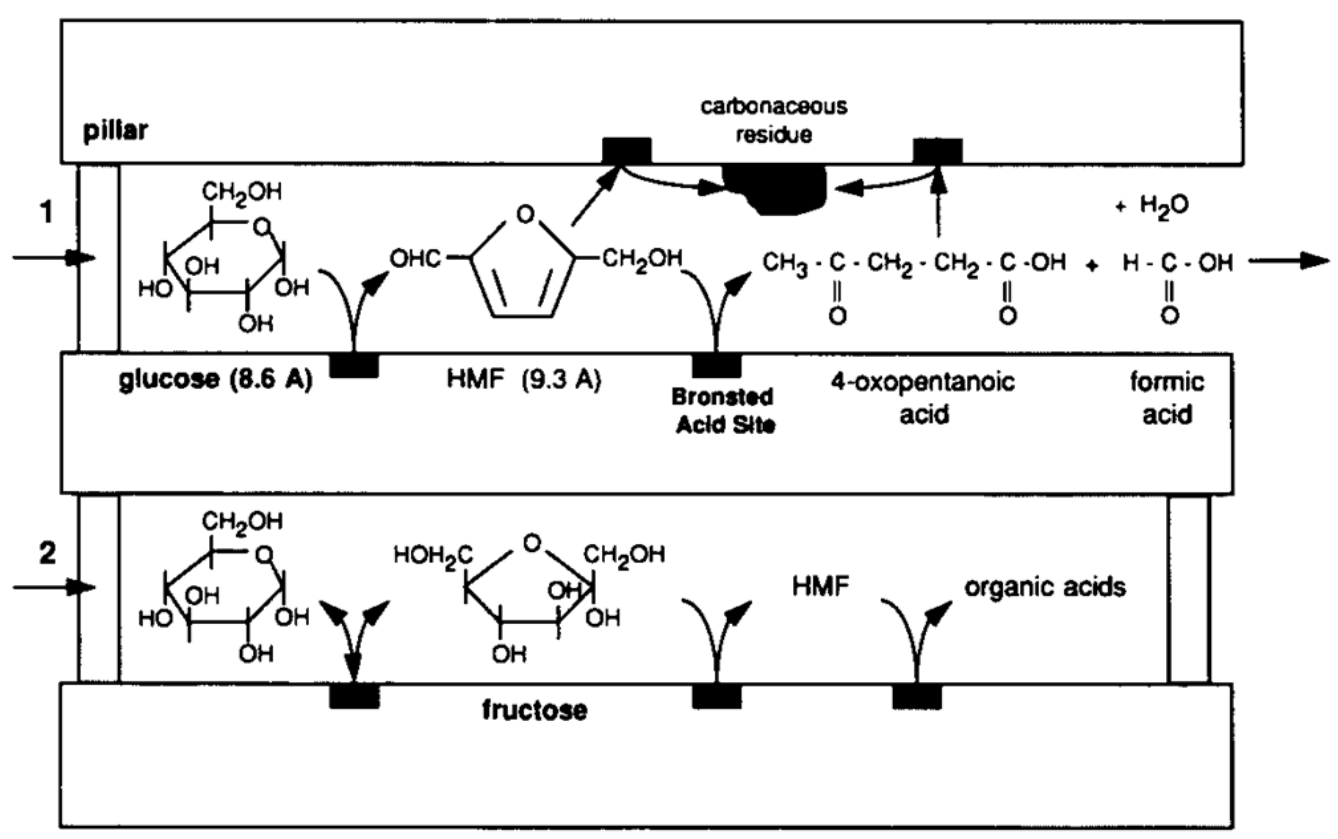

montmorillonite clay layer (9.4 A)

1809 Fig16. Proposed intraparticle diffusion and reaction scheme for glucose and fructose within a pillared clay catalyst. Reaction 1: sequential dehydration of glucose to HMF and organic acid.

1811 Reaction 2: isomerization of glucose to fructose. (from Lourvanij and Rorrer 1994). 


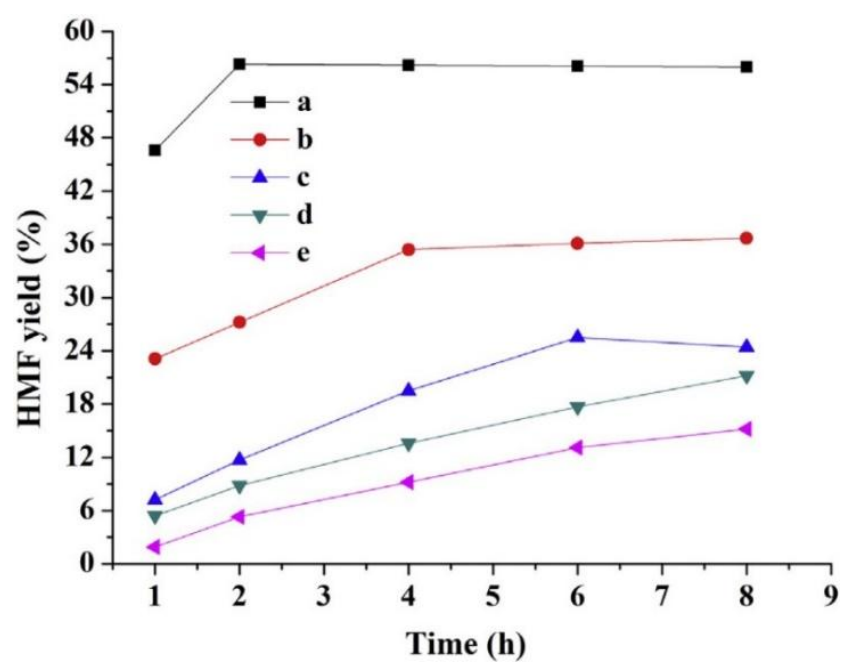

1812

1813 Fig17. Catalytic conversion of glucose into 5-HMF at various [BMIM]Cl concentrations in 1814 DMSO, e = DMSO only (from Fang et al. 2014). 


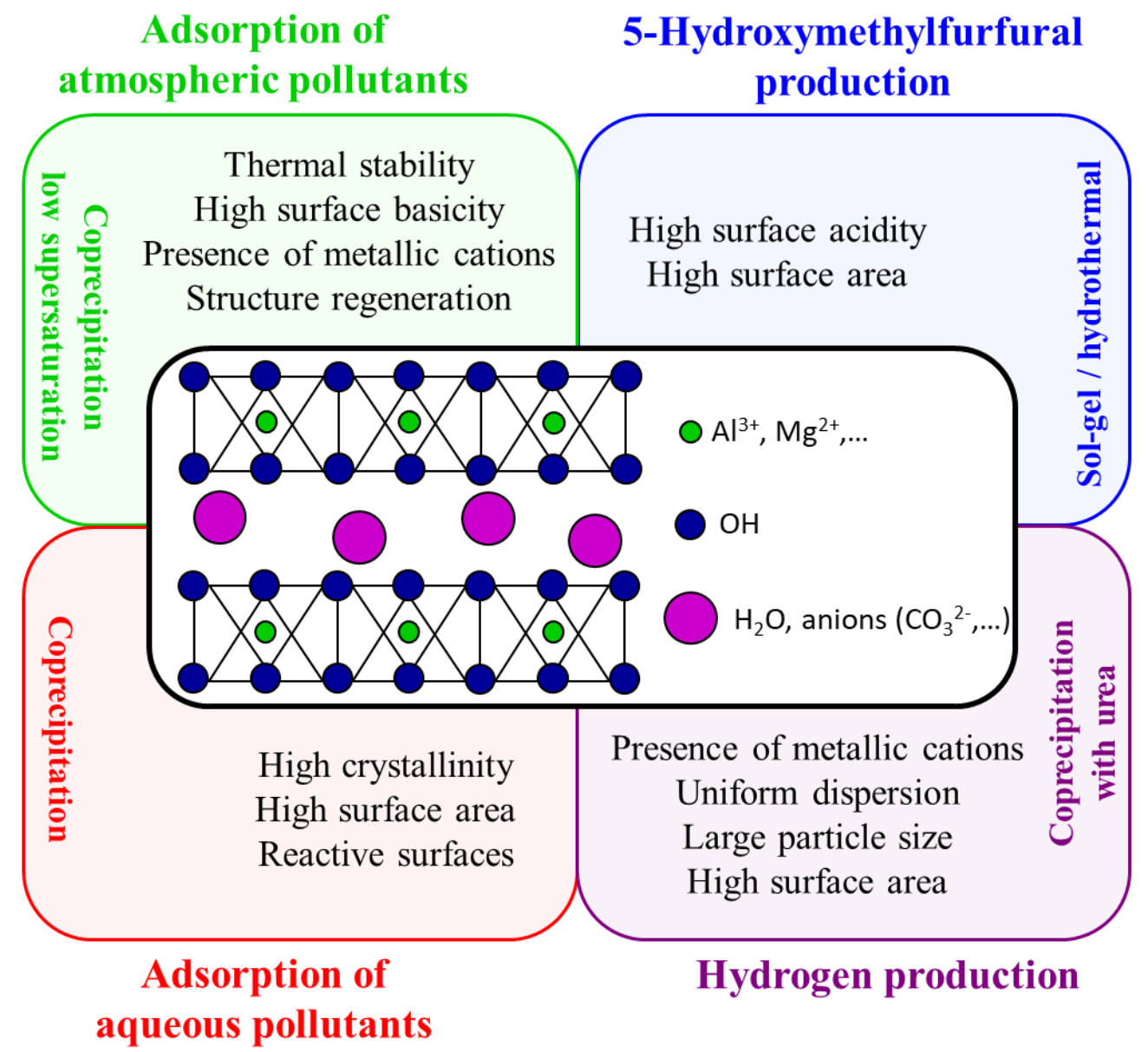

1816 Fig18. Relations between structural properties and applications of hydrotalcites and related 1817 materials 